Nilda Mercedes Cabrera Pasca

\title{
Three Essays in Macroeconomics
}

Thesis presented to the Postgraduate Program in Economic of the Departamento de Economia, PUC-Rio as partial fulfillment of the requirements for the degree of Doutor em Economia

Advisor : Prof. Carlos Viana de Carvalho

Co-Advisor: $\quad$ Prof. Eduardo Zilberman 


\section{Nilda Mercedes Cabrera Pasca}

\section{Three Essays in Macroeconomics}

Thesis presented to the Postgraduate Program in Economic of the Departamento de Economia, PUC-Rio as partial fulfillment of the requirements for the degree of Doutor em Economia. Approved by the following commission:

Prof. Carlos Viana de Carvalho

Advisor

Departamento de Economia - PUC-Rio

Prof. Eduardo Zilberman

Co-Advisor

Departamento de Economia - PUC-Rio

Prof. Tiago Couto Berriel

Departamento de Economia - PUC-Rio

Prof. Juliano Junqueira Assunção

Departamento de Economia - PUC-Rio

Prof. Sergio A. Lago Alves

Banco Central do Brasil

Prof. Cezar Santos

Departamento de Economia - EPGE-FGV

Prof. Mônica Herz

Coordinator of the Social Science Center - PUC-Rio

Rio de Janeiro - September 10, 2014 
All rights reserved.

\section{Nilda Mercedes Cabrera Pasca}

Nilda Pasca graduated from the National University of San Agust Ân Arequipa - Peru, and MA in Economics from Federal University of Rio Grande do Sul, and now a doctorate degree in economics from PUC-Rio.

Bibliographic data

Pasca, Nilda

Three Essays in Macroeconomics / Nilda Mercedes Cabrera Pasca ; advisor: Carlos Viana de Carvalho; co-advisor: Eduardo Zilberman. - 2014.

80 f. : il. ; $30 \mathrm{~cm}$

Tese (Doutorado em Economia)-Pontifícia Universidade Católica do Rio de Janeiro, Rio de Janeiro, 2014.

Inclui bibliografia

1. Economia - Teses. 2. Expansão de Crédito; Fricções financeiras; Crédito Consignado; Desigualdade de Renda; Famílias heterogêneas; Mercados incompletos; Política monetária; Preços das commodities; FAVAR. I. Viana de CarvaIho. II. Zilberman. III. Pontifícia Universidade Católica do Rio de Janeiro. Departamento de Economia. IV. Título. 
To my beloved parents, sisters and brother. 


\section{Acknowledgments}

Aos meus orientadores Professores Carlos Viana de Carvalho e Eduardo Zilberman pelos ensinamentos, paciência e estímulos para a realização desta pesquisa. Muito Obrigada.

Aos professores do departamento, pelos seus ensinamentos que contribuíram valiosamente com minha formação do doutorado.

Aos meus amados pais, Gabriel e Eufemia, que apesar da distância, sempre estiveram muito perto de mim. Obrigada por tudo.

Às minhas irmãs e ao meu irmão pelo carinho, amor e por sua compressão por tantos momentos de ausência.

Aos meus colegas e amigos da PUC-Rio pela amizade e apoio em tantos momentos vividos durante estes anos, em especial pela convivência na favelinha. A Guilherme Hirata, Rafael Cayres e Joana Costa pela sua amizade e apoio em todos os momentos. Em especial a Laura Souza pela sua amizade, apoio e parceria.

Aos funcionários do departamento pelo apoio durante todo o curso.

À Capes, CNPq e à PUC-Rio pelos auxílios financeiros concedidos, sem os quais este trabalho não poderia ser concluído. 


\section{Abstract}

Pasca, Nilda; Viana de Carvalho (Advisor); Zilberman (Co-advisor). Three Essays in Macroeconomics. Rio de Janeiro, 2014. 80p. PhD Thesis - Departamento de Economia, Pontifícia Universidade Católica do Rio de Janeiro.

This thesis is comprised of three articles independent related to macroeconomics. In the first article, we augment a relatively standard dynamic, general equilibrium model with financial frictions, in order to quantify the macroeconomic effects of the credit deepening process observed in Brazil. In the model, a stylized banking sector intermediates credit from patient households to impatient households and firms. The key novelty of the paper is to model the credit constraint faced by (impatient) households as a function of future labor income. In the calibrated model, credit deepening generates only modest above-trend growth in consumption, investment, and GDP. In the second article, we documented that the association between consumption growth and credit expansion is stronger in countries with higher income inequality. We use an incomplete markets model with heterogeneous households, idiosyncratic risk and borrowing constraints to check in which extent this theoretical framework can rationalize the empirical finding. We show that when the source of income inequality comes from households' lowest fixed level of human capital, our model can rationalize the empirical evidence. Once other sources of income inequality are considered, the opposite occurs. Finally, in the third article, we use a Factor-Augmented Vector Autoregressive (FAVAR) model to estimate the impact of an international interest rate shock and a commodities price shock on the Peruvian economy. Our results suggest that a positive international interest rate shock has contractive effects, it reduces GDP and inflation rate and generates an exchange rate depreciation, an increase of the domestic interest rate and a reduction of international reserves. In the case of commodity price shock, we find that its effects are consistent with the previous literature in which a positive shock expands GDP, net exports and inflation rate.

\section{Keywords}

Credit Deepening; Financial Frictions; payroll lending; Income Inequality; Heterogeneous households; Incomplete Markets; Monetary Policy; Commodity prices; FAVAR . 


\section{Resumo}

Pasca, Nilda; Viana de Carvalho (Orientador); Zilberman (Coorientador). Três Ensaios em Macroeconomia. Rio de Janeiro, 2014. 80p. Tese de Doutorado — Departamento de Economia, Pontifícia Universidade Católica do Rio de Janeiro.

Esta tese é composta por três artigos independentes relacionados à macroeconomia. No primeiro artigo, nós aumentamos um modelo dinâmico de equilíbrio geral relativamente padrão com fricções financeiras, a fim de quantificar os efeitos macroeconômicos da expansão de credito observado no Brasil. No modelo, um estilizado setor bancário intermedia credito das famílias pacientes para as famílias impacientes e empresas. A novidade fundamental deste artigo é que nós modelamos a restrição de crédito enfrentada por (impacientes) famílias em função do rendimento do trabalho futuro. No modelo calibrado, expansão de crédito gera apenas modestos resultados sobre o crescimento acima do potencial do consumo, investimento e PIB. No segundo artigo, documentamos que a associação entre o crescimento do consumo médio per capita e a expansão do crédito é mais forte em países com maior desigualdade de renda. Nós usamos um modelo de mercados incompletos com famílias heterogêneas, risco idiossincrático e restrições ao crédito para verificar em que medida este arcabouço teórico pode racionalizar a evidencia empírica. Mostramos que, quando a fonte de desigualdade de renda vem do menor nível de capital humano fixo das famílias, o nosso modelo pode racionalizar a evidência empírica encontrada. Uma vez que as outras fontes de desigualdade de renda consideradas, o resultado oposto corre. Finalmente, no terceiro artigo, nós usamos um modelo de vetor auto-regressivo com fator aumentado (FAVAR) para estimar o impacto de um choque na taxa de juros internacional e de choque de preços de commodities na economia peruana. Nossos resultados sugerem que um choque positivo de taxa de juros internacional tem efeitos contracionistas, reduzindo o PIB, a taxa de inflação e gerando uma depreciação cambial, aumentando a taxa de juros interna e uma redução das reservas internacionais. No caso de choque de preços de commodities, encontramos que os nossos resultados são consistentes com a literatura, em que um choque positivo expande o PIB, as exportações líquidas e taxa de inflação.

\section{Palavras-chave}

Expansão de Crédito; Friç̧ões financeiras; Crédito Consignado; Desigualdade de Renda; Famílias heterogêneas; Mercados incompletos; Política monetária; Preços das commodities; FAVAR. 


\section{Contents}

1 Macroeconomic Effects of Credit Deepening in Brazil ${ }^{1} \quad 12$

$\begin{array}{ll}1.1 \text { Introduction } & 12\end{array}$

$\begin{array}{ll}1.2 & \text { Brief review of the literature } \\ 1.3 & 16\end{array}$

$\begin{array}{lll}1.3 & \text { The analytical framework } & 17\end{array}$

1.4 Quantitative analysis 23

$\begin{array}{ll}1.5 \text { Conclusion } & 37\end{array}$

2 Consumption Boom and Credit Deepening: The Role of Inequality ${ }^{2} \quad 39$

$\begin{array}{lll}2.1 & \text { Introduction } & 39\end{array}$

2.2 Empirical Evidence 40

2.3 Model 45

2.4 Quantitative analysis 49

$\begin{array}{ll}2.5 \text { Conclusion } & 57\end{array}$

3 Impact of foreign shocks on small open economy: A FAVAR approach for Peru $\quad 59$

$\begin{array}{lll}3.1 & \text { Introduction } & 59\end{array}$

3.2 Literature review 61

$\begin{array}{lll}3.3 & \text { Methodology } & 61\end{array}$

$\begin{array}{lll}3.4 & \text { Data } & 64\end{array}$

3.5 Results for the foreign block US economy 66

3.6 Results for the foreign block with the major trading partners of Peru $\quad 70$

3.7 Conclusions 72

$4 \begin{array}{ll}4 & \text { References }\end{array}$

A Results for the foreign block U.S. economy 79

${ }^{2}$ This is a joint work with Laura Souza. 


\section{List of Figures}

1.1 Nonearmarked credit outstanding to GDP ratio in Brazil, by borrower type. Nonearmarked credit is the nominal outstanding balance of credit operations by the National Financial System. Nonearmarked funds refer to financing and loans in which rates and destination are freely negotiated between financial institutions and borrowers, i.e. the financial institution has autonomy to decide in which economic sectors it will apply the funds raised in the market through time deposits, by Bank Certificates of Deposit (CDB), funds raised in foreign markets, part of demand deposits, among other instruments. Source: Central Bank of Brazil, available at www.bcb.gov.br.

1.2 Ratio of households nonearmarked credit outstanding to GDP in Brazil, by type. Collateralized credit consists of vehicles financing, other goods financing and mortgages. Non-collateralized credit consists of credit card, personal credit, overdraft and other nonearmarked credit instruments that were not classified in previous types of credit. Source: Brazilian Central Bank, available at www.bcb.gov.br.

1.3 Credit deepening experiment: evolution of $\tau_{t}^{K}, \tau_{t}^{W L}$ and $\tau_{t}^{S}$.

1.4 Credit deepening experiment: credit variables (model and data). See notes in Figure 1.1 and 1.2 on how these credit variables are constructed.

1.5 Credit deepening experiment: macro variables (model).

1.6 Credit deepening experiment: consumption, investment and stocks.

1.7 Credit deepening experiment: labor market outcomes.

1.8 Credit deepening experiment: financial market outcomes. The spread is calculated using the SELIC rate, which is the overnight rate in the interbank market targeted by monetary policy, and the Brazilian prime rate, which averages interest rates on loans made to firms that are considered preferential borrowers. For more details on the computation of the Brazilian prime rate, see www.bcb.gov.br/pec/depep/spread/REBC_2011.pdf. Source: Brazilian Central Bank, available at www.bcb.gov.br.

1.9 Credit deepening experiment: ratio of household debt to annual income. Household debt considers only non-earmarked funds held by financial institutions. Annual income is disposable income accumulated over the past twelve months. Source: Central Bank of Brazil, available at www.bcb.gov.br.

1.10 Sensitivity analysis: $\beta^{e}$ and $\beta^{i}$.

1.11 Sensitivity analysis: $\gamma$.

1.12 Sensitivity analysis: $\eta$.

1.13 Credit deepening experiment (non-smooth): credit variables (data and model). 
1.14 Credit deepening experiment (non-smooth): macro variables (model).

1.15 Impulse response functions for selected variables to a technology shock.

1.16 Impulse response functions for selected variables to a monetary policy shock.

2.1 Optimal Consumption and Assets Holdings at $s=s_{5}$ and $\theta_{1}=1 \quad 51$

2.2 High and Low $\theta_{1} \quad 53$

2.3 High and Low income uncertainty 54

2.4 High and Low transfer and tax 56

3.1 Shows the response of the Peruvian economy to a 25 basis points increase of foreign monetary shock IRF. The variables are represented in monthly growth (percentage change), except for the interest rates.

3.2 Shows the response of the Peruvian economy to a shock of one standard deviation in the commodity factor - IRF. The variables are represented in monthly growth (percent change), except the interest rates.

3.3 Shows the response of the Peruvian economy to a 25 basis points increase of foreign monetary shock IRF. The variables are represented in monthly growth (percentage change), except for the interest rates.

3.4 Shows the response of the Peruvian economy to a shock of one standard deviation in the commodity factor - IRF. The variables are represented in monthly growth (percent change), except the interest rates.

4.1 Shows the response of the Peruvian economy to a 25 basis points increase of foreign monetary shock IRF. The variables are represented in monthly growth (percent change), except the interest rates.

4.2 Shows the response of the Peruvian economy to a 25 basis points increase of foreign monetary shock IRF. The variables are represented in monthly growth (percent change), except the interest rates. 


\section{List of Tables}

1.1 Calibration. See Section 1.4.1 for details.

1.2 Credit deepening experiment: comparison with the data. Growth rates between 2004 and 2012. Data on GDP, consumption and investment in capital are obtained from National Accounts, available at www.ipeadata.gov.br.

2.1 Results - Summary of main results 40

2.2 Empirical Evidence 44

2.3 Benchmark economy - Brazil 50

2.4 Case 1 - Shares of households in debt at each economy divided by $\theta_{i} 53$

2.5 Case 2 - Shares of households in debt at each economy divided by $\theta_{i} 55$

2.6 Case 3 - Shares of households in debt at each economy divided by $\theta_{i} 57$

3.1 Variance Decomposition at the 30-month horizon. 68 


\section{Macroeconomic Effects of Credit Deepening in Brazil ${ }^{1}$}

\section{1}

\section{Introduction}

In the last ten years, many developing countries experienced a process often referred to as "credit deepening", during which measures of credit usage in the economy increase markedly. ${ }^{2}$ In Brazil, this was not different. Figure 1.1 plots the ratio of nonearmarked credit outstanding to GDP by borrower type. It shows that, during the 2000s, Brazil has experienced a large expansion of credit to households and to corporations. For this reason, credit deepening is often cited as a source that contributed to economy growth in Brazil. For example, governor Tombini (June 2012) said: ${ }^{3}$

"The domestic demand continues to be the support of the economy, household consumption has been stimulated by moderate credit expansion and by the generation of jobs and income."

Moreover, deputy governor Araújo (August 2012) said: ${ }^{4}$

"There is space for credit expansion. In addition to be possible, the continuity of credit market expansion is desirable, given its importance for Brazil to experience in the coming years a sustainable and lasting growth cycle.".

However, these arguments are not accompanied by any empirical evidence or theoretical formalization. In this paper we use a relatively standard new Keynesian dynamic general equilibrium model, augmented with financial frictions, to address this question.

In the model, a stylized banking sector intermediates credit from patient households to impatient households and firms. While we borrow from several contributions available in the literature, one feature of our model is, to

\footnotetext{
${ }^{1}$ This is a joint work with Laura Souza.

${ }^{2}$ For example, domestic credit to the private sector to GDP ratio, in India, went from $32 \%$ in 2002 to $51 \%$ in 2011. In Latin America, we can mention Colombia. In 2011, its ratio of domestic credit to the private sector to GDP was $45 \%$, but, in 2002, it was only $25 \%$.

${ }^{3}$ Source:http://veja.abril.com.br/noticia/economia/pib-indica-continuidade-darecuperacao-diz-tombini

${ }^{4}$ Source:http://g1.globo.com/economia/noticia/2012/08/ainda-ha-espaco-paraexpansao-do-credito-no-brasil-diz-diretor-do-bc.html
} 


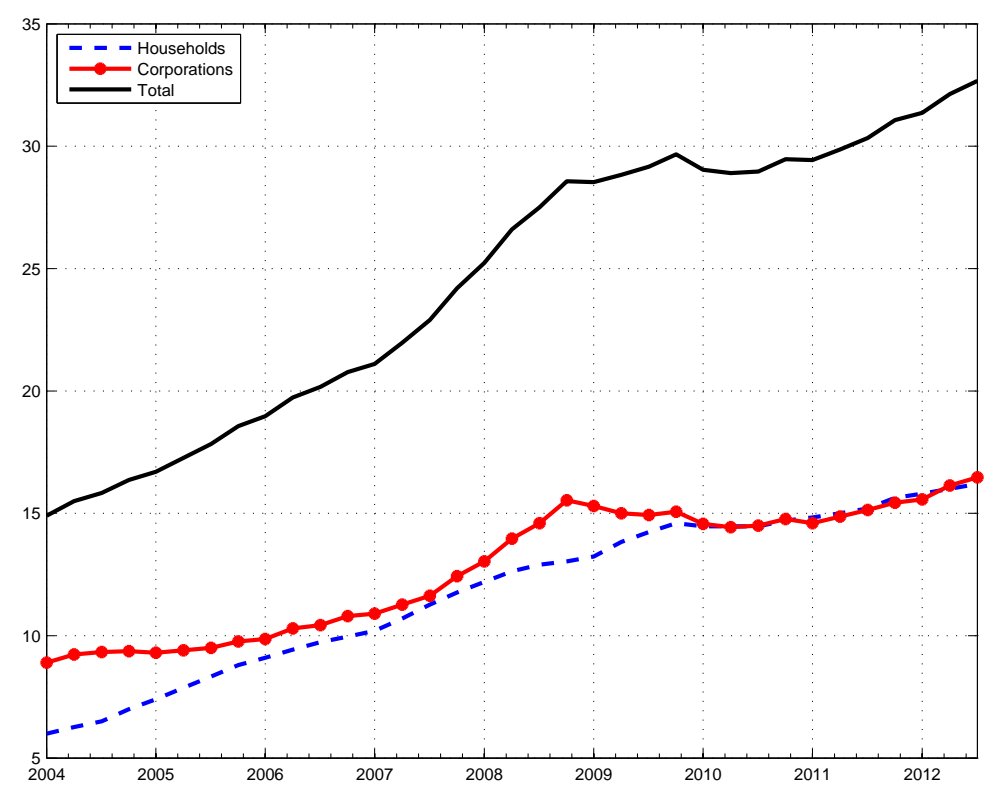

Figure 1.1: Nonearmarked credit outstanding to GDP ratio in Brazil, by borrower type. Nonearmarked credit is the nominal outstanding balance of credit operations by the National Financial System. Nonearmarked funds refer to financing and loans in which rates and destination are freely negotiated between financial institutions and borrowers, i.e. the financial institution has autonomy to decide in which economic sectors it will apply the funds raised in the market through time deposits, by Bank Certificates of Deposit (CDB), funds raised in foreign markets, part of demand deposits, among other instruments. Source: Central Bank of Brazil, available at www.bcb.gov.br.

our knowledge, novel. Specifically, we model the credit constraint faced by (impatient) households as a function of future labor income. ${ }^{5}$ We do so motivated by the Brazilian experience, which featured a sizeable increase in household credit that was not associated with purchases of real estate or other collaterilizable assets (e.g., durable goods). In Brazil, an important factor behind the credit expansion was the emergence of the so-called consignado credit ("payroll lending"), whereby creditors are paid straight out of debtors' paychecks. Such lending is thus not collateralized by an asset, but by some valuation of future labor income.

Although our modeling of consignado credit is very stylized, we believe

${ }^{5}$ Mendoza (2002) develops a model in which a fraction of consumption has to be financed with current income. While his assumption leads to a debt limit that depends on current labor income, this is fundamentally different from a limit based on future labor income, which arises because creditors are repaid out of debtors' future paychecks. The paper that comes closest to ours in terms of motivation for the credit limit based on future labor income is Carvalho et al. (2013). They propose a model of risky lending to households, in which, upon default, creditors can seize a fraction of the debtor's labor income. In contrast, we rely on the fact that payroll lending in Brazil involves one of the lowest risks of non-performance to abstract from default in these operations. Our papers were developed in parallel, and independently from one another. 
this is an important feature of the Brazilian credit deepening process that we should try to capture in our analysis, because it might be a useful reducedform way to account for credit frictions in other economies in which noncollateralized credit was an important part of the credit expansion process. ${ }^{6}$

Another important institutional change that spurred the credit deepening process in Brazil was a change in lending practices backed by a new law that allowed autos to be kept as property of creditors until the associated loans had been fully repaid. Before this law, a car could be used as collateral for the loan obtained to finance its purchase, but upon default judges often ruled against creditors seizing the collateral. As a result, that market was relatively underdeveloped and credit was expensive. Besides household credit, lending to firms also increased significantly in the last decade in Brazil (Figure 1.1).

We calibrate the model to replicate the credit deepening process witnessed in Brazil since 2004. In particular, we require our model to match the credit expansion for both firms and households - including both noncollateralized and collateralized credit in the latter case (Figure 1.2). ${ }^{7}$ While our model has features that allow for an endogenous response of credit to economic developments (such as "valuation effects" in the credit constraints that we impose on borrowers), we essentially match the path of the various credit measures over GDP by calibrating three time-varying parameters that dictate the tightness of the credit constraints in the model. This is consistent with the idea that a large fraction of the credit expansion was due to reforms and "innovations" (such as the spreading of consignado credit) that fueled the credit deepening process.

According to our calibrated model, the aggregate effects of the credit deepening process witnessed in Brazil are relatively small in absolute terms. Credit deepening increased GDP by only 1.8\% between 2004 and 2012 (that is, an annual growth rate of 0.2 percent). During the same period, consumption and investment increased by 1 and 3 percent, respectively. These results come about despite the fact that our calibration favors the hypothesis that such a credit deepening process can boost economic growth temporarily.

However, because our model does not feature trend growth, in order to assess the importance of credit deepening for the Brazilian growth experience between 2004 and 2012 we need to compare the results generated by the model with above-trend growth during that period. If one assumes trend

\footnotetext{
${ }^{6}$ Anecdotal evidence suggests that payroll lending has also been growing rapidly in other countries, such as in Mexico: http://online.wsj.com/news/articles/SB10001424127887323689604578222130866020660.

${ }^{7}$ Consignado credit accounts for roughly 60 percent of the increase in non-collateralized credit.
} 


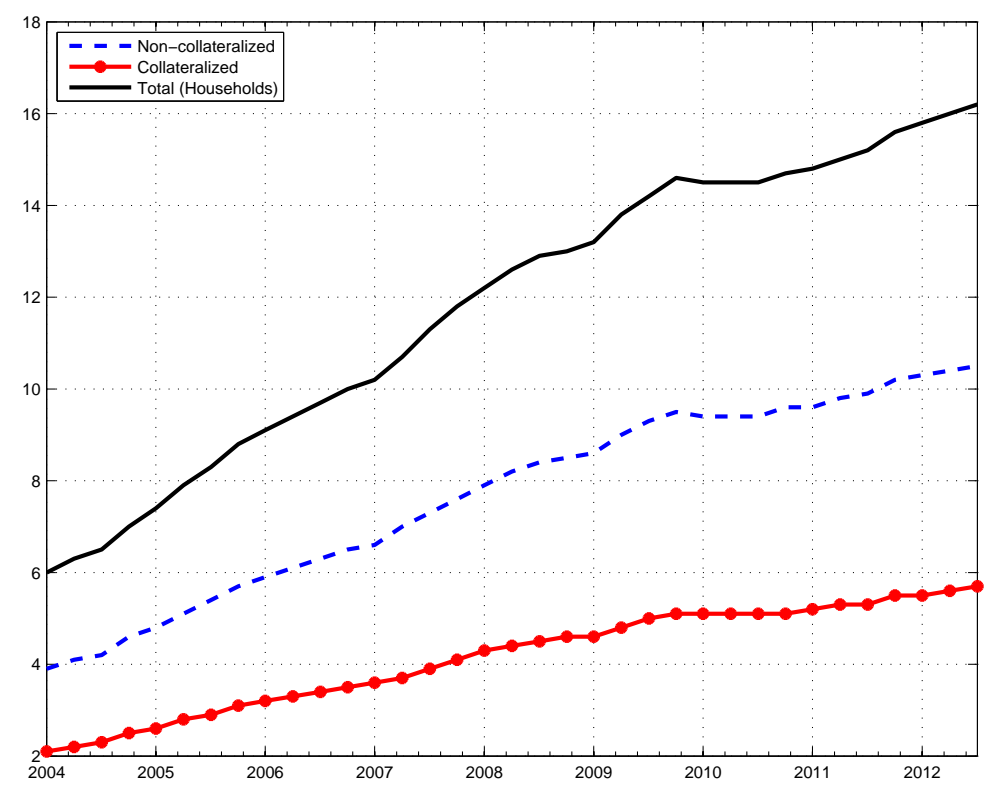

Figure 1.2: Ratio of households nonearmarked credit outstanding to GDP in Brazil, by type. Collateralized credit consists of vehicles financing, other goods financing and mortgages. Non-collateralized credit consists of credit card, personal credit, overdraft and other nonearmarked credit instruments that were not classified in previous types of credit. Source: Brazilian Central Bank, available at www.bcb.gov.br.

growth of 2.5 percent per year, the effects of credit deepening quantified by the model account for 13.4, 4.8, and 9.7 percent of above-trend growth in GDP, consumption, and investment, respectively. These results reflect the fact that the Brazilian economic performance during the 2000s was relatively weak compared with other developing countries. Hence, the modest (in absolute terms) macroeconomic effects of the credit deepening process might have played a relatively important role in the Brazilian context.

Finally, we use our calibrated model to study whether credit deepening changes the way in which monetary policy or technology shocks affect the economy. We find that the impulse response functions to both technology and monetary policy shocks are almost identical in economies with low and high credit-to-GDP ratio. That is, the financial frictions we introduce in the standard new Keynesian DSGE model do not change the propagation mechanisms of these key shocks in any meaningful way. Hence, business cycle moments would barely change across low- and high-credit economies.

This paper is organized as follows. Section 1.2 presents a brief review of the literature. Section 1.3 outlines the theoretical framework. Section 1.4 describes the quantitative analysis, encompassing the calibration procedure, results and sensitivity analysis. Finally, Section 1.5 concludes. 


\section{2 \\ Brief review of the literature}

This paper fits a fast growing literature that integrates financial frictions into the new-Keynesian workhorse model. Bernake and Gertler (1989) and Bernanke et al. (1999) are the leading early references in that literature. See Gertler and Kiyotaki (2010) for a recent survey.

We consider three types of financial frictions. First, we follow Kiyotaki and Moore (1997), who tied the amount an agent can borrow to the value of his collateral asset in a general equilibrium model, and Iacoviello (2005), who introduces this financial friction into a new-Keynesian framework. We also follow these authors by introducing entrepreneurs who can use capital as collateral to borrow. These entrepreneurs can borrow to smooth consumption and remunerate factors of production. By relaxing this financial friction over time, we can emulate the credit expansion we observe for firms.

Second, as in Iacoviello and Neri (2010) and Gerali et al. (2010), we also distinguish patient from impatient households. We tie the capacity to borrow of an impatient household to some collateral as well. This financial friction allows us emulate the consumer credit expansion we observe in practice. However, instead of using only durable goods (such as housing) as collateral, we also consider future labor income, which is arguably in line with the Brazilian experience, where housing-related credit is a small fraction of household credit.

Finally, intermediaries are in line with Curdia and Woodford (2010). In particular, we assume that it is costly for banks to raise funds, which generates an endogenous spread between borrowing and lending rates. This friction is added for the sake of realism.

We study the credit deepening process in Brazil by changing the ability of firms and households to borrow, as in Justiniano et al. (2014), who study the macroeconomic consequences of leveraging and deleveraging in the United States. Notice that we combine different ingredients from the literature in a unique way to study the macroeconomic consequences of credit deepening, and its interaction with monetary policy.

Recent papers use new-Keynesian DSGE models with financial frictions to address questions related to Brazil - e.g., De Castro et al. (2011), Da Silva et al. (2012) and Kanczuk (2013). But we are not aware of other studies of the credit deepening process in Brazil or other Latin American countries using such a model. To the best of our knowledge, our modeling of consignado credit in a DSGE model is also novel - having been developed in parallel with, and independently of, Carvalho et al. (2013) (see footnote 5). 


\section{3 \\ The analytical framework}

Time is discrete. We consider a closed economy populated by three types of infinitely-lived agents: entrepreneurs $(e)$, patient households $(p)$ and impatient households (i), with masses $\mu^{e}, \mu^{p}$ and $\mu^{i}$, respectively. Both entrepreneurs and impatient households have lower discount factors than patient households (i.e., $\beta^{e}, \beta^{i}<\beta^{p}$ ). Consequently, in equilibrium, both entrepreneurs and impatient households have incentives to borrow from patient households. We assume that agents face credit constraints that tie borrowing to some collateral. The tightness of these borrowing constraints governs the amount of credit in the economy. In order to study the interactions between credit and monetary policy, which follows a simple Taylor-rule, we assume price stickiness in retailers that operate under monopolistic competition. Finally, to focus on the effects of a prolonged credit deepening process during the transition to a high-credit economy, we abstract from aggregate uncertainty (and thus omit expectations operators to lighten notation). In Section 1.4.4 we turn to a stochastic version of the model to study the way in which the level of credit in the economy might affect the amplification and propagation of monetary and productivity shocks.

\subsection{1}

\section{Households}

Representative patient and impatient households derive utility from leisure, a nondurable consumption good $C_{t}^{j}$, and a durable consumption good $S_{t}^{j}$, where $j \in\{i, p\}$ indexes the type of the household. We assume preferences for each household are given by:

$\sum_{t=0}^{\infty}\left(\beta^{j}\right)^{t}\left\{\log \left(\left[\xi\left(C_{t}^{j}\right)^{\sigma}+(1-\xi)\left(S_{t}^{j}\right)^{\sigma}\right]^{\frac{1}{\sigma}}\right)-\frac{\left(L_{t}^{j}\right)^{1+\varphi}}{1+\varphi}\right\}$, where $\beta^{j} \in(0,1)$ and $\varphi>0$,

where $L_{t}^{j}, j \in\{i, p\}$ denotes labor supply. Nondurable and durable consumption are combined with a CES aggregator.

\section{Patient households}

Given that $\beta^{p}>\max \left\{\beta^{i}, \beta^{e}\right\}$, patient households are more prone to save. We focus on transitions between a low-credit and a high-credit steady state along which patient households are always lenders. Thus, we do not need to explicitly account for a borrowing constraint in their problems. In particular, given the real wage rate $\left(W_{t}^{p}\right)$, the relative price of the durable good in terms of the final good $\left(q_{t}^{S}\right)$, and the interest rate accrued on deposits $\left(r_{t}^{h}\right)$, they 
choose a stream of nondurable consumption $\left(C_{t}^{p}\right)$, durable consumption $\left(S_{t}^{p}\right)$, labor services $\left(L_{t}^{p}\right)$, and bank deposits $\left(D_{t}^{p}\right)$ in order to maximize (1-1) subject to the budget constraint

$$
C_{t}^{p}+q_{t}^{S} S_{t}^{p}+D_{t}^{p} \leq W_{t}^{p} L_{t}^{p}+q_{t}^{S}\left(1-\delta_{S}\right) S_{t-1}^{p}+\frac{\left(1+r_{t-1}^{h}\right)}{\pi_{t}} D_{t-1}^{p}+T_{t}
$$

where $\pi_{t}=P_{t} / P_{t-1}$ is the gross inflation rate, and $\delta_{S}$ is the rate of depreciation of the durable good. We assume that patient agents own all banks and firms in the economy and, thus, receive their profits, which are aggregated in $T_{t}$.

\section{Impatient households}

In contrast with patient households, the impatient ones are borrowers. Hence, we need to account for a borrowing constraint in their problems. In particular, given $W_{t}^{i}, q_{t}^{S}$ and $r_{t}^{h}$, they choose a stream of nondurable consumption $C_{t}^{i}$, durable consumption $S_{t}^{i}$, labor services $L_{t}^{i}$ and debt $B_{t}^{i}$ in order to maximize (1-1) subject to the budget constraint

$$
C_{t}^{i}+q_{t}^{S} S_{t}^{i}+\frac{1+r_{t-1}^{h}}{\pi_{t}} B_{t-1}^{i} \leq W_{t}^{i} L_{t}^{i}+q_{t}^{S}\left(1-\delta_{S}\right) S_{t-1}^{i}+B_{t}^{i}
$$

and the following borrowing constraint:

$$
\left(1+r_{t}^{h}\right) B_{t}^{i} \leq \tau_{t}^{W L} \pi_{t+1} W_{t+1}^{i} L_{t+1}^{i}+\tau_{t}^{S} q_{t+1}^{S} \pi_{t+1}\left(1-\delta_{S}\right) S_{t}^{i}
$$

This borrowing constraint states that impatient households can borrow up to a fraction $\tau_{t}^{W L}$ of the value of next period's labor income plus a fraction $\tau_{t}^{S}$ of the value of next period's stock of durable goods. We assume that the deposit rate and the rates that apply to household credit are the same. This simplification is motivated by the fact that consignado and consumer collateralized credits carry a relatively low interest rate in Brazil. We thus set this spread to zero and allow for a positive spread only when credit is extended to entrepreneurs.

Similar constraints, which tie debt to the value of some collateral, have been adopted in the literature (e.g. Kiyotaki and Moore, 1997; Iacoviello, 2005; Gerali et al., 2010). However, to our knowledge, our modeling of a credit constraint that depends on future labor income is novel. ${ }^{8}$

By calibrating $\tau_{t}^{W L}$ to replicate the expansion of non-collateralized credit (which includes consignado), we can study the macroeconomic effects of such expansion. Similarly, we will calibrate $\tau_{t}^{S}$ to study the expansion of collateralized credit.

${ }^{8}$ See, however, footnote 5 . 


\subsection{2}

\section{Entrepreneurs}

Entrepreneurs have preferences given by

$$
\sum_{t=0}^{\infty}\left(\beta^{e}\right)^{t} \log \left(C_{t}^{e}\right), \text { where } \beta^{e} \in(0,1),
$$

where, again, $\beta^{e}<\beta^{p}$. Moreover, they have access to a production technology, in which labor inputs $\left(L_{t}^{p}, L_{t}^{i}\right)$ and capital $K_{t}$ are employed to produce a wholesale good $Y_{t}^{e}$, according to

$$
Y_{t}^{e}=A_{t} K_{t-1}^{\alpha}\left[\left(\mu^{p} L_{t}^{p}\right)^{\theta}\left(\mu^{i} L_{t}^{i}\right)^{1-\theta}\right]^{1-\alpha}
$$

where $A_{t}$ is the level of technology, ${ }^{9}$ common to all entrepreneurs, and $\alpha \in(0,1)$ is the capital share. Notice that, as in Iacoviello and Neri (2010), we assume complementarity across labor types, which is governed by the parameter $\theta \in(0,1)$.

In the economies that we analyze, entrepreneurs act as borrowers. Hence, we need to account for a borrowing constraint in their problems. Unlike households, entrepreneurs use capital as collateral.

Given prices, entrepreneurs choose a stream of nondurable consumption $C_{t}^{e}$, capital $K_{t}$, debt $B_{t}^{e}$, and labor inputs $\left(L_{t}^{p}, L_{t}^{i}\right)$ to maximize (1-2) subject to (1-3), the budget contraint

$C_{t}^{e}+W_{t}^{p} L_{t}^{p}+W_{t}^{i} L_{t}^{i}+\frac{\left(1+r_{t-1}^{e}\right) B_{t-1}^{e}}{\pi_{t}}+q_{t}^{K} K_{t} \leq q_{t}^{W} Y_{t}^{e}+B_{t}^{e}+q_{t}^{K}\left(1-\delta_{K}\right) K_{t-1}$,

and the borrowing constraint

$$
\left(1+r_{t}^{e}\right) B_{t}^{e} \leq \tau_{t}^{K} q_{t+1}^{K} \pi_{t+1}\left(1-\delta_{K}\right) K_{t}
$$

where $\delta_{K}$ is the depreciation rate of capital, $q_{t}^{K}$ is the price of capital in terms of the final good, and $q_{t}^{W} \equiv P_{t}^{W} / P_{t}$ is the relative price of the wholesale good $Y_{t}^{e}$. Notice that $r_{t}^{e}$ is the nominal interest rate faced by entrepreneurs. Later, we explain how the credit spread, $\omega_{t}=\left(1+r_{t}^{e}\right) /\left(1+r_{t}^{h}\right)-1$, is determined endogenously. Finally, by imposing an exogenous path to $\tau_{t}^{K}$, aiming to replicate the expansion of corporate credit in Brazil, we can study the macroeconomic effects of such expansion.

\footnotetext{
${ }^{9}$ In our analysis of the transition effects of credit deepening we abstract from technology
} shocks. We then analyze their aggregate effects around low- and high-credit steady states. 


\subsection{3}

\section{Firms}

There are four types of firms: competitive capital producers, competitive producers of durable goods, retailers who operate in a monopolistic competitive market, and competitive final goods producers. All firms are owned by patient households.

\section{Capital producers}

At the beginning of each period, capital producers buy an amount of the final good $I_{t}^{K}$ from final goods producers and the stock of depreciated capital $\left(1-\delta_{K}\right) K_{t-1}$ at price $q_{t}^{K}$ from entrepreneurs. The stock of depreciated capital is transformed one-to-one into new capital, while the transformation of final goods into new capital is subject to a quadratic adjustment cost. The new capital $K_{t}$ is sold to entrepreneurs at relative price $q_{t}^{K}$ to be used in production in the subsequent period.

Hence, new capital is chosen to maximize

$$
\sum_{t=0}^{\infty} \Delta_{t}\left[q_{t}^{K}\left(K_{t}-\left(1-\delta_{K}\right) K_{t-1}\right)-I_{t}^{K}\right]
$$

subject to the law of motion

$$
K_{t}=\left(1-\delta_{K}\right) K_{t-1}+\left[1-\frac{\kappa_{K}}{2}\left(\frac{I_{t}^{K}}{I_{t-1}^{K}}-1\right)^{2}\right] I_{t}^{K}
$$

where the parameter $\kappa_{K}$ determines how costly it is to adjust capital, and $\Delta_{t}$ is the stochastic discount factor of patient households.

\section{Producers of durable goods}

At the beginning of each period, producers of durable goods buy an amount of the final good $I_{t}^{S}$ from final goods firms and the stock of depreciated durable goods $\left(1-\delta_{S}\right) S_{t-1}$ at relative price $q_{t}^{S}$ from both patient and impatient households. The stock of depreciated durable goods is transformed one-toone into new durable goods, while the transformation of final goods into new durable goods is subject to a quadratic adjustment cost. New durable goods $S_{t}$ are sold at relative price $q_{t}^{S}$ to both patient and impatient households.

Hence, durable goods producers choose the level of production to maximize

$$
\sum_{t=0}^{\infty} \Delta_{t}\left[q_{t}^{S}\left(S_{t}-\left(1-\delta_{S}\right) S_{t-1}\right)-I_{t}^{S}\right]
$$


subject to the law of motion

$$
S_{t}=\left(1-\delta_{S}\right) S_{t-1}+\left[1-\frac{\kappa_{S}}{2}\left(\frac{I_{t}^{S}}{I_{t-1}^{S}}-1\right)^{2}\right] I_{t}^{S}
$$

where the parameter $\kappa_{S}$ determines how costly it is to adjust durable goods. Any profits originated in this sector are transferred to patient households.

\section{Retail firms and final goods producers}

We assume monopolistic competition among retail firms. Each retail firm $m$ buys the wholesale good $Y_{t}^{e}$ from entrepreneurs at the price $P_{t}^{W}$ and differentiates it at no cost. They set prices $P_{t}(m)$ in order to maximize profits subject to the demand originating from final goods producers and also subject to quadratic price adjustment costs that arise whenever a firm changes its price by more than a weighted average of past and steady-state inflation (with relative weights equal to $\iota$ and $(1-\iota)$, respectively).

Let $Y_{t}(m)$ denote production of variety $m$. We assume that final good producers are competitive, and they simply aggregate, through a CES composite, the continuum of differentiated varieties produced by retailers. In particular,

$$
Y_{t}=\left[\int_{0}^{1} Y_{t}(m)^{\frac{\varepsilon-1}{\varepsilon}} d m\right]^{\frac{\varepsilon}{\varepsilon-1}}
$$

where $\varepsilon$ is the elasticity of substitution between varieties. Let $P_{t}$ be the associated Dixit-Stiglitz price index.

This final good is purchased by patient households, impatient households and entrepreneurs for consumption, and by capital and durable goods producers for production.

Finally, it remains to formalize retail firm $m$ 's problem. $P_{t}(m)$ is chosen to maximize

$$
\sum_{t=0}^{\infty} \Delta_{t}\left[P_{t}(m) Y_{t}(m)-P_{t}^{W} Y_{t}(m)-\frac{\kappa_{P}}{2}\left(\frac{P_{t}(m)}{P_{t}(m-1)}-\pi_{t-1}^{\iota} \bar{\pi}^{1-\iota}\right)^{2} P_{t} Y_{t}\right],
$$

subject to the following demand schedule obtained from the cost-minimization problem of fina goods producers:

$$
Y_{t}(m)=\left(\frac{P_{t}(m)}{P_{t}}\right)^{-\varepsilon} Y_{t}
$$

The parameter $\kappa_{P}$ controls the price adjustment cost and dictates the degree of price stickiness in the economy and $\bar{\pi}$ denotes steady-state inflation. Any 
profits originated in this sector are transferred to patient households.

\subsection{4 \\ Banks}

Banks behave competitively, taking both $r_{t}^{h}$ and $r_{t}^{e}$ as given. Recall that $r_{t}^{h}$ is the interest rate on both the debt of impatient households and the savings of patient ones. At the beginning of each period, banks collect deposits from patient households $D_{t}$, which are lent to both impatient households and entrepreneurs. Originating loans to entrepreneurs entails an extra cost which is borne out in terms of the final good. As in Curdia and Woodford (2010), we assume such cost is given by $\eta\left(B_{t}^{e}\right)^{\gamma}$, with $\eta>0$ and $\gamma>1$. Intuitively, this is a shortcut to capture both agency and operational costs that are not modeled explicitly. As explained earlier, we assume that such costs are not present when banks lend to impatient households.

The excess funds of the banks are given by

$$
D_{t}-B_{t}^{e}-B_{t}^{i}-\eta\left(B_{t}^{e}\right)^{\gamma},
$$

which are transferred to patient households. Let the credit spread $\omega_{t}$ be defined implicitly by $\left(1+r_{t}^{e}\right)=\left(1+\omega_{t}\right)\left(1+r_{t}^{h}\right)$. Given that assets must equal liabilities at the end of the period, the following equation must hold

$$
D_{t}=\left(1+\omega_{t}\right) B_{t}^{e}+B_{t}^{i}
$$

By plugging (1-5) into (1-4), we obtain

$$
\omega_{t} B_{t}^{e}-\eta\left(B_{t}^{e}\right)^{\gamma}
$$

which is maximized at $B_{t}^{e}=\left(\eta \gamma / \omega_{t}\right)^{1 /(1-\gamma)}$. Since $\gamma>1$, the model induces a positive correlation between the credit spread $\omega_{t}$ and the amount borrowed by entrepreneurs $B_{t}^{e}$.

\subsection{5}

\section{Monetary policy}

Monetary policy is conducted through a Taylor-rule with interest rate smoothing. In particular,

$$
\left(1+r_{t}^{h}\right)=(1+r)^{1-\rho}\left(1+r_{t-1}^{h}\right)^{\rho}\left(\frac{\pi_{t}}{\pi}\right)^{\phi_{\pi}(1-\rho)}\left(\frac{y_{t}}{y_{t-1}}\right)^{\phi_{y}(1-\rho)} e^{u_{t}^{r}},
$$

where $\phi_{\pi}$ and $\phi_{y}$ are the weights assigned to inflation and output stabilization, respectively, $\pi$ and $r$ are the steady-state levels of inflation and the policy rate, 
respectively, and $u_{t}^{r}$ is a monetary policy shock. ${ }^{10}$

\subsection{6}

\section{Market clearing}

The definition of the equilibrium is standard. We assume that capital, wholesale good, durable good, and both types of labor markets are competitive. In particular, notice that the market clearing condition for the wholesale good reads:

$$
\int_{0}^{1} Y_{t}(m) d m=\mu^{e} Y_{t}^{e}
$$

In contrast, we assume monopolistic competition at the retail level, where the nondurable good is composed. Finally, given that $C_{t}=\mu^{p} C_{t}^{p}+\mu^{i} C_{t}^{i}+\mu^{e} C_{t}^{e}$, the market clearing condition in the nondurable good market is

$$
Y_{t}=C_{t}+I_{t}^{S}+I_{t}^{K}+\eta\left(B_{t}^{e}\right)^{\gamma}+\text { all adjustment costs. }
$$

\section{4}

\section{Quantitative analysis}

After calibrating the model outlined above, we use it to perform two exercises. First, in order to assess the macroeconomic effects of the credit expansion observed in Brazil, we solve for the time-varying paths of $\tau_{t}^{W L}, \tau_{t}^{S}$, and $\tau_{t}^{K}$ that generate paths for non-collateralized credit, collateralized credit to households, and credit to non-financial corporations that resemble their counterparts in the data (see Figures 1.1 and 1.2).

Second, in a stochastic version of the model, we evaluate the propagation mechanism of both technology and monetary policy shocks (which we add to the model for this exercise only). In particular, we compare impulse response functions to these shocks in economies with low and high levels of credit.

\section{4 .1}

\section{Calibration}

We consider several sources of information to calibrate the parameters of the model, in which the time period is set to one quarter. Whenever we set a parameter to match a given statistic for the Brazilian economy, we consider its average between 2004 and 2012 .

Steady state inflation is set to $5.5 \%$ per year. Regarding the discount factors, we set $\beta^{p}=0.9834$ to generate an annual nominal interest rate that

${ }^{10} \mathrm{In}$ our analysis of the transition effects of credit deepening we abstract from monetary policy shocks. We then analyze their aggregate effects around low- and high-credit steady states. 
accrues on SELIC rate of 12.5 percent in steady-state. We set $\beta^{i}=\beta^{e}=0.91$, which is associated with an annual "subjetive time-discount rate" of 52 percent. We pick this extreme value for two reasons. First, as we show below, low values for $\beta^{p}$ and $\beta^{e}$ favor the hypothesis that the credit deepening process boosts economic growth during the credit deepening process. Second, with high values for $\beta^{p}$ and $\beta^{e}$, the borrowing constraints for impatient households and entrepreneurs may not be binding at times during the transition. ${ }^{11}$

The Frisch elasticity $1 / \varphi$ is set to one, which is within the range commonly used in the literature. We follow Fernandez-Villaverde and Krueger (2004) to calibrate the parameters associated with preferences for durable and nondurable goods. In the absence of definitive estimates for $\sigma$, we set it to zero, so that the composite becomes a Cobb-Douglas, $\left(C_{t}^{j}\right)^{\xi}\left(S_{t}^{j}\right)^{1-\xi}, j=i, p$, with $\xi$ set to 0.8 .

The depreciation rate of capital $\delta_{K}$ is set to 0.025 such that the investment to GDP ratio is approximately 18 percent. The adjustment cost parameter $\kappa_{K}$ is 2.53, which is in line with the value estimated in De Castro et al. (2011). In the absence of similar information regarding the production of durable goods, we set $\delta_{S}=\delta_{K}$ and $\kappa_{S}=\kappa_{K}$.

Regarding the Cobb-Douglas technology used by entrepreneurs, since information on patient and impatient labor income shares in Brazil is not available, we set $\theta=0.7$ to generate a ratio of average household debt to annual income of 22 percent. The capital share $\alpha$ is set to 0.44 , in line with the evidence for Brazil reported in Paes and Bugarin (2006).

In line with previous literature, the elasticity of substitution $\varepsilon$ between goods is set to 6 , which corresponds to a markup of 20 percent. The parameter $\kappa_{P}$, which measures the degree of price stickiness in the retail sector, is calibrated to 50. As usual, this parameter can be mapped into a degree of price stickiness of 0.75 in the Calvo (1983) model, once the quadratic adjustment cost model and the Calvo model are cast as log-linear approximations around a zero inflation steady state. Finally, $\iota$, which governs indexation, is set to 0.158 , as in Gerali et al. (2010).

We follow De Castro et al. (2011) to calibrate the parameters associated with the Taylor Rule. In particular, $\phi_{y}=0.16, \phi_{\pi}=2.43$ and $\rho=0.79$.

Regarding the banking sector, we set $\eta=0.0309$ and $\gamma=2$ to generate a spread of 4.08 percent per year. The spread is calculated using the Brazilian prime rate, which averages interest rates on loans made to firms that are considered preferential borrowers. Loans to these firms embed lower default

${ }^{11}$ For a recent article that deals with credit constraints that bind occasionally, see Guerrieri and Iacoviello (2013). 
risk than loans to other firms. Hence, the targeted value of 4.08 underestimates the average spread in the Brazilian economy. As we show below, this calibration of $\eta$ and $\gamma$ also favors the hypothesis that the credit deepening process boosts economic growth during the credit deepening process.

We postpone the discussion of how we calibrate the sequence $\left\{\tau_{t}^{W L}, \tau_{t}^{S}, \tau_{t}^{K}\right\}$ to the next section. Finally, we set masses $\mu^{p}, \mu^{i}$ and $\mu^{e}$ equal to one. Table 1.1 summarizes the calibration procedure.

Table 1.1: Calibration. See Section 1.4.1 for details.

\begin{tabular}{c|c|c}
\hline \hline Parameter & Description & Value \\
\hline \hline$\beta^{p}$ & Discount Factor - Patients & 0.9834 \\
\hline$\beta^{i}, \beta^{e}$ & Discount Factor - Impatients and Entrepreneurs & 0.91 \\
\hline$\mu^{p}, \mu^{i}, \mu^{e}$ & Mass - Patients, Impatients and Entrepreneurs & 1 \\
\hline$\varphi$ & Inverse of the Frisch Elasticity & 1 \\
\hline$\sigma$ & Elasticity Between Nondurable and Durable Goods & 0 \\
\hline$\xi$ & Weight of the Nondurable Good on the Utility Function & 0.8 \\
\hline$\delta_{K}, \delta_{S}$ & Depreciation - Capital and Durable Goods & 0.025 \\
\hline$\kappa_{K}, \kappa_{S}$ & Adjustment Cost - Capital and Durable Goods & 2.53 \\
\hline$\alpha$ & Capital Share in the Production Function & 0.44 \\
\hline$\theta$ & Share of Patient Households in the Production Function & 0.7 \\
\hline$\kappa_{P}$ & Price Adjustment Cost - Final Good & 50 \\
\hline$\iota$ & Steady State Inflation Weight - Indexation & 0.158 \\
\hline$\varepsilon$ & Elasticity of Substitution - Final Good & 6 \\
\hline$\rho$ & Smoothing Parameter of the Taylor Rule & 0.79 \\
\hline$\phi_{y}$ & Output Weight of Taylor Rule & 0.16 \\
\hline$\phi_{\pi}$ & Inflation Weight of Taylor Rule & 2.43 \\
\hline$\eta$ & Spread & 0.0309 \\
\hline$\gamma$ & Spread & 2 \\
\hline \hline
\end{tabular}

\section{4 .2}

\section{Macroeconomic effects of credit deepening}

In order to assess the macroeconomic effects of the credit expansion we observe in Brazil, we solve for the time-varying paths of $\tau_{t}^{W L}, \tau_{t}^{S}$, and $\tau_{t}^{K}$ that generate paths for non-collateralized credit, collateralized credit to households, and credit to non-financial corporations that resemble their counterparts in the data. We smooth the trajectories for $\tau_{t}^{W L}, \tau_{t}^{S}$, and $\tau_{t}^{K}$ using a third degree polynomial. As in Justiano et al. (2014), we assume that the evolution of $\tau_{t}^{W L}$, $\tau_{t}^{S}$,and $\tau_{t}^{K}$ is perfect foreseen after the initial unforeseen shock in 2004, when the credit deepening process arguably started. After 2012, we keep $\tau_{t}^{W L}, \tau_{t}^{S}$, and $\tau_{t}^{K}$ constant. $^{12}$

\footnotetext{
${ }^{12}$ To implement this exercise, we apply the shooting algorithm in Dynare to solve the system of equations given by the first-order conditions of the agents' optimization problems
} 
Figure 1.3 shows the evolution of $\tau_{t}^{W L}, \tau_{t}^{S}$, and $\tau_{t}^{K}$, whereas Figure 1.4 compares the credit deepening experiment in the model with the data. Notice that the model is able to replicate the evolution of the credit series fairly well, except for the last years of the data on credit to non-financial corporations ("entrepreneurs"). ${ }^{13}$
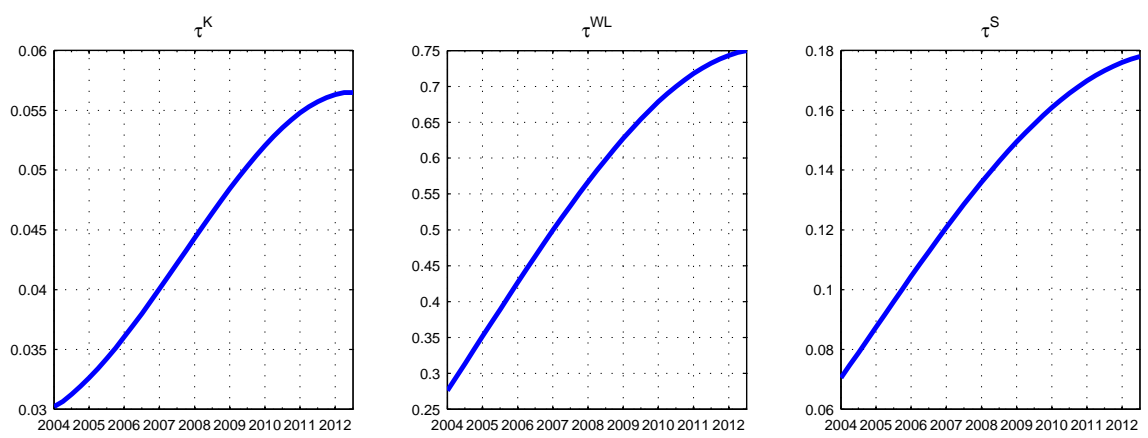

Figure 1.3: Credit deepening experiment: evolution of $\tau_{t}^{K}, \tau_{t}^{W L}$ and $\tau_{t}^{S}$.
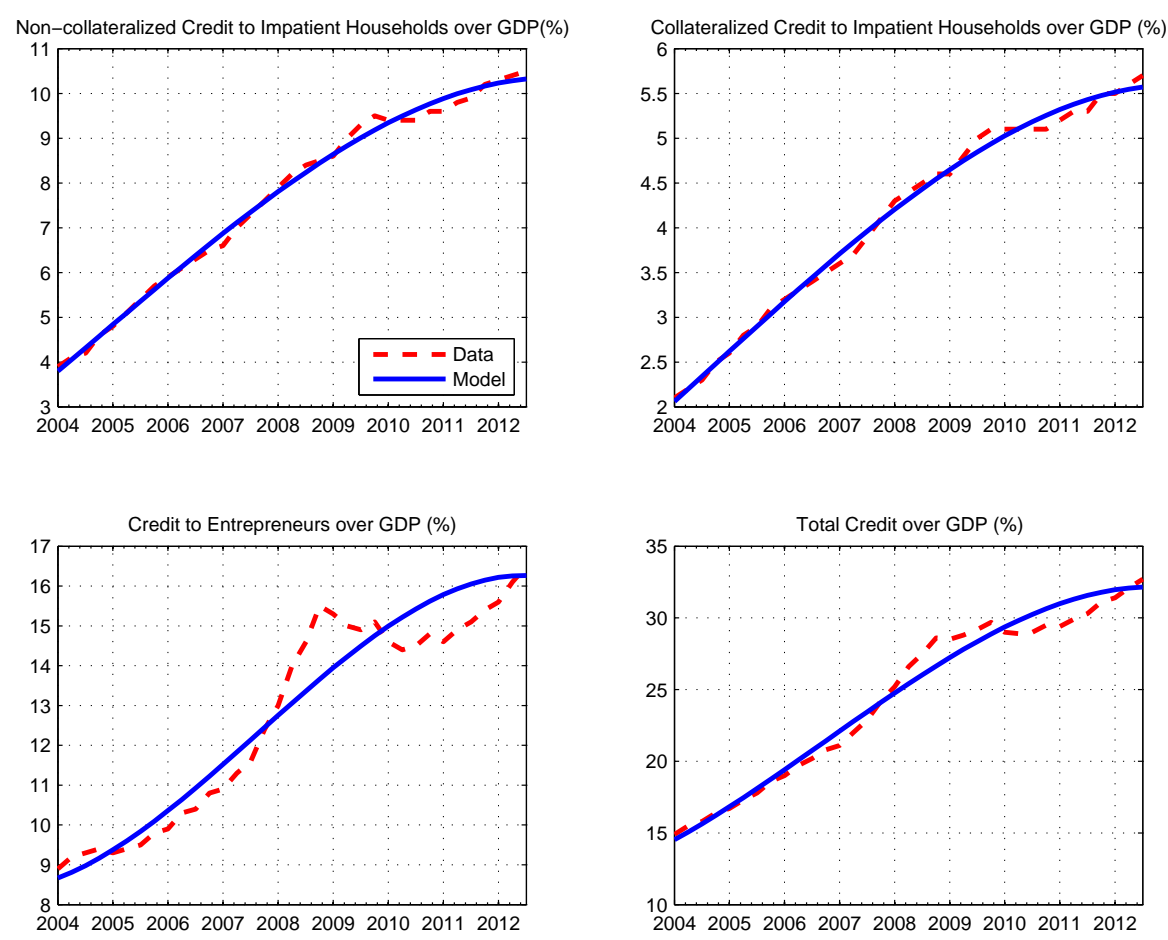

Figure 1.4: Credit deepening experiment: credit variables (model and data). See notes in Figure 1.1 and 1.2 on how these credit variables are constructed.

and the market clearing conditions. The first-order and market clearing conditions are described in a separate document available upon request.

${ }^{13}$ To be precise, in that case the fitted third degree polynomial would decrease towards the end of the sample period, so we tweak it to be strictly monotone. In the next section, as a robustness check, we report results for paths of $\tau_{t}^{W L}, \tau_{t}^{S}$, and $\tau_{t}^{K}$ chosen to fit pointwise the trajectories of the credit variables. 
Figure 1.5 reports the trajectories of GDP, consumption, investment, and inflation in the model economy. The macroeconomic effects of credit deepening are small. GDP increases by nearly 2 percent, consumption by 1 percent, and investment by 3 percent.
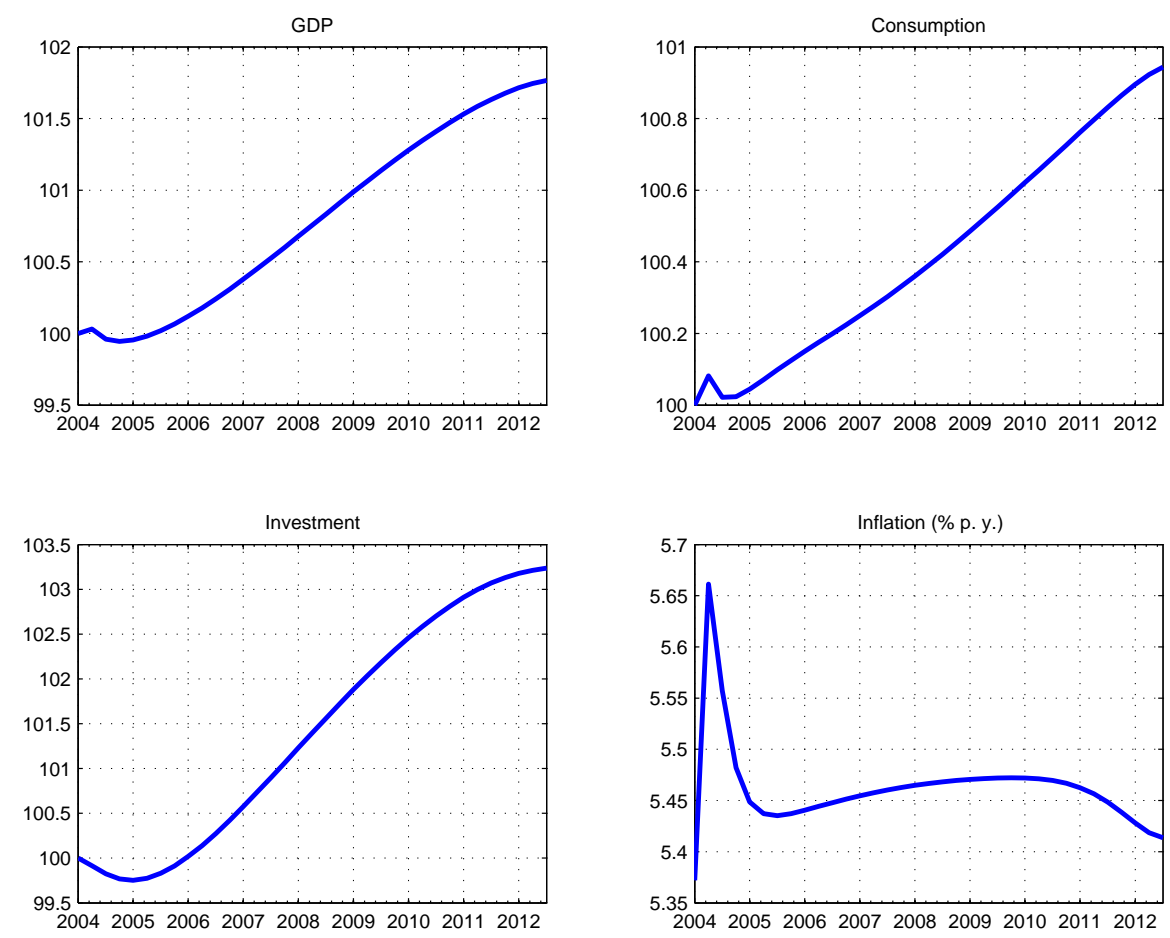

Figure 1.5: Credit deepening experiment: macro variables (model).

Consumption in the model aggregates nondurable consumption across types of agents, whereas investment aggregates investment in both durable goods by households and capital by entrepreneurs. Figure 1.6 reports the evolution of these variables, as well as the evolution of the stock of durable goods and capital by types of agents.

Once the credit deepening process started, both credit constraints faced by the impatient households and entrepreneurs ease, which make them consume and invest more. In order to clear markets, the price of the nondurable good must increase (as the spike in the inflation rate in Figure 5 illustrates) and, thus, patient households reduce their consumption of nondurable goods and investment in durable goods.

As the credit deepening process evolves, consumption and investment of patient households increase. After the initial spike of 40 percent, investment of impatient households declines, whereas consumption displays an inverse Ushape pattern. Notice that the impatient households' stock of durable goods increases monotonically, while that of patient households follows a U-shape pattern. Intuitively, durable goods have a dual role in the model. First, 

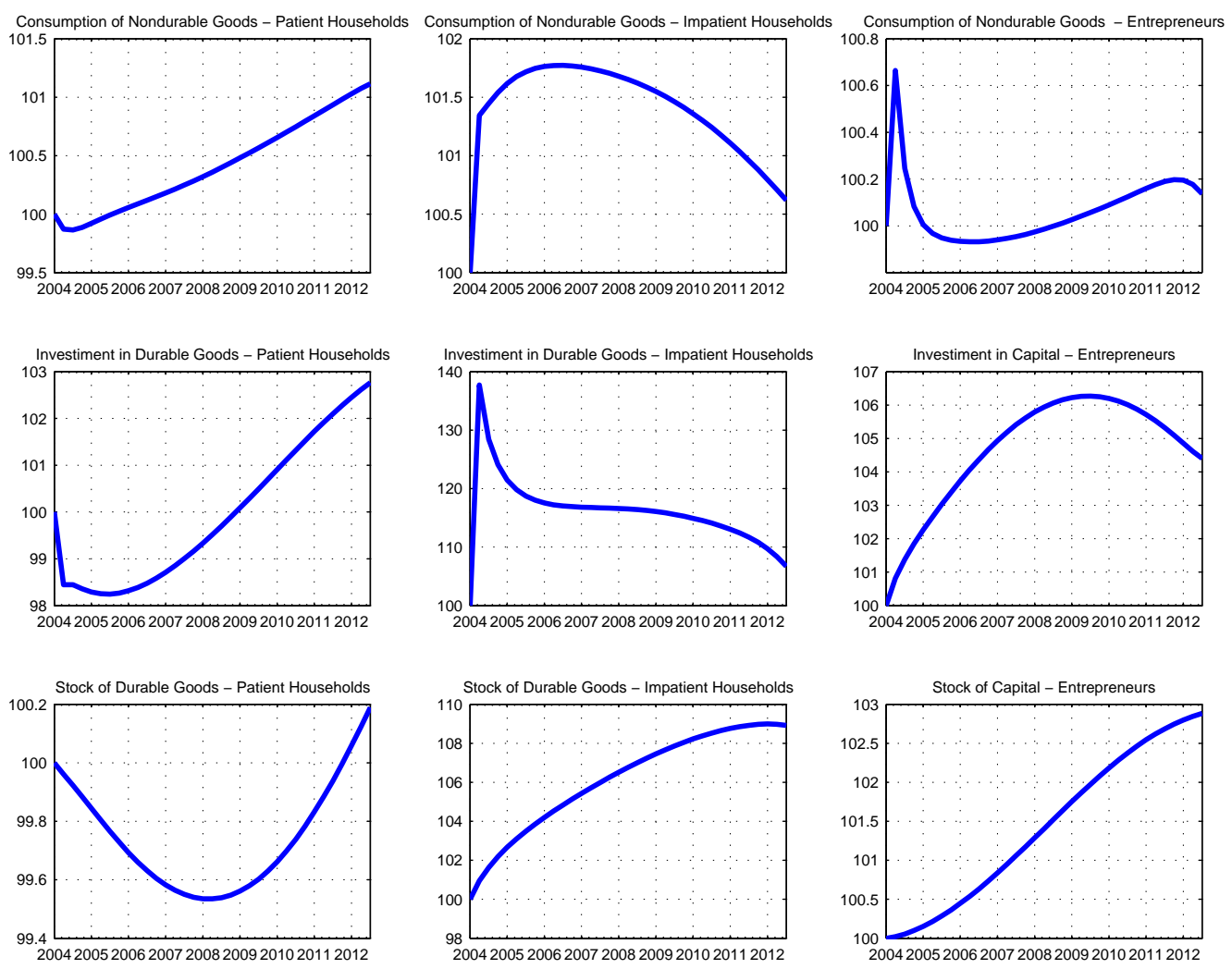

Figure 1.6: Credit deepening experiment: consumption, investment and stocks.

they generate utility for both types of households. Second, they relax credit constraints of impatient households. Hence, impatient households have more incentives to accumulate durable goods than patient households. In the first years of the credit deepening process, market clearing prices imply that patient households exchange durable for nondurable goods, whereas in the later years, impatient households do the opposite.

Similarly, as the credit deepening process evolves, investment in capital follows an inverse U-shape path, allowing entrepreneurs to increase their stock of capital by 3 percent. Overall, the effects on entrepreneurs' consumption of nondurable goods are very small.

In terms of magnitude, the strongest effects are on investment in durable goods by impatient households and investment in capital, which increase by 9 and 4.5 percent, respectively. In contrast, consumption by each type of agent increased by at most one percent.

In absolute terms, the effects of the credit deepening process are modest. However, the model lacks trend growth. Depending on the actual level of trend growth in Brazil, the effects of credit deepening as quantified by our model might explain a sizeable share of above-trend growth in actual GDP, consumption and investment. 
Table 1.2 describes five scenarios for trend growth, ranging from 1.5 to 3.5 percent per year. For each scenario, we divide the percentage increase in GDP, consumption, and investment produced by the model for the 2004-2012 period by the cumulative above-trend growth in the actual data on each of those variables. This is the share of the gap between economic growth and its trend that can be attributed to the credit deepening process, according to the calibrated model. In our preferred scenario, which considers a growth trend of 2.5 percent per year, the credit deepening process accounts for 13.4, 4.8, and 9.7 percent of above-trend growth in GDP, consumption, and investment, respectively. ${ }^{14}$ Under more optimistic assumptions about the growth trend, the model can account for up to $52.5 \%$ of the gap for GDP. In contrast, if the growth trend is only 1.5 percent, the credit deepening process accounts for only 7.4 percent above-trend GDP growth.

Table 1.2: Credit deepening experiment: comparison with the data. Growth rates between 2004 and 2012. Data on GDP, consumption and investment in capital are obtained from National Accounts, available at www.ipeadata.gov.br.

\begin{tabular}{|c|c|c|c|c|c|c|c|c|}
\hline & \multicolumn{2}{|c|}{ GDP } & \multicolumn{2}{|c|}{ "Consumption } & \multicolumn{2}{|c|}{ "Consumption + I. in Durables } & \multicolumn{2}{|c|}{ "Investment (capital) } \\
\hline & \multicolumn{2}{|c|}{$\begin{array}{l}\text { Growth (data): } 40.7 \% \\
\text { Growth (model): } 1.7 \%\end{array}$} & \multicolumn{2}{|c|}{$\begin{array}{l}\text { Growth (data): } 48.4 \% \\
\text { Growth (model): } 0.9 \%\end{array}$} & \multicolumn{2}{|c|}{$\begin{array}{l}\text { Growth (data): } 48.4 \% \\
\text { Growth (model): } 1.5 \%\end{array}$} & \multicolumn{2}{|c|}{$\begin{array}{l}\text { Growth (data): } 82.6 \% \\
\text { Growth (model): } 4.5 \%\end{array}$} \\
\hline $\begin{array}{l}\text { Trend growth } \\
\text { (\% p.y.) }\end{array}$ & $\begin{array}{l}\text { Above trend } \\
\text { growth }(\%)\end{array}$ & $\begin{array}{c}\text { Model } \\
\text { share (\%) }\end{array}$ & $\begin{array}{l}\text { Above trend } \\
\text { growth (\%) }\end{array}$ & $\begin{array}{c}\text { Model } \\
\text { share }(\%)\end{array}$ & $\begin{array}{l}\text { Above trend } \\
\text { growth (\%) }\end{array}$ & $\begin{array}{c}\text { Model } \\
\text { share }(\%)\end{array}$ & $\begin{array}{l}\text { Above trend } \\
\text { growth }(\%)\end{array}$ & $\begin{array}{c}\text { Model } \\
\text { share (\%) }\end{array}$ \\
\hline $1.5 \%$ & $23.1 \%$ & $7.4 \%$ & $29.8 \%$ & $3.0 \%$ & $29.8 \%$ & $5.0 \%$ & $59.7 \%$ & $7.5 \%$ \\
\hline $2.0 \%$ & $17.7 \%$ & $9.6 \%$ & $24.2 \%$ & $3.7 \%$ & $24.2 \%$ & $6.2 \%$ & $52.8 \%$ & $8.5 \%$ \\
\hline $2.5 \%$ & $12.7 \%$ & $13.4 \%$ & $18.8 \%$ & $4.8 \%$ & $18.8 \%$ & $8.0 \%$ & $46.2 \%$ & $9.7 \%$ \\
\hline $3.0 \%$ & $7.8 \%$ & $21.7 \%$ & $13.7 \%$ & $6.6 \%$ & $13.7 \%$ & $10.9 \%$ & $39.9 \%$ & $11.3 \%$ \\
\hline $3.5 \%$ & $3.2 \%$ & $52.5 \%$ & $8.9 \%$ & $10.1 \%$ & $8.9 \%$ & $16.9 \%$ & $34.0 \%$ & $13.2 \%$ \\
\hline
\end{tabular}

Altogether, these results highlight the relatively poor performance of the Brazilian economy during the 2000s. The modest (in absolute terms) aggregate effects of the credit deepening process might have played a relatively important role in the Brazilian context.

Figure 1.7 shows the evolution of labor market outcomes. As in Justiano et al. (2014), once credit deepening started, labor services of patient and impatient households move in opposite directions. However, as the process evolves, labor services supplied by impatient households increase by 2 percent, whereas those supplied by patient households barely increase. Moreover, notice that for impatient households, wage and labor services are negatively associated, whereas for patient households they are positively associated. Hence, for patient households, demand for labor services seems to be driving force behind these movements. In contrast, as the credit deepening process

\footnotetext{
${ }^{14}$ In the National Accounts, the measure of consumption includes the service flow of some durable goods, such as housing. Hence, in the model we also consider an alternative measure of consumption that includes investment in durable goods. In this case, the credit deepening process accounts for 8 percent of above-trend growth.
} 

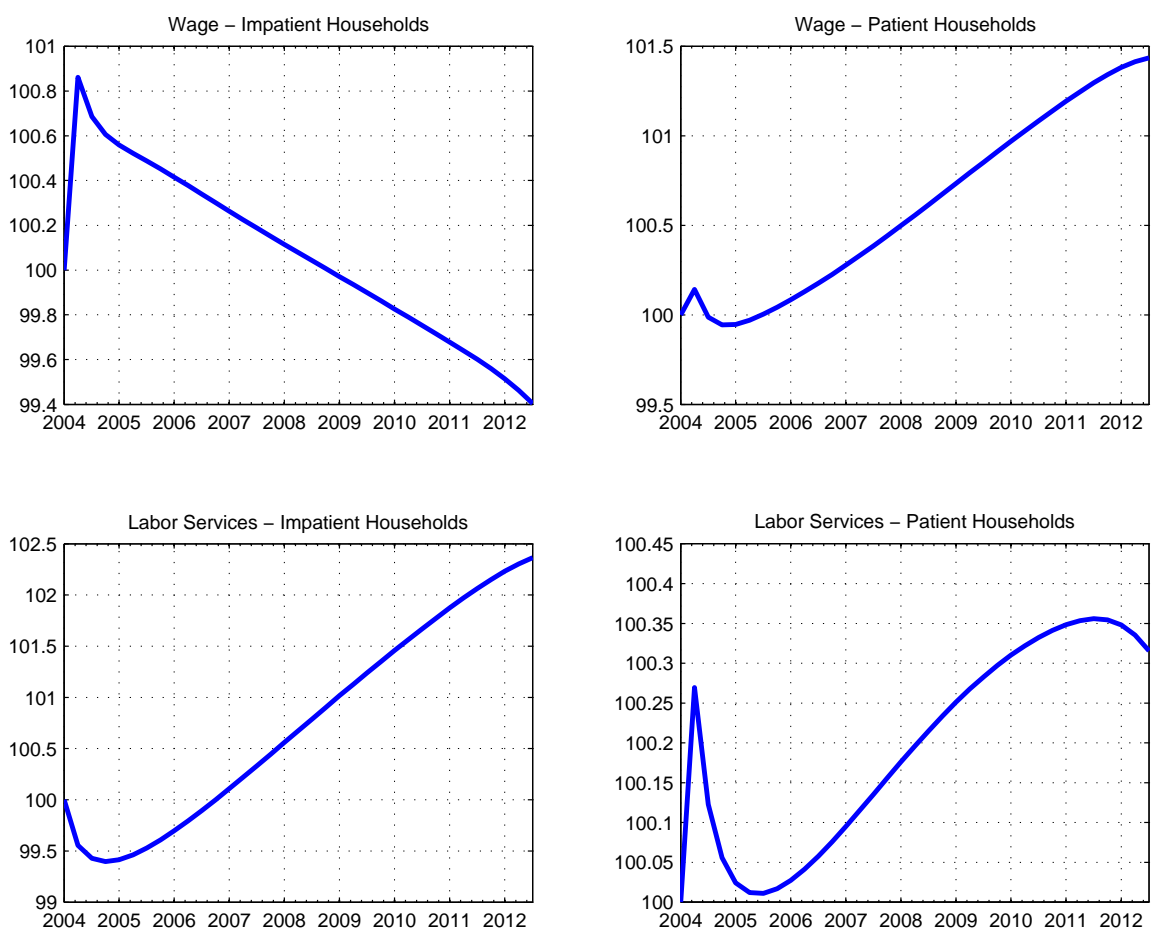

Figure 1.7: Credit deepening experiment: labor market outcomes.

evolves, impatient households have an extra motive to supply labor in order to further relax their credit constraints.
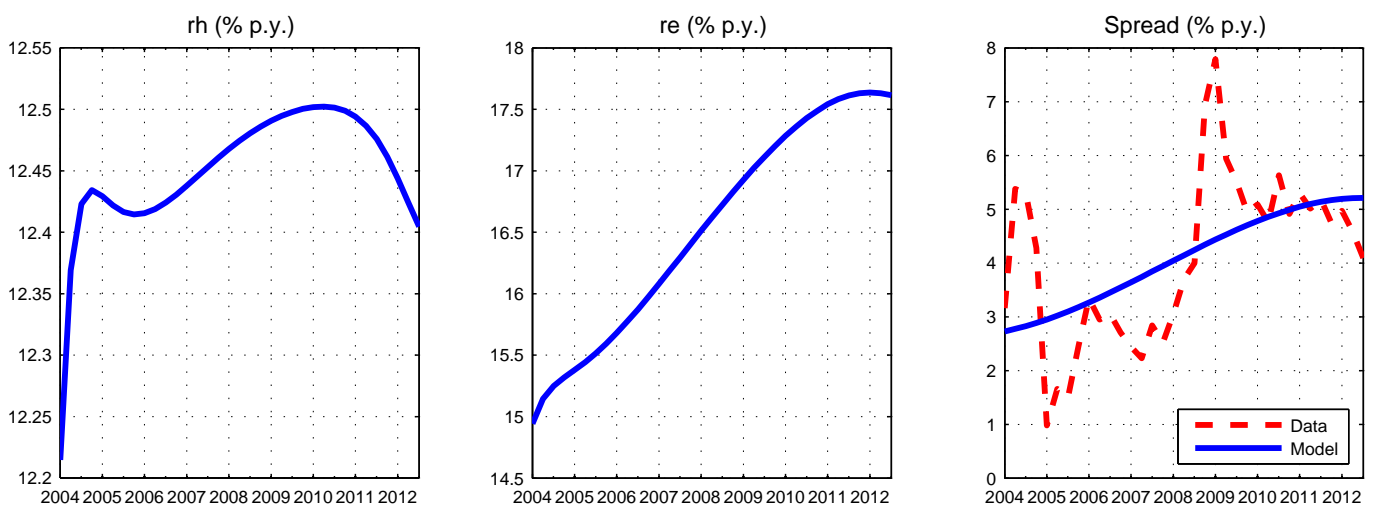

Figure 1.8: Credit deepening experiment: financial market outcomes. The spread is calculated using the SELIC rate, which is the overnight rate in the interbank market targeted by monetary policy, and the Brazilian prime rate, which averages interest rates on loans made to firms that are considered preferential borrowers. For more details on the computation of the Brazilian prime rate, see www.bcb.gov.br/pec/depep/spread/REBC_2011.pdf. Source: Brazilian Central Bank, available at www.bcb.gov.br.

Figure 1.8 shows the evolution of interest rates as well as the spread. After an initial increase of 0.2 percentage point, the interest rate accrued on deposits 
fluctuates a bit around 12.3-12.5 percent. As the credit deepening process evolves, the interest rate faced by entrepreneurs and, thus, the spread increases substantially. Intuitively, as entrepreneurs get into debt, the intermediation costs to generate these funds increase, yielding higher interest rates and spreads. Notice that the model can replicate fairly well the trend of the spread observed in the data. Finally, Figure 1.9 reports the evolution of average household debt to annual income. Again, the model can replicate fairly well the trend observed in the data.

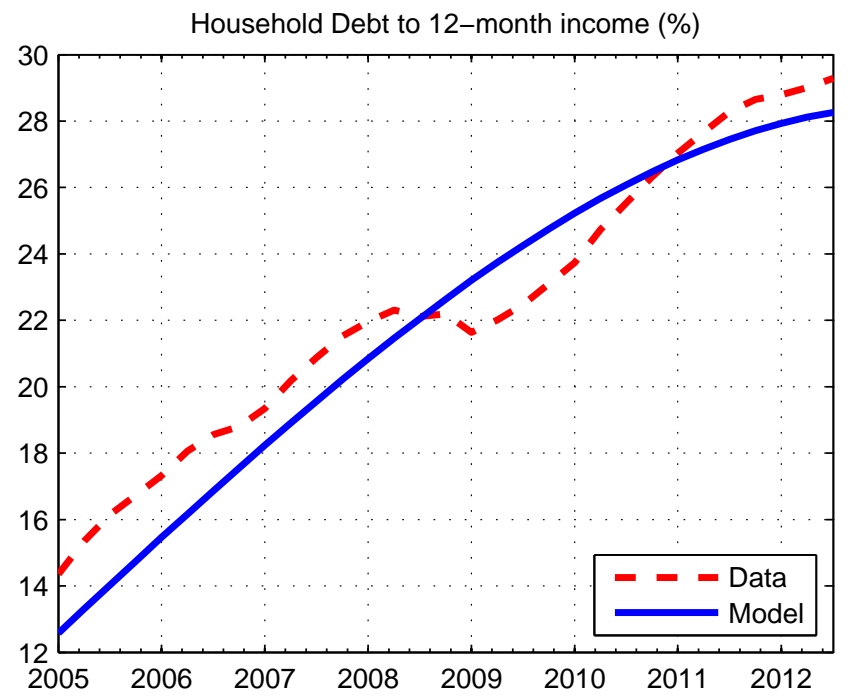

Figure 1.9: Credit deepening experiment: ratio of household debt to annual income. Household debt considers only non-earmarked funds held by financial institutions. Annual income is disposable income accumulated over the past twelve months. Source: Central Bank of Brazil, available at www.bcb.gov.br.

Hence, our modeling of the financial sector accounts for the dynamics of these two keys financial variables, which reinforces our conclusion that the credit deepening process itself cannot explain the bulk of economic growth in Brazil during the 2000s.

\subsection{3}

\section{Sensitivity analysis}

In our calibration procedure, we set $\beta^{e}, \beta^{i}, \gamma$ and $\eta$ to favor the hypothesis that the credit deepening process boosts economic growth. In this section, we show that, even more extreme calibrations of these parameters fail to generate sizeable effects on consumption, investment and product growth. Also, we show that by considering a transition that matches the paths of credit variables pointwise, our conclusions do not change. 
Finally, results barely change once we vary the impatient labor share, $\theta$, from 0.5 to 0.8 ; and the capital share, $\alpha$, from 0.4 to 0.5 (not reported but available upon request).

Borrower impatience We vary the discount factors of the borrowers, $\beta^{e}=\beta^{i}$, and analyze its effect on the paths for consumption, investment, product and inflation. Results are reported in Figure 1.10. Notice that the lower $\beta^{e}$ and $\beta^{i}$ are, the higher is the impact of the credit deepening process. Under the extreme assumption of $\beta^{e}=\beta^{i}=0.85$, which is associated with an annual "personal interest rate" of 100 percent, GDP, consumption and investment grow nearly 4, 2 and 6 percent, respectively, between 2004 and 2012. These figures are substantially higher than their counterparts in the benchmark calibration, but still relatively small once considered the long horizon between 2004 and 2012.
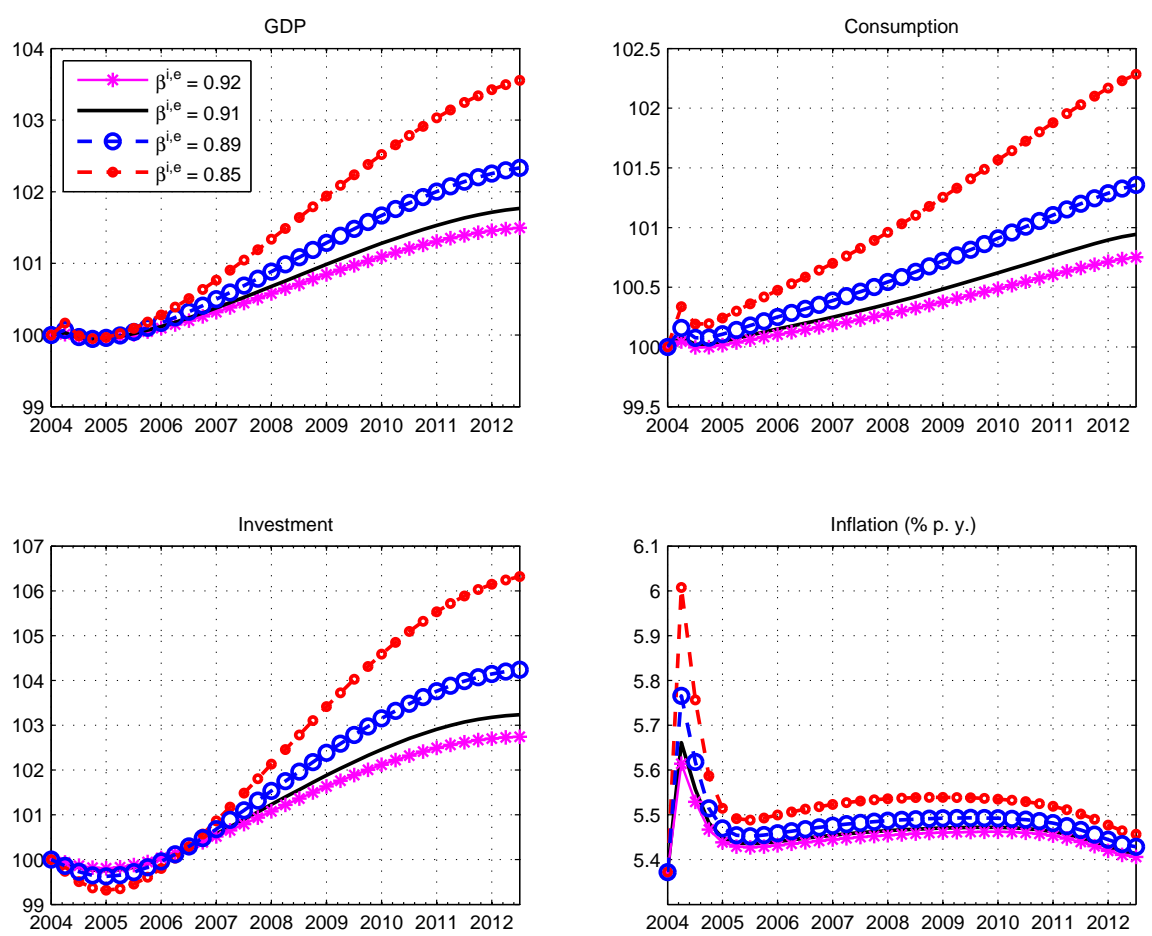

Figure 1.10: Sensitivity analysis: $\beta^{e}$ and $\beta^{i}$.

Spread As we argue above, a spread of 4.08 percent might be too low. Hence, we vary separately the parameters $\gamma$ and $\eta$, associated with the financial intermediary technology, in order to inspect how results change with different levels of spread. Results are reported in Figures 1.11 and 1.12. Notice that higher and, perhaps, more realistic levels of spread are associated with even smaller macroeconomic effects of the credit deepening process. Similarly, lower levels of spread amplify its macroeconomic effects. Intuitively, spreads are 
positively associated with intermediation costs and, which drain resources from the economy.
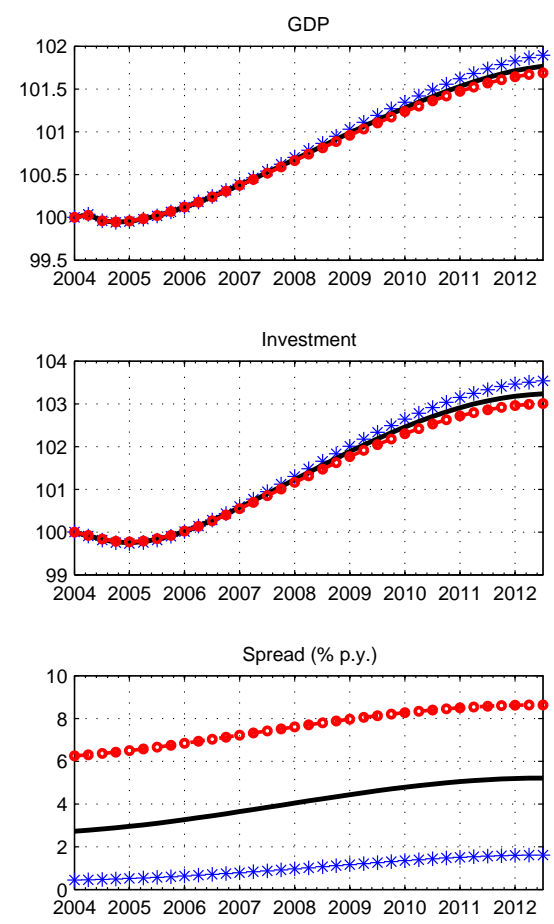
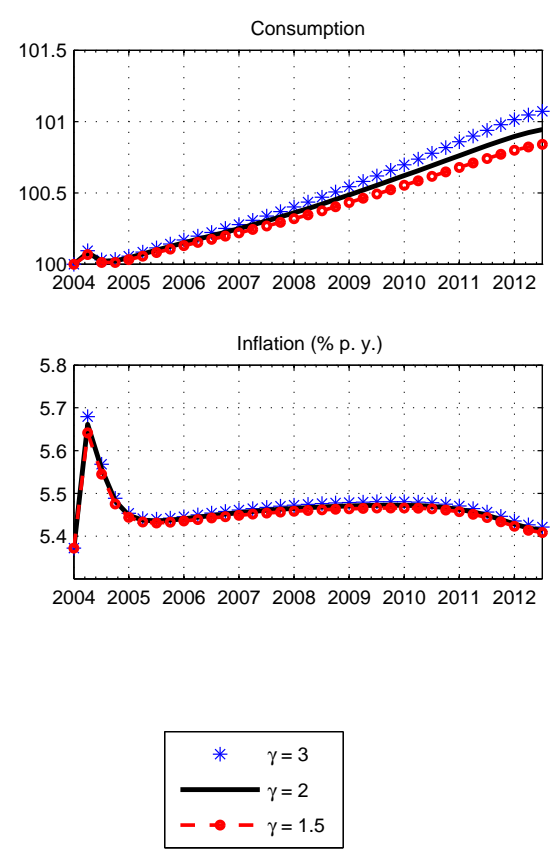

Figure 1.11: Sensitivity analysis: $\gamma$.
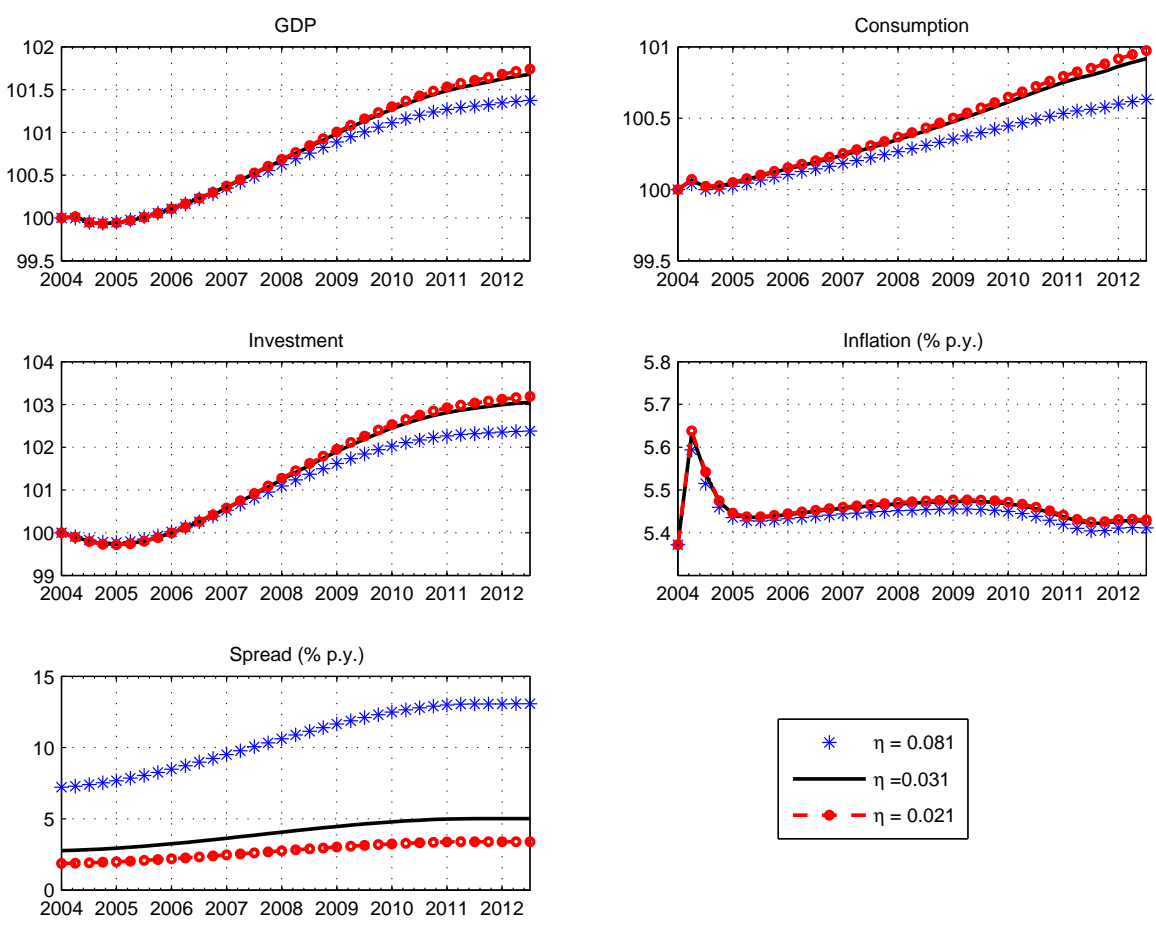

Figure 1.12: Sensitivity analysis: $\eta$. 
Non-smooth transition Finally, we consider a transition between steadystates, in which the paths of $\tau_{t}^{W L}, \tau_{t}^{S}$, and $\tau_{t}^{K}$ are chosen to fit the trajectories of the credit variables pointwise (see Figure 1.13). Figure 1.14 shows the transition paths for the macroeconomic variables, which are more volatile in this case. Importantly, this non-smooth transition does not change our conclusion that, through the lens of the model, the macroeconomic effects of the credit deepening process we observe in Brazil are modest.
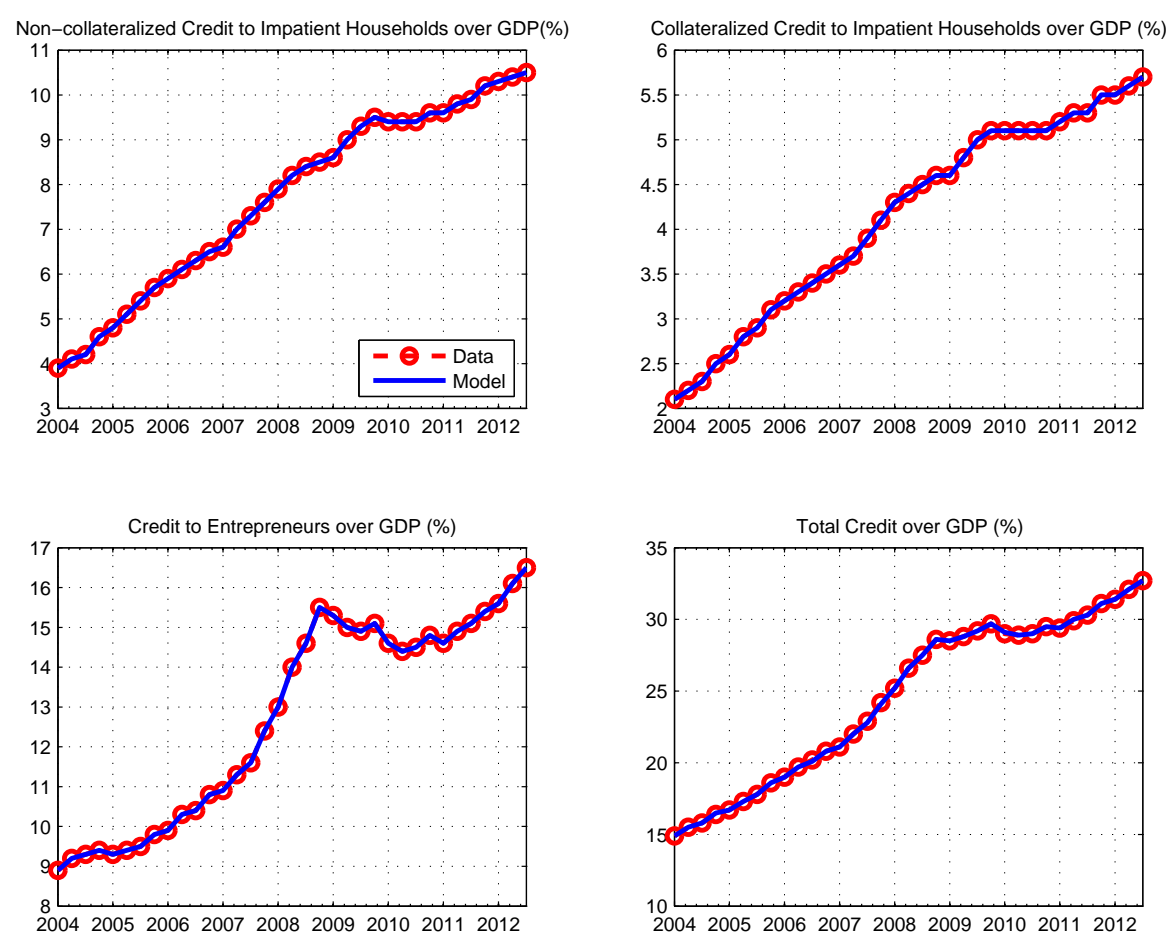

Figure 1.13: Credit deepening experiment (non-smooth): credit variables (data and model). 

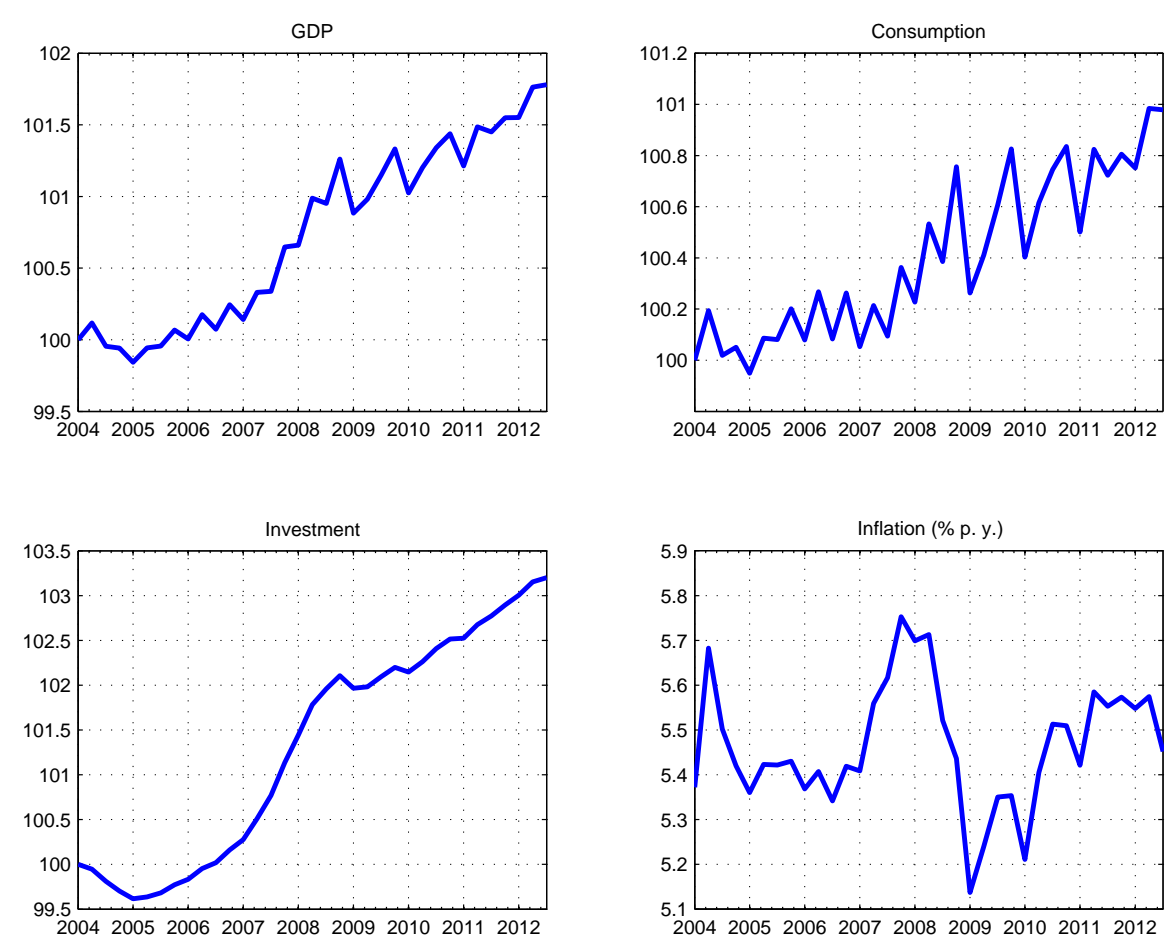

Figure 1.14: Credit deepening experiment (non-smooth): macro variables (model).

\subsection{4}

\section{Impulse response functions before and after the credit deepening}

In this section, we evaluate the propagation mechanisms of two shocks in a stochastic version of the model. In particular, we compare impulse response functions to technology and monetary policy shocks (which we add to the model for this exercise only) around two steady-states, with low and high levels of credit.

In the first steady-state, we calibrate $\tau^{W L}=0.28$ to match the ratio of individual non-collateralized credit to GDP of 4 percent, $\tau^{S}=0.07$ to match the ratio of individual collateralized credit to GDP of 2 percent, and $\tau^{K}=0.031$ to match the ratio of firm credit to GDP of 9 percent. These figures correspond to the amount of credit we observe in the Brazilian economy at the beginning of 2004 (see Figure 1.2), when the credit deepening process described above arguably started. This is the steady-state with low credit-to-GDP ratio.

In the second steady-state, we calibrate $\tau^{W L}=0.759$ to match the ratio of individual non-collateralized credit to GDP of 10 percent, $\tau^{S}=0.175$ to match the ratio of individual collateralized credit to GDP of 6 percent, and $\tau^{K}=0.057$ to match the ratio of firm credit to GDP of 16 percent. These figures are close to the amount of credit we observe in the Brazilian economy by mid-2012 (see Figure 1.2). Although it is not clear whether the credit deepening 
process we observe in Brazil is over, we set this calibration to represent the steady-state with high credit-to-GDP ratio.

Finally, we assume that the technology shock follows an $\mathrm{AR}(1)$ process with an autocorrelation coefficient of 0.91, as in De Castro et al. (2001).

Figures 1.15 and 1.16 plot the impulse response functions for selected variables (GDP, consumption, investment, household interest rate, and inflation) to both the technology and monetary policy shocks, respectively.
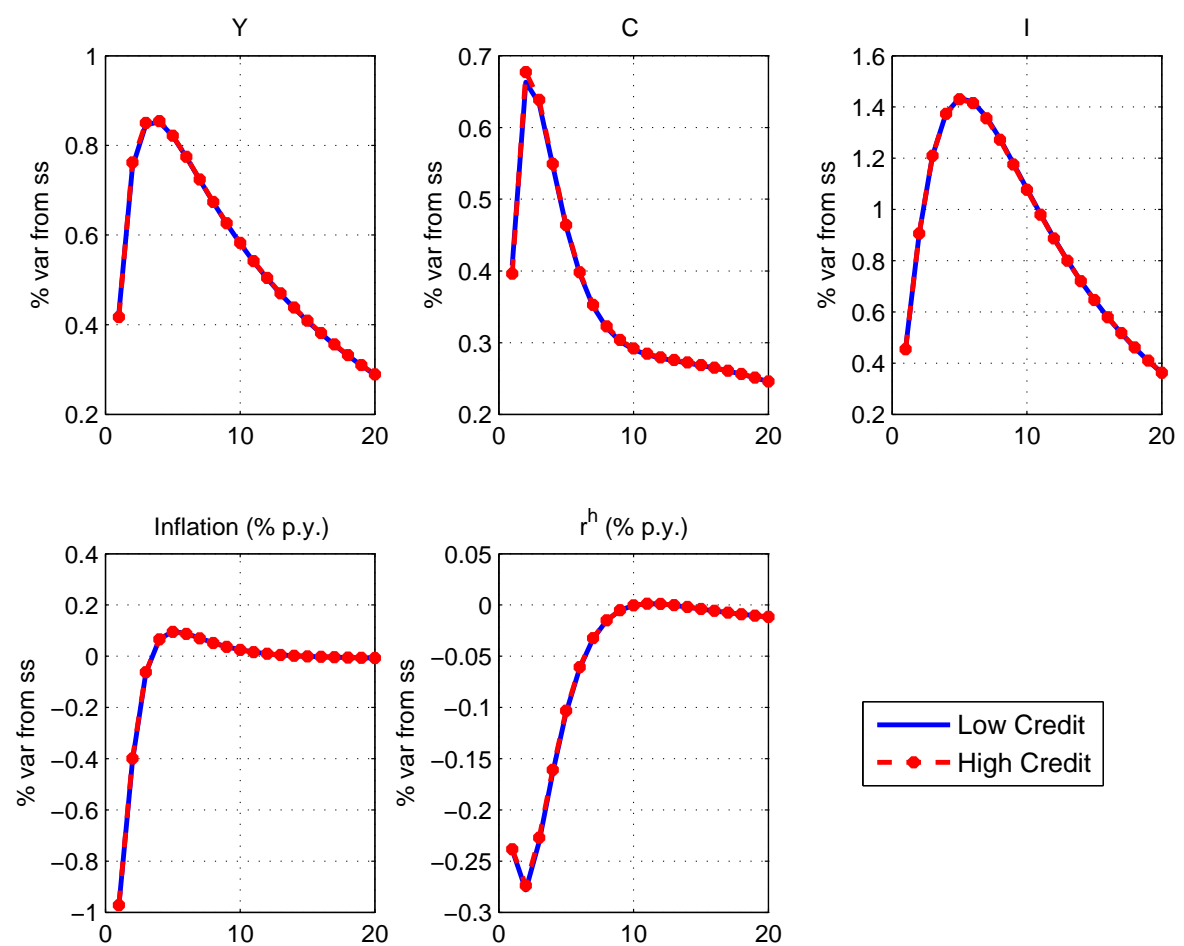

Figure 1.15: Impulse response functions for selected variables to a technology shock.

Regarding the response to a technology shock, notice that the impulse response functions in both economies (with low- and high-credit) overlap almost perfectly (Figure 1.15). This result is in congruence with the previous literature, which argues that credit constraints do not propagate a technology shock. See, for instance, Section IV.4 of Liu et al. (2013) and the references therein. The authors argue that a technology shock does not have meaningful effects on asset prices, which are the key variables to determine the degree of slackness (or tightness) of the credit constraints. Similarly, the impulse response functions to a monetary policy shock in both economies (with lowand high-credit) overlap almost perfectly (Figure 1.16).

Importantly, this overlapping of the impulse response functions to these keys shocks suggests that business cycle moments across economies would barely change. 

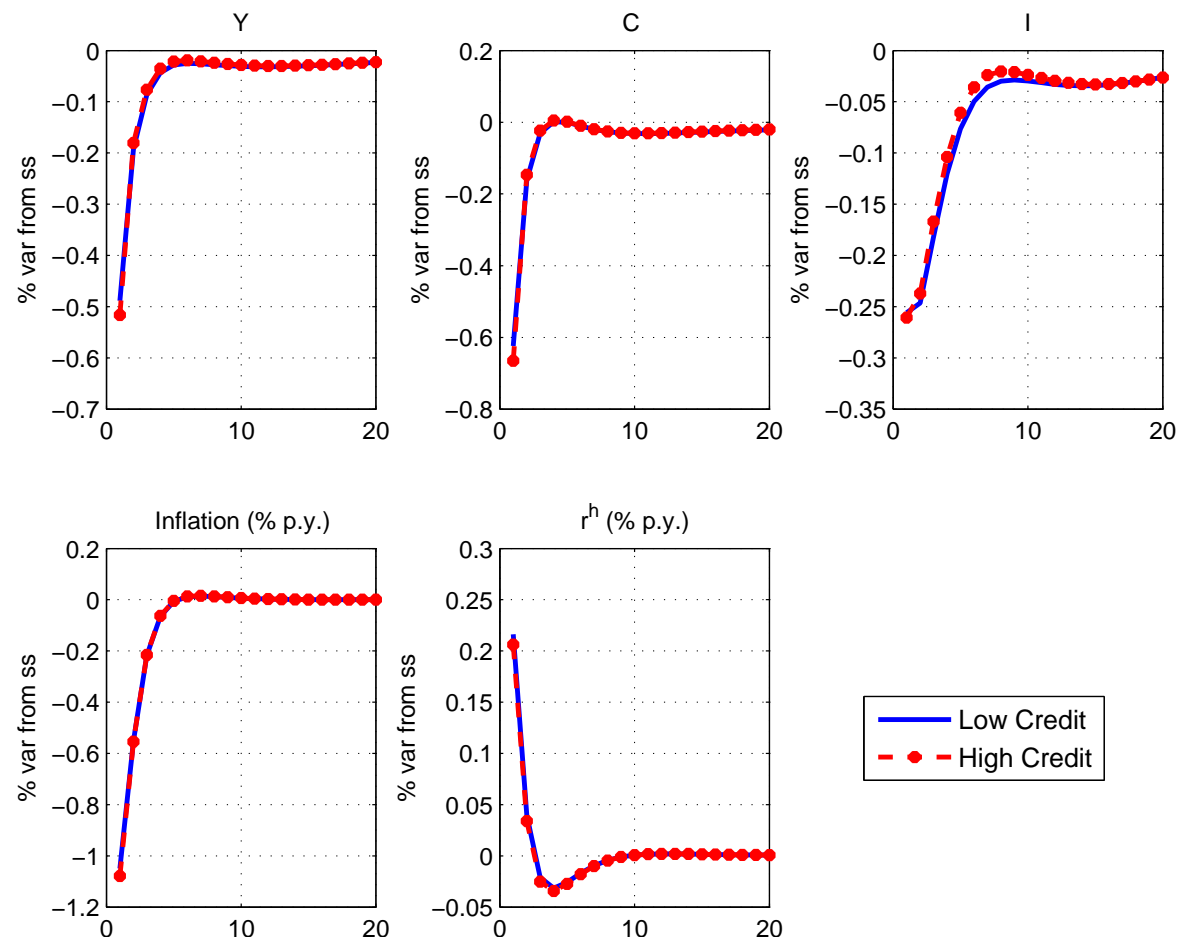

Figure 1.16: Impulse response functions for selected variables to a monetary policy shock.

\section{5}

\section{Conclusion}

In this paper, we calibrate a relatively standard New Keneysian DGE, augmented with financial frictions, to study the macroeconomic effects of the credit deepening process experienced recently by Brazil. We conclude that, even under extreme calibrations chosen to favor the hypothesis that these expansions boost economic growth, the effects on macroeconomic variables are modest.

We advance one plausible interpretations for this result. There might be a missing ingredient in the model that potentializes the role of credit deepening processes. The almost perfect overlapping of impulse response functions to technology and monetary policy shocks across two steady-states (with lowand high-credit) echoes this interpretation. ${ }^{15}$

One possible extension, as in Justiniano et al. (2014), is to consider a small open economy, in which the supply of credit is perfectly elastic at a given interest rate. In this case, macroeconomic effects can be amplified as an expansion of the demand for credit by impatient households and entrepreneurs does not need to be compensated by higher savings of patient households.

${ }^{15}$ These interpretations are not necessarily mutually exclusive. Garcia (2013), for instance, argues that sterilized foreign exchange purchases under inflation targeting can expand loans and deposits. 
Moreover, in a small open economy model, the trajectory of terms of trade can be inputted exogenously in the model. Hence, a horse race aiming to explain economic growth between surges in commodity prices and credit deepening processes is possible. We leave these questions for future research. 


\section{2 \\ Consumption Boom and Credit Deepening: The Role of Inequality ${ }^{1}$}

\section{1 \\ Introduction}

Does income inequality play a role in the association between the variation of credit and consumption growth? It is not clear a priori how the relationship between income inequality, credit and consumption growth works. In this paper, we address this question through two approaches. First, we document, through cross-country and panel estimations, that the association between consumption growth and credit expansion is stronger in countries with higher income inequality. Second, we use a Aiyagari model to check in which extent this theoretical framework can rationalize the empirical finding. We choose this model because it is the workhorse macroeconomic model used to study quantitatively the interactions between inequality and macroeconomic outcomes. Our interest is in the role of income inequality on the response of consumption to a credit deepening.

We consider an incomplete markets model with heterogeneous households, idiosyncratic risk and borrowing constraints. The mechanism behind our theoretical model is the following: a loosening of credit constraints mitigates precautionary motives, inducing households to reduce savings along the transition path to the new steady-state. Hence, consumption grows more rapidly in the short-run. This consumption boom is amplified in economies with more households close to the borrowing constraint.

Since we are interested in the role of income inequality on the response of consumption to a credit deepening, we consider three sources of income inequality in our model: the variance of the idiosyncratic risk, fiscal policy and the households' fixed level of human capital. They have different implications for the extent to which households are credit constrained in equilibrium.

Our quantitative experiment consists of analyzing, for each source of income inequality, the consumption response to an exogenous credit deepening

\footnotetext{
${ }^{1}$ This is a joint work with Laura Souza.
} 
in economies with different levels of income inequality. We consider a benchmark economy calibrated to match Brazil and its credit deepening process, that occurred between 2004 and 2012. We also consider two economies: one with lower income inequality and the other with higher income inequality than the benchmark. In each case, we change only one source of income inequality and we set the others in the same level as in the benchmark economy.

Table 2.1: Results - Summary of main results

\begin{tabular}{c|c|c}
\hline \hline \multicolumn{3}{c}{ Consumption per capita peak growth } \\
Benchmark economy: $2.3 \%$ \\
\hline Source of Inequality & Higher Inequality & Lower Inequality \\
\hline Households' lowest fixed level of human capital & $2.5 \%$ & $2.3 \%$ \\
Variance of the idiosyncratic risk & $2.3 \%$ & $3 \%$ \\
Fiscal policy & $2 \%$ & $2.5 \%$ \\
\hline \hline
\end{tabular}

Table 2.1 summarizes our main results. ${ }^{2}$ The consumption growth at the peak in the benchmark economy is 2.3 percent. We show that when the source of income inequality comes from households' lowest fixed level of human capital, our model can rationalize the empirical evidence. In this case, the economy with higher income inequality grows at the peak 2.8 percent and the one with lower inequality, 2.3 percent. Once other sources of income inequality are considered, the opposite occurs.

This paper is organized as follows. Section 2.2 presents the empirical evidence, including the related literature and data description. In section 2.3, we describe our model and we also include the related literature to this framework and the description of our experiment. In section 2.4, we present our calibration strategy and our main results. Finally, section 2.5 concludes.

\section{2}

\section{Empirical Evidence}

\subsection{1}

\section{Related literature}

Our work is related to a vast literature that has been studying the relation between initial inequality, typically measured by the Gini index, and subsequent economic growth. Alesina and Rodrik (1994) and Persson and Tabellini (1994) found a negative association through a cross-country estimation. Whereas Forbes (2000), estimating a panel with fixed effects, found

\footnotetext{
${ }^{2}$ In these results, all economies have the same initial debt-to-GDP ratio. For more details, see subsection 2.4.2.
} 
a positive relationship between initial inequality and subsequent growth in the short run and negative in the long run.

Moreover, there is a literature that has focused on the role of poverty on economic growth. Ravallion (2012) evaluates the relationship between growth (measured by consumption) and initial poverty, using a new database for a set of developing countries. His results suggest that there is an adverse effect of high initial poverty on growth and high initial poverty dulls the impact of growth on poverty. Ravallion also shows that high initial inequality matters to growth and poverty reduction if it entails a high incidence of poverty relative to the mean.

Another strand of the literature that has incorporated credit-market failures suggests that high inequality reduces economy's aggregate efficiency and, therefore, it reduces growth. For example, Banerjee and Newman (1993) and Aghion and Bolton (1997) found that inequality lead to lower economic growth due to credit market imperfections. They argued that in the short run the relationship might be positive, but in the long run, more income inequality hampered economic growth. Galor and Zeira (1993) show, using a theoretical model, that in the presence of credit-market failures and indivisibilities in investment in human capital, the initial distribution of wealth affects aggregate output and investment both in the short and in the long run, as there are multiple steady states. Finally, Ravallion (2001, 2007) argues intuitively that poverty retards growth when there are credit market failures.

There has been considerable interest between economists in the idea that, for various reasons, inequality could actually reduce growth. Recently, this line of inquiry was brought into focus by the latest financial crisis, that has led to a vigorous debate if widening inequality was one of the causes of the crisis. For example, Pegurini et al. (2013), using a panel estimation, finds a statistically significant and positive relationship between income concentration and private sector indebtedness when controlling for conventional credit determinants. This result calls attention for the importance of the distribution of income to macroeconomics outcomes.

Unlike the literature mentioned, the purpose of this paper is to analyze if income inequality plays a role in the association between consumption growth and credit expansion. For such purpose, we use cross-country and panel estimations. Our results show that the association between consumption growth and credit expansion is stronger in countries with higher income inequality. 


\subsection{2}

Data

We use anual data. Our dependent variable is average growth of household consumption per capita, which is available at the World Bank. Household final consumption expenditure per capita (private consumption per capita) is calculated using private consumption in constant 2005 prices and World Bank population estimates.

We use the Gini index to measure income or consumption inequality in each country, it measures the extent to which the distribution of income or consumption expenditure among households within an economy deviates from a perfectly equal distribution. ${ }^{3}$ We choose to use two datasets of Gini indexes. ${ }^{4}$ The first one is constructed by Ravallion (2012). The autor calculates income inequality using directly primary data from household surveys for ninety two developing and transition countries. This method eliminates some of the inconsistencies and comparability problems found in existing data compilations from secondary sources. The other dataset is a compilation made by United Nations University - World Institute for Development Economics Research (UNU-WIDER) that ranks available Gini indexes by the quality of their sources and methods.

At last, for credit data, we use use two datasets. The first one is from the Financial Access Survey (FAS) developed by International Monetary Fund (IMF). This survey collects annual data on access to and usage of financial services around the world, from 2004 to 2011. We consider only household outstanding loans with commercial banks. The other database is from World Bank which is the domestic credit to private sector, that is bigger than the IMF database. For this reason, we use the domestic credit to private sector to construct the panel data.

\subsection{3}

\section{Results}

In this section we provide evidence on the link between the average consumption per capita growth and the interaction between initial inequality and the variation of credit. We estimate the following regression:

\footnotetext{
${ }^{3}$ A Gini index of 0 represents perfect equality, while an index of 100 implies perfect inequality.

${ }^{4}$ Unlike national accounts data which are in principle comparable across countries, there is no agreed basis of definition for the construction of distribution data. Sources and methods might vary, especially across but also within countries. This may be the case even if the data comes from the same source.
} 
Cgrowth $_{t: T}=\alpha+\beta_{1} \ln \left(c_{t}\right)+\beta_{2}$ gini $_{t}+\beta_{3}$ credit $_{t}+\beta_{4} \Delta_{T-t}$ credit $\beta_{5}$ gini $_{T-t}$ credit $\varepsilon_{t}$

The dependent variable $C g r o w t h_{t: T}=\frac{100\left[\ln \left(c_{T}\right)-\ln \left(c_{t}\right)\right]}{T-t}$ is the average consumption per capita growth rate between years $t$ and $T$. We follow a extensive literature of economic growth to choose our controls, especially, Alesina and Rodrik (1994) and Person and Tabellini (1994): gini $t_{t}$ is the income Gini index for year $t ;^{5}, \ln \left(c_{t}\right)$ is the consumption per capita in year $t$ and credit $_{t}$ is the initial credit to GDP ratio. The main difference from other studies is that we consider the variation of credit between years $t$ and $T\left(\Delta_{T-t}\right.$ credit $)$ and the interaction between $\Delta_{T-t}$ credit and gini $_{t}$, because we are interested to show that inequality plays a roll in the relation between consumption growth and the variation of credit.

Table2.2 shows the results. In the first two columns, we consider the Gini index constructed by Ravalion (2012) and the credit to households from IMF. In this case, our sample consists of thirty one developing countries and the initial and final years are 2004 and 2007, respectively. In column 1, we do not include the interaction gini $\Delta_{T-t}$ credit, hence the coefficient of the variation of credit $\left(\beta_{4}\right)$ is positive and significant at 1 percent. On the other hand, in column 2 , we introduce the interaction and its coefficient $\left(\beta_{5}\right)$ is positive and significant at 5 percent but the coefficient of the variation of credit becomes negative and insignificant. This result suggests that initial income inequality of countries in 2004 intensifies the association between the variation of credit and average consumption per capita growth between 2004 and $2007 .{ }^{6}$ The average Gini index in this sample is 39.25 , thus the correlation estimated between credit expansion and consumption growth is approximately 0.57 , all other variables remain constant. This is our main evidence because we use the best source of Gini index and household debt data.

In order to check whether the results are robust, we repeat the same regressions in columns 1 and 2 using different databases. We also present a panel specification. In columns 3 and 4, we use the Gini index calculated by UNU-WIDER and the credit to households from IMF. Then our sample consists of fifty countries and we considered the same years as before (2004 and 2007). Note that the results persist: the coefficient of the interaction between $\Delta_{T-t}$ credit and gini $_{t}$ is positive and significant at 5 percent and the coefficient of the variation of credit becomes negative and insignificant once the interaction is considered.

In columns 5 and 6 , we also consider the Gini index from UNU-WIDER

\footnotetext{
${ }^{5}$ See literature section.

${ }^{6}$ Note that we are not interested in the size of the estimated coefficients. Our interest lies only on their signals.
} 
but we use the domestic credit to the private sector from World Bank, which is a good proxy for household credit, the correlation coefficient between these series is greater than 0.7. This occurs because household credit is in the private sector credit. In this case, we have ninety three countries and the initial and final years are 2000 and 2007, respectively. Most of the results are maintained, but the coefficient of the variation of credit is negative and significant at 10 percent once the interaction gini $\Delta_{T-t}$ credit is considered.

Furthermore, we show that the evidence presented above persists once we use a panel estimation with fixed-effects for years and countries. These results are in columns 7 and 8 . Our sample consists of thirty one countries and we considered four windows of five years between 1990 and 2009. In this specification, we also use the Gini index calculated by UNU-WIDER and the domestic credit to private sector from World Bank. Note that the coefficient of the interaction between $\Delta_{T-t}$ credit and ginit is positive and significant at 10 percent, but it is smaller than the cross-section estimations.

In conclusion, we find robust evidences that the association between average consumption per capita growth and the variation of credit is stronger in countries with higher income inequality. In the following section, we provide a theoretical framework and we test if this model can corroborate the empirical finding.

Table 2.2: Empirical Evidence

\begin{tabular}{|c|c|c|c|c|c|c|c|c|}
\hline \multicolumn{3}{|c|}{ "Ravallion (2012) } & \multicolumn{6}{|c|}{ בUNU-WIDER } \\
\hline & (1) & $(2)$ & (3) & (4) & $(5)$ & (6) & $(7)$ & (8) \\
\hline VARIABLES & $04-07$ & $04-07$ & $04-07$ & $04-07$ & $00-07$ & $00-07$ & $90-09$ & $90-09$ \\
\hline ginivarcreditHH & & $\begin{array}{c}0.0350 * * \\
(0.0151)\end{array}$ & & $\begin{array}{r}0.0180^{* *} \\
(0.00794)\end{array}$ & & & & \\
\hline ginivarcreditDO & & & & & & $\begin{array}{c}0.00280^{* * *} \\
(0.00106)\end{array}$ & & $\begin{array}{c}0.00157^{*} \\
(0.000828)\end{array}$ \\
\hline consupinitial & $\begin{array}{l}-0.812 \\
(0.532)\end{array}$ & $\begin{array}{l}-0.524 \\
(0.531)\end{array}$ & $\begin{array}{c}-1.347^{* * *} \\
(0.487)\end{array}$ & $\begin{array}{c}-1.154^{* *} \\
(0.506)\end{array}$ & $\begin{array}{c}-0.666^{* *} \\
(0.294)\end{array}$ & $\begin{array}{c}-0.588^{* *} \\
(0.295)\end{array}$ & $\begin{array}{c}-8.849^{* *} \\
(3.589)\end{array}$ & $\begin{array}{c}-8.976^{* *} \\
(3.452)\end{array}$ \\
\hline giniinitial & $\begin{array}{c}0.0533 \\
(0.0639)\end{array}$ & $\begin{array}{l}-0.0823 \\
(0.0685)\end{array}$ & $\begin{array}{c}0.0741 \\
(0.0597)\end{array}$ & $\begin{array}{c}0.0203 \\
(0.0554)\end{array}$ & $\begin{array}{l}-0.0137 \\
(0.0244)\end{array}$ & $\begin{array}{l}-0.0420 \\
(0.0256)\end{array}$ & $\begin{array}{c}0.0339 \\
(0.0492)\end{array}$ & $\begin{array}{c}0.0196 \\
(0.0448)\end{array}$ \\
\hline credGDPinitialHH & $\begin{array}{l}-0.0392 \\
(0.0718)\end{array}$ & $\begin{array}{l}-0.0519 \\
(0.0690)\end{array}$ & $\begin{array}{l}-0.0429 \\
(0.0328)\end{array}$ & $\begin{array}{l}-0.0424 \\
(0.0341)\end{array}$ & & & & \\
\hline varcreditHH & $\begin{array}{r}0.548^{* * *} \\
(0.0861)\end{array}$ & $\begin{array}{r}-0.804 \\
(0.619)\end{array}$ & $\begin{array}{c}0.328^{* * *} \\
(0.111)\end{array}$ & $\begin{array}{c}-0.271 \\
(0.213)\end{array}$ & & & & \\
\hline credGDPinitialDO & & & & & $\begin{array}{l}-0.0120^{*} \\
(0.00679)\end{array}$ & $\begin{array}{l}-0.0128^{*} \\
(0.00681)\end{array}$ & $\begin{array}{l}-0.0159^{* *} \\
(0.00749)\end{array}$ & $\begin{array}{l}-0.0119^{*} \\
(0.00700)\end{array}$ \\
\hline varcreditDO & & & & & $\begin{array}{c}0.0376^{* * *} \\
(0.0130)\end{array}$ & $\begin{array}{l}-0.0621^{*} \\
(0.0345)\end{array}$ & $\begin{array}{l}0.00955 \\
(0.0103)\end{array}$ & $\begin{array}{l}-0.0516 \\
(0.0310)\end{array}$ \\
\hline Constant & $\begin{array}{c}6.937 \\
(4.188)\end{array}$ & $\begin{array}{l}10.80^{* *} \\
(4.606)\end{array}$ & $\begin{array}{r}11.23^{* *} \\
(4.661)\end{array}$ & $\begin{array}{l}11.54^{* *} \\
(4.379)\end{array}$ & $\begin{array}{c}9.129^{* * *} \\
(2.720)\end{array}$ & $\begin{array}{c}9.796^{* * *} \\
(2.824)\end{array}$ & $\begin{array}{l}72.59^{* *} \\
(29.90)\end{array}$ & $\begin{array}{l}73.83^{* *} \\
(28.70)\end{array}$ \\
\hline Observations & 31 & 31 & 50 & 50 & 93 & 93 & 124 & 124 \\
\hline R-squared & 0.493 & 0.562 & 0.290 & 0.319 & 0.242 & 0.285 & 0.294 & 0.317 \\
\hline $\mathrm{F}$ test model & 11.80 & 24.84 & 7.458 & 8.625 & 5.563 & 4.989 & 3.276 & 3.127 \\
\hline Number of countries & & & & & & & 31 & 31 \\
\hline
\end{tabular}




\section{3}

\section{Model}

Our model is related to papers that consider incomplete markets with heterogeneous agents, idiosyncratic risk and borrowing constraint, such as Aiyagari (1994) and Bewley (1977).

Recently, Guerrieri and Lorenzoni (2010), using a model à la BewleyHuggett, evaluate the effects of a credit tightening on consumer spending and aggregate output. Their results show that overly indebted agents reduce their spending and increase their labor supply. But the precautionary motive is strong enough that the reduction in consumer spending dominates. As a result, there is a decrease in the aggregate output that causes recession.

\subsection{1}

\section{The baseline model}

Our model is based on Aiyagari (1994). Our aim is to study the consumption response to a credit deepening in economies with different levels of income inequality.

\section{Endowments}

There is a continuum with unit mass of households who live infinitely and faces idiosyncratic income uncertainty. Households differ in their labor endowments. There are two channels that contribute to determinate the total efficiency units supplied by the households to the labor market. First, there is a stochastic component $s_{t}$ that is the efficiency units of labor whose log follows a finite state Markov chain, which is approximated by a stationary $\operatorname{AR}(1)$ process $\log \left(s_{t}\right)=\rho \log \left(s_{t-1}\right)+\varepsilon_{t}$ with $\varepsilon_{t} \sim N\left(0, \sigma_{\varepsilon}^{2}\right)$. Second, there is a fixed component $\theta \in\left\{\theta_{1}, \theta_{2}, \theta_{3}, \theta_{4}\right\}$, that is the household level of human capital drawn by nature from a distribution in which each $\theta$ has mass $\mu_{\theta}$ and $\sum_{\theta} \mu_{\theta}=1$.

The total efficiency units that a household is endowed is the product of these two components, and labor earnings are given by $w \theta s_{t}$, where $w$ is the wage per efficiency unit.

\section{Preferences}

Preferences are described by:

$$
E_{0} \sum_{t=0}^{\infty} \beta^{t} U\left(c_{t}\right)
$$


The future is discounted at rate $\beta \in(0,1)$. We assume that $U\left(c_{t}\right)=$ $\ln \left(c_{t}\right)$.

\section{Production technology}

There is a representative firm that produces consumption goods with a Cobb-Douglas function:

$$
f\left(k_{t}, n_{t}\right)=k_{t}^{\alpha} n_{t}^{1-\alpha}
$$

where $\alpha \in(0,1), k_{t}$ and $n_{t}$ are aggregate capital and efficient labor units, respectively.

Each period, capital depreciates at the exogenous rate $\delta$ and the firm hires capital and labor from competitive markets.

The problem of the representative firm is given by:

$$
\max _{n_{t}, k_{t}} f\left(k_{t}, n_{t}\right)-w_{t} n_{t}-\left(r_{t}+\delta\right) k_{t}
$$

The first order conditions of the firm provide the expressions for the net real return of capital $r_{t}$ and the wage rate per efficiency unit $w_{t}$ :

$$
\begin{gathered}
f_{k}\left(k_{t}, n_{t}\right)-\delta=r_{t} \\
f_{n}\left(k_{t}, n_{t}\right)=w_{t}
\end{gathered}
$$

\section{Government}

We consider that the government taxes linearly labor income through a tax rate given by $\tau$. We also assume that the government does not have any expenditure, thus all his funds are rebated as a lump-sum transfer $T$ to each household. For each period $t$, the government budget constraint is given by:

$$
\tau w_{t} n_{t}=T_{t}
$$

\section{Other market arrangements}

There are no insurance markets for the idiosyncratic shock, but households can self-insure by saving through the risk-free asset. Moreover, there is an exogenous borrowing limit, $\underline{b}>0$, which is tighter than the natural limit. Hence, in our model, markets are incomplete in the sense that households can smooth consumption by borrowing and lending only through one type of asset.

We also consider a small open economy in the financial market and closed in the labor market. Thus, at each period, the interest rate $r$ is exogenously determined in the international capital market, but the wage rate $w$ clears the domestic labor market. 


\subsection{2}

\section{Stationary equilibrium}

Our focus is on the properties of a stationary competitive equilibrium in which the measure of agents, defined over an appropriate family of subsets of the individual state space, remains invariant over time.

\section{Households' problem}

The value function of a household with current asset holdings $a$, current labor endowment $s$ and fixed level of human capital $\theta$ is denoted by $V(a, s ; \theta)$. The household problem in its recursive form can be represented as follow:

$$
V(a, s ; \theta)=\max _{c, a^{\prime}}\left\{\log (c)+\beta \sum_{s^{\prime}} V\left(a^{\prime}, s^{\prime} ; \theta\right) \Pi\left(s^{\prime}, s\right)\right\}
$$

subject to

$$
\begin{aligned}
& c+a^{\prime}=(1+r) a+w \theta s(1-\tau)+T \\
& c \geqslant 0, \quad a^{\prime} \geqslant-\underline{b}
\end{aligned}
$$

The first restriction is the budget constraint. The last set of restrictions implies that consumption is feasible and households are borrowing constrained. $s$ is an uninsured idiosyncratic risk that follows a finite state Markov chain with transition probabilities $\Pi\left(s^{\prime}, s\right)=\operatorname{Prob}\left(s_{t+1}=s^{\prime} \mid s_{t}=s\right)$, where $s, s^{\prime} \in$ $\left\{s_{1}, s_{2}, \ldots, s_{n}\right\}$.

We obtain the decision rules for consumption $c(a, s ; \theta)$ and asset holdings $a(a, s ; \theta)$ by solving the problem above.

\section{Recursive Equilibrium}

The definition of stationary competitive equilibrium is given by $[V(a, s ; \theta), c(a, s ; \theta), a(a, s ; \theta), r, w, k, n, T, \tau]$ and a distribution $\lambda(a, s ; \theta)$ such that:

(i) Given prices and government policies $(r, w, T, \tau),[V(a, s ; \theta), c(a, s ; \theta), a(a, s ; \theta)]$ are the solutions of the agent's problem. ${ }^{7}$

(ii) The wage per efficient unit and the price of capital are given by:

$$
\begin{gathered}
f_{n}(k, n)=w \\
\delta=f_{k}(k, n)-r
\end{gathered}
$$

\footnotetext{
${ }^{7}$ We use the endogenous grid point method proposed by Carroll (2006) to solve the
} household problem. 
(iii) $\lambda(a, s ; \theta)$ is a stationary distribution associated with the transition function implied by the decision of $a(a, s ; \theta)$ and the law of motion $s$ :

$$
\lambda(a, s ; \theta)=\int_{\mathbf{A} \times \mathbf{S}} P(a, s, \mathbf{a}, \mathbf{s} ; \theta) d \lambda
$$

for all $\mathbf{a} \times \mathbf{s} \subseteq \mathbf{A} \times \mathbf{S}$. The transition function $P$ is the probability that a household with state $(a, s)$ will have a state belonging to $\mathbf{a} \times \mathbf{s}$ next period.

(iv) Labor market clears:

$$
n=\sum_{\theta} \mu_{\theta} \int_{\mathbf{A} \times \mathbf{S}} \theta s \lambda(a, s ; \theta) d a d s
$$

(v) There is equilibrium in the government budget:

$$
\tau w n=T
$$

\subsection{3 \\ Description of the experiment}

In our model, there are three sources of income inequality: variance of the idiosyncratic risk $\sigma_{\varepsilon}^{2}$, fiscal policy $\{\tau, T\}$ and households' fixed level of human capital $\theta$. We are interested in analyzing the consumption response to a credit deepening in economies with different levels of income inequality. ${ }^{8}$ Therefore, we consider a benchmark economy ${ }^{9}$ and two economies: one with higher income inequality and the other with lower inequality than the benchmark. In our experiment, we analyze the consumption growth at the peak.

Since we have three different sources of income inequality, we change only one source at each experiment and we set the other sources at the benchmark level. For example, we change the variance of the idiosyncratic risk $\left(\sigma_{\varepsilon}^{2}\right)$ to generate two economies: one more and one less equal than the benchmark. Different values of $\sigma_{\varepsilon}^{2}$ modify the grid of possible values of $s_{t}$. Thus, the aggregate labor units $(n)$ is changed. If the government budget constraint is always binding (equation 11), this will change fiscal policy $\{\tau, T\}$. We are interested in analysing the isolated effect of each source of income inequality, for this reason, we set fiscal policy $\{\tau, T\}$ and households' fixed level of human capital at the same levels as in the benchmark economy. Therefore, in some

${ }^{8}$ In our experiment, we use the Gini index to measure income inequality. We consider total income before taxes to calculate this index.

${ }^{9}$ As we show in the calibration section, we consider the Brazilian economy as the benchmark. 
cases, the government's budget might not be satisfied, but it is always satisfied in the benchmark economy. ${ }^{10}$

A credit deepening in our economy is an unexpected shock that increases permanently the borrowing limit $\underline{b}$ to $\underline{b}^{\prime}$. We consider two experiments. In the first, we set the same $\underline{b}$ and $\underline{b}^{\prime}$ as in the benchmark economy. Since the economies have different levels of income inequality, their credit dynamics are different from the benchmark, which might influence our results. For this reason, we consider a second experiment in which we adjust $\underline{b}$ and $\underline{b}^{\prime}$ to match the same credit dynamics as in the benchmark economy.

\section{4}

\section{Quantitative analysis}

We analyze the consumption growth driven by a credit deepening in economies that have different levels of income inequality. There are three sources of income inequality in our model: ${ }^{11}$ the variance of the idiosyncratic risk $\sigma_{\varepsilon}^{2}$, fiscal policy $\{\tau, T\}$ and the households' fixed level of human capital $\theta$. In this section, we present the results for these three cases.

\subsection{1}

\section{Calibration: application to Brazil}

In this section, we describe our calibration strategy. Each period corresponds to one year. We choose parameters of the model to match some characteristics of the Brazilian economy. Recently, Brazil has experienced an intense credit deepening ${ }^{12}$ as in other developing countries. This process started in 2004 , thus we target data this year.

We solve the stationary recursive equilibrium of the model and the transitional dynamics numerically using the algorithm of Ríos-Rull (1999). We consider that the $\log$ of the efficiency units of labor $s_{t}$ follows a finite state Markov chain, which is approximated by a stationary $\operatorname{AR}(1)$ process $\log \left(s_{t}\right)=\rho \log \left(s_{t-1}\right)+\varepsilon_{t}$ with $\varepsilon_{t} \sim N\left(0, \sigma_{\varepsilon}^{2}\right)$. We use Rouwenhorst (1995)'s algorithm with 9 states to approximate this $\operatorname{AR}(1)$ process using a Markov chain. ${ }^{13}$ In Brazil, due to the lack of a household panel data survey, such as the Panel Study of Income Dynamics in the United States, we cannot estimate

\footnotetext{
${ }^{10}$ This is not a standard approach in the literature, but the results of our model are not affected by this approach.

${ }^{11}$ Note that $\rho$ is another source of inequality in the model, but changes in this parameter modify the transition probabilities. We want to compare economies with different levels of inequality and with the same transition probabilities.

${ }^{12}$ Between 2004 and 2012, the ratio of nonearmarked credit to households to GDP went from 6 percent to 16 percent.

${ }^{13} \mathrm{We}$ choose this method because is superior to the commonly used Tauchen (1986) procedure as it perfectly matches persistence of the process even for low number of states.
} 
$\rho$ properly. As an alternative strategy, we set $\rho$ based on evidence for the US economy. We follow French (2005) that estimates $\rho=0.98$ using anual data. Furthermore, we set $\sigma_{\varepsilon}^{2}=0.045$ to match the income Gini index in Brazil in 2004 .

We consider a Cobb Douglas production function. The share of capital $\alpha$ is equal to 0.4 (e.g. Paes and Bugarin (2006)) which is a common value for the Brazilian economy. The discount fator $\beta$ is set to match the annual consumption to output ratio of 0.65 , that is obtained from Instituto Brasileiro de Geografia e Estatística (IBGE).

We follow Wulff and Octávio (2010) and we set $T$ such that the annual transfers to output ratio for households of 9.41 percent as in the Brazilian economy in 2004. The government budget constraint have to be binding in the benchmark economy, and for this reason, we set the tax rate $\tau=0.15$. Furthermore, we calibrate the savings rate $r^{14}$ equal to 0.039 as in Berriel and Zilberman (2012).

We approximate $\theta$ by the ratio between the income of each level of education of the head of the household and the income of lowest one, which is a proxy for the unobserved fixed level of human capital. We consider four levels of education (1) between 0 and 3 years of schooling with $\theta_{1}=1$; (2) between 4 and 10 years of schooling with $\theta_{2}=1.70$; (3) between 11 and 14 years of schooling with $\theta_{3}=3.24$; and (4) at least 15 years of schooling with $\theta_{4}=9$. The distribution of $\theta$ is obtained from the Pesquisa Nacional por Amostra de Domicílios (PNAD) in 2005. Thus, the share of the households in each group of education is: (1) $\mu_{\theta_{1}}=0.24$; (2) $\mu_{\theta_{2}}=0.42$; (3) $\mu_{\theta_{3}}=0.25$; (4) $\mu_{\theta_{4}}=0.09$.

Finally, we choose the borrowing limit $\underline{b}$ to match the credit-to-GDP ratio of 6 percent. This value corresponds to credit with nonearmarked resources to households in 2004. This data is obtained from the Brazilian Central Bank (BCB). In our model, we compute this ratio using the sum of household's debt in economy divided by the product.

Table 2.3 summarizes this information.

Table 2.3: Benchmark economy - Brazil

\begin{tabular}{llll}
\hline \hline Parameter & Description & Value & Target \\
\hline$\alpha$ & Capital Share & 0.4 & Paes and Bugarin (2006) \\
$\beta$ & Discount fator & 0.95 & $\frac{C}{Y}=0.65$ \\
$\sigma_{\varepsilon}^{2}$ & Variance & 0.045 & $G I N I=56$ \\
$\tau$ & Tax rate & 0.15 & $\frac{T}{\zeta}=9.41 \%$ \\
$\underline{b}$ & Borrowing Limit & 1.0 & $\underline{D e b t}=6 \%$ \\
$r$ & Interest rate & 0.039 & Berriel and Zilberman (2012) \\
$\theta_{1}, \theta_{2}, \theta_{3}, \theta_{4}$ & Households' fixed level of human capital & $\{1 ; 1.6 ; 3.2 ; 9\}$ & PNAD (2005) \\
\hline \hline
\end{tabular}

\footnotetext{
${ }^{14}$ We are considering a small open economy, therefore interest rates are exogenous.
} 


\subsection{2}

\section{Credit deepening}

We explore the response of our economy to a credit deepening. We consider an economy that at $t=0$ is in steady state with the borrowing limit $\underline{b}=1.0$. We then look at the effects of an unexpected shock at $t=1$ that permanently rises the borrowing limit to $\underline{b}^{\prime}=3.5$. The size of this shock is chosen to set the debt-to-GDP ratio at 16 percent after eight years. Therefore, we replicate the Brazilian credit deepening between 2004 and 2012.

Figure 2.1 shows the optimal values of consumption and assets as a function of households' assets holdings $(a)$ with $\theta_{1}=1$ and efficiency units of labor equals to $s=s_{5}$ in two steady states: before and after the credit shock. ${ }^{15}$

At high levels of $a$, household behavior is close to the permanent income hypothesis and the consumption function is almost linear in $a$. For lower levels of assets holdings, the consumption function is concave, as it is common in precautionary savings models. ${ }^{16}$ Also, the optimal values of assets holdings increase as $a$ increases.

After the credit shock, consumption is higher for all levels of assets holdings. Besides, their savings are reduced for all levels of $a$ because an increase in the borrowing limit reduces the precautionary motive in the economy.

Note that consumption response differs with the level of assets holdings. For households close to the borrowing constraint, precautionary motive is higher. Then, their consumption response to the credit shock is higher than households with high level of assets holdings.
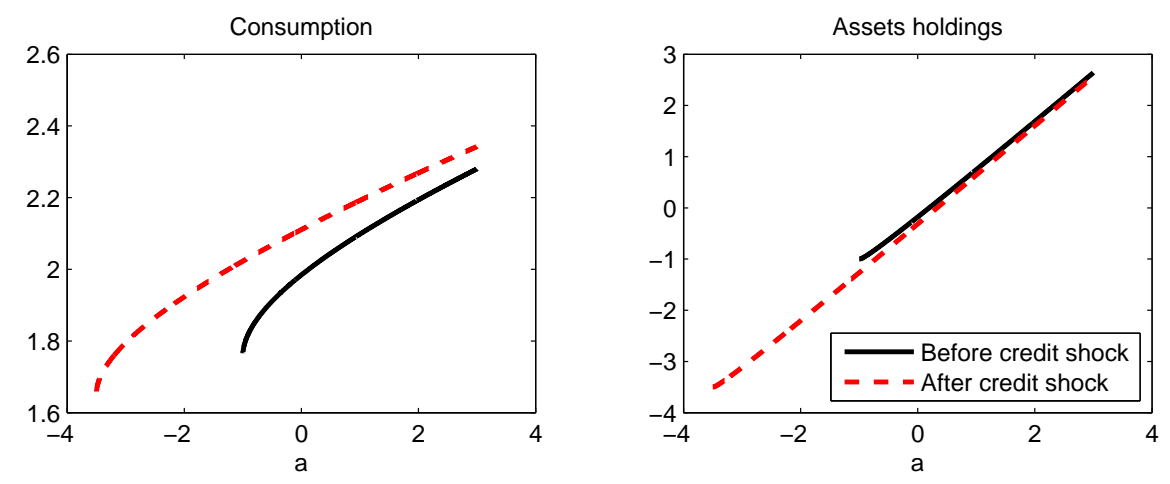

Figure 2.1: Optimal Consumption and Assets Holdings at $s=s_{5}$ and $\theta_{1}=1$ Benchmark.

\footnotetext{
${ }^{15}$ We choose this type of household as an example, but the interpretation in this section is valid for all other types and levels of efficiency units.

${ }^{16}$ See Carroll and Kimball (1996).
} 


\subsection{3}

\section{Case 1: Households' fixed level of human capital $\theta$}

In this section, we analyze the income inequality generated by the households' fixed level of human capital $\theta_{i}$. Specifically, we change this value for the households with the lowest fixed level of human capital, $\theta_{1}$. We are interested in generating economies with different levels of income inequality relative to the benchmark. Therefore, a higher (lower) value of $\theta_{1}$ reduces (increases) income inequality. Particularly, we set $\theta_{1}$ equal to 2.9 (0.7) to generate a Gini index of 53 (59).

Figure 2.2 shows the main results of this experiment which are in line with the empirical evidence found: ${ }^{17}$ the response of consumption per capita to a credit deepening is higher in economies with higher income inequality. At the top of this figure, we see that, in the economy with higher income inequality (lower $\theta_{1}$ ) than the benchmark, consumption per capita grows at the peak around 2.8 percent. However, in the other one with lower income inequality (higher $\theta_{1}$ ), consumption per capita at the peak grows 2 percent. In this result, the initial debt-to-GDP ratios (and all the paths) are different from the benchmark. Especially, in the economy with lower $\theta_{1}$, debt-to-GDP is above the benchmark in every year, which might influence this result. Then, we adjust the values of $\underline{b}$ and $\underline{b}^{\prime}$ to fit the before and after credit deepening ratios as in the benchmark economy (6 percent in 2004 and 16 percent in 2012, respectively). These results are shown in the bottom of the Figure 2.2 and the same effects as before persist, but the sizes are different from before. In the economy with higher inequality, consumption per capita at the peak grows around 2.5 percent and in the one with lower inequality, it grows at the peak 2.3 percent (close to the benchmark).

This result suggests that a decrease (increase) on the fixed level of human capital $\theta_{1}$ makes this group of households poorer (richer) than in the benchmark. This makes their assets policy, in the steady state, lower (higher) than the same group in the benchmark. As a result, there are more (less) households close to the borrowing constraint for this group. In an economy with more households close to the borrowing constraint, the effect of a credit deepening on consumption is higher.

In particular, in Table 2.4, we illustrate this fact by showing the share of households in debt in each economy, before the credit deepening, divided by their fixed level of human capital. These shares are from the calibration where all economies have the same initial debt-to-GDP ratio as in the benchmark.

\footnotetext{
${ }^{17}$ Consumption path is the ratio between consumption per capita in each period and consumption per capita in the first period.
} 

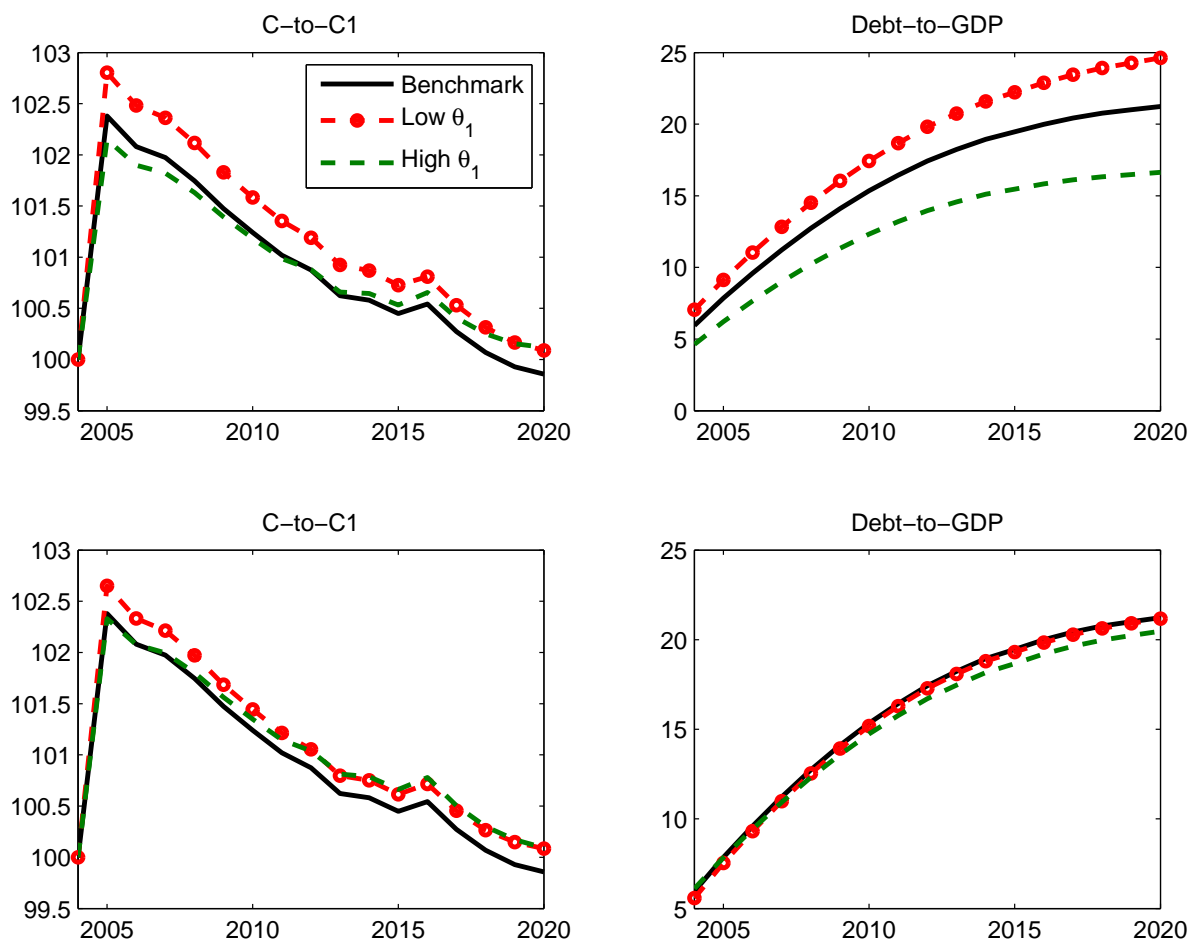

Figure 2.2: High and Low $\theta_{1}$

Note that in the economy with higher income inequality, there are more households in debt than the benchmark and the one with lower income inequality. As a result, wealth inequality is higher (lower) in the economy with higher (lower) income inequality than in the benchmark economy.

Table 2.4: Case 1 - Shares of households in debt at each economy divided by $\theta_{i}$

\begin{tabular}{cccc}
\hline \hline & Benchmark & High Ability & Low Ability \\
\hline & Debt $\%$ & Debt \% & Debt $\%$ \\
\hline$\theta_{1}$ & 67.2 & 46.1 & 85.6 \\
$\theta_{2}$ & 53.0 & 52.9 & 51.8 \\
$\theta_{3}$ & 45.2 & 45.0 & 44.5 \\
$\theta_{4}$ & 31.9 & 31.8 & 30.6 \\
\hline Total & 52.6 & 47.4 & 56.2 \\
\hline Income Gini & 56 & 52 & 59 \\
Wealth Gini & 84 & 81 & 86 \\
\hline \hline
\end{tabular}

\subsection{4}

\section{Case 2: Variance of the idiosyncratic risk $\sigma_{\varepsilon}^{2}$}

One of the sources of inequality inherent in our model is given by the variance of the idiosyncratic risk, $\sigma_{\varepsilon}^{2}$. This parameter determines the possible values of efficiency units of labor. The effect of a higher variance of the idiosyncratic risk on income inequality is twofold. First, a higher $\sigma_{\varepsilon}^{2}$ implies 
that the grid of possible values of $s_{t}$ has more extreme values, ${ }^{18}$ as a result income inequality increases. Second, a higher $\sigma_{\varepsilon}^{2}$ increases the precautionary motive in the economy, then households hold more assets. Note that households close to the borrowing constraint increase their savings more than the others, because their precautionary motive is higher. Consequently, income inequality decreases. We show that the first effect dominates.

We calibrate two different economies with different levels of income inequality relative to the benchmark. Specifically, we set $\sigma_{\varepsilon}^{2}$ equals to 0.055 (0.035) to generate a Gini index of 59 (53). After these economies are calibrated, we analyze the effect of a credit deepening on consumption per capita. Figure 2.3 presents the results for this experiment. At the top of this figure, we show the consumption paths without adjusting for the initial debt-to-GDP ratio. And at the bottom, we adjust the values of $\underline{b}$ and $\underline{b}^{\prime}$ to fit the before and after credit deepening debt-to-GDP ratios as in the benchmark economy (6 percent in 2004 and 16 percent in 2012, respectively).
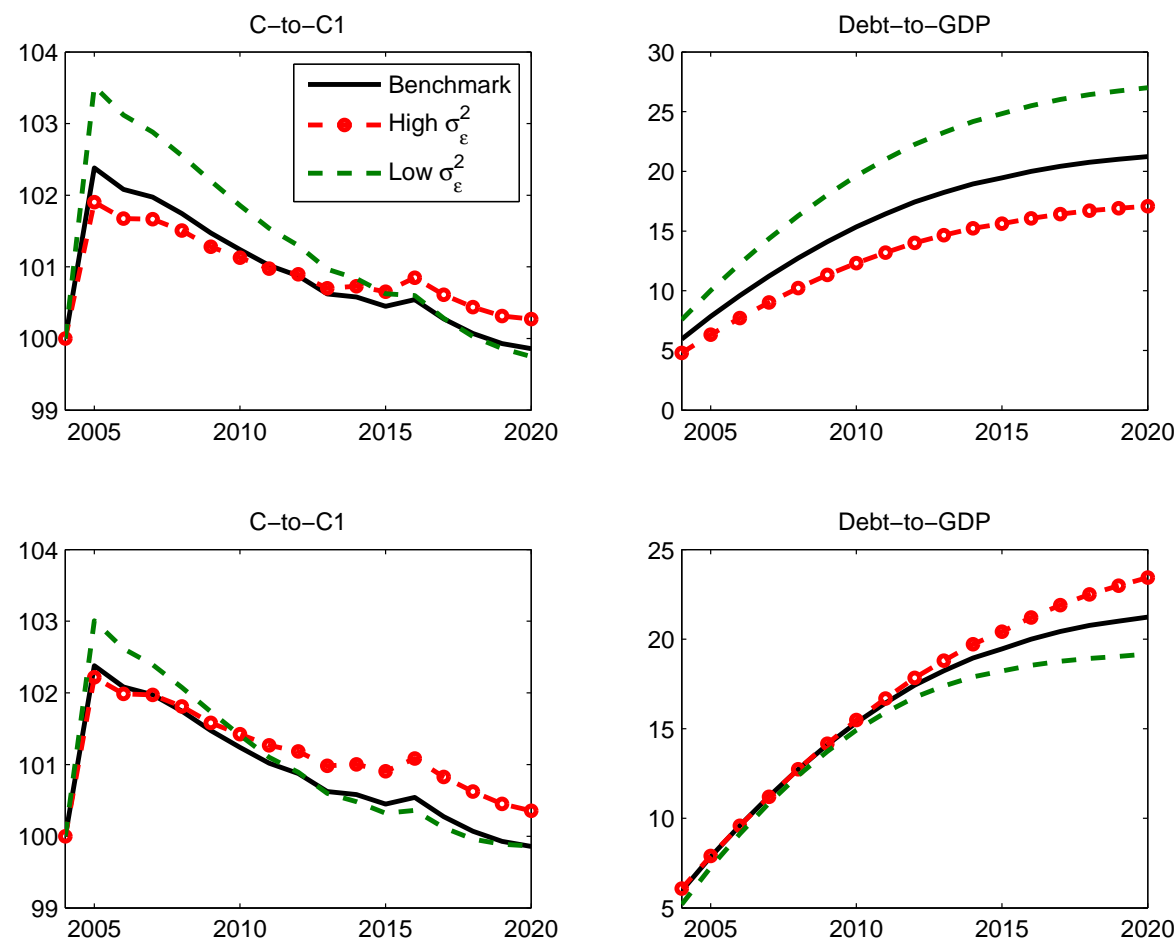

Figure 2.3: High and Low income uncertainty

Once the credit deepening process started via an increased permanent exogenous of $\underline{b}$, the economy with lower income inequality shows higher growth in consumption per-capita than the other with greater income inequality. In the first case, consumption growth at the peak is close to 3.5 percent, while in

\footnotetext{
${ }^{18}$ In Rouwenhorst (1995)'s algorithm, changes in $\sigma_{\varepsilon}^{2}$ modify the values of the states $s_{t}$ but the matrix of transition remains the same.
} 
the economy with higher inequality, it is around 2 percent, being located below the benchmark economy. Furthermore, when we fit the debt-to-GDP ratios as in the benchmark economy, the results were no different. Consumption growth at the peak for the economy with lower inequality is maintained above the benchmark, but with a lower value than before, 3 percent. But, in the economy with higher inequality, consumption growth at the peak is higher, 2.3 percent, close to the value on the benchmark economy.

These results show that in economies with higher inequality driven by more uncertainty on households' income, a credit deepening has a lower effect on consumption per capita than in an economy with lower inequality, driven by less uncertainty. This happens because, in our model, in an economy with high income uncertainty, households increase their precautionary savings, especially the ones close to the borrowing constraint. Therefore, in equilibrium, there are less households close to the borrowing constraint than in another economy with low income uncertainty.

In Table 2.5, we show this fact with the share of households in debt (negative assets holdings) in each economy before the credit deepening, divided by fixed level of human capital $\left\{\theta_{1}, \theta_{2}, \theta_{3}, \theta_{4}\right\}$. These shares are from the calibration where all economies have the same initial debt-to-GDP ratio as in the benchmark. There are less households in debt in all groups in a economy with higher inequality, explaining why the consumption response to a credit deepening is lower. Furthermore, there is a negative correlation between wealth and income inequality. This occurs because households have more assets holdings in an economy with higher income uncertainty, thus the wealth distribution becomes more equal (82) than the benchmark (84).

Table 2.5: Case 2 - Shares of households in debt at each economy divided by $\theta_{i}$

\begin{tabular}{cccc}
\hline \hline & Benchmark & High $\sigma_{\varepsilon}^{2}$ & Low $\sigma_{\varepsilon}^{2}$ \\
\hline & Debt \% & Debt \% & Debt $\%$ \\
\hline$\theta_{1}$ & 67.2 & 60.6 & 71.5 \\
$\theta_{2}$ & 53.0 & 49.5 & 58.2 \\
$\theta_{3}$ & 45.2 & 42.2 & 48.8 \\
$\theta_{4}$ & 31.9 & 28.1 & 42.0 \\
\hline Total & 52.6 & 48.5 & 57.6 \\
\hline Income Gini & 56 & 59 & 53 \\
Wealth Gini & 84 & 82 & 86 \\
\hline \hline
\end{tabular}




\subsection{5}

\section{Case 3: Fiscal policy $\{T, \tau\}$}

Another source of income inequality in our model is fiscal policy. ${ }^{19}$ There is a progressive tax on labor earnings that is used to fund a lump sum transfer that is uniform across all households. Consequently, inequality will be lower (higher) in economies with higher (lower) $\tau$ and $T$.

We calibrate two economies: one more and one less equal than the benchmark. In particular, we set $\tau=0.075(0.23)$ and $T=0.39$ (1.2) to generate a Gini index equal to 59 (53).
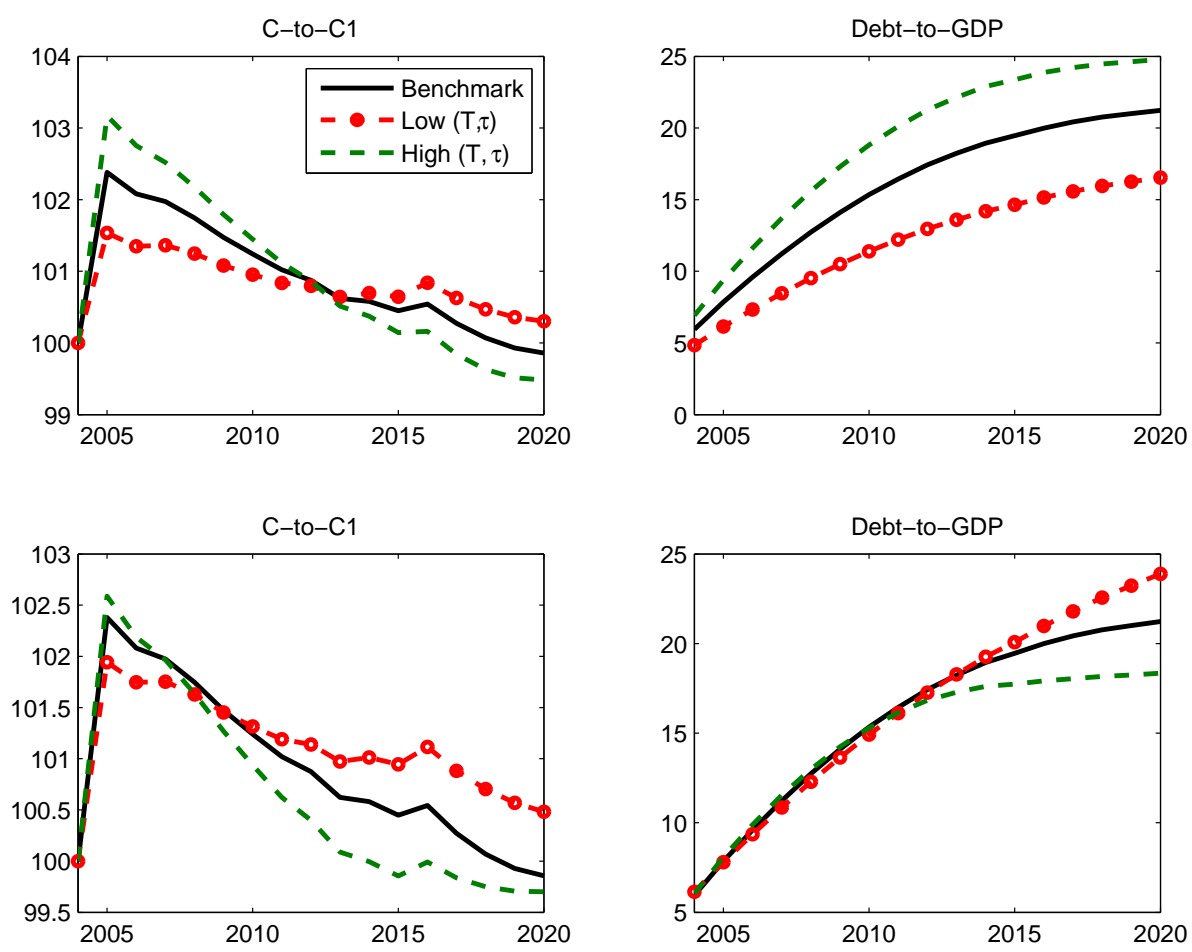

Figure 2.4: High and Low transfer and tax

Figure 2.4 shows our results. As in the case of the variance of idiosyncratic shock, the effect on consumption per capita of a credit deepening is higher in the economy with lower income inequality, i.e., with $T$ and $\tau$ higher. In this case, consumption growth at the peak is around to 3 percent, while in the economy with higher inequality, it is close to 1.5 percent, being located below the benchmark economy. Even when we adjust the values of $\underline{b}$ and $\underline{b}^{\prime}$ to fit the before and after credit deepening debt-to-GDP ratios as in the benchmark economy (6 percent in 2004 and 16 percent in 2012, respectively), the results persist. Especially, consumption per capita grows at the peak 2.5 percent in the economy with higher $T$ and $\tau$ and it grows at the peak 2 percent in other economy with lower $T$ and $\tau$.

\footnotetext{
${ }^{19}$ See subsection 2.3.1 (equation 2-6).
} 
Our results suggest that in economies with higher inequality due to lower $T$ and $\tau$, a credit deepening has a lower effect on consumption per capita than in a economy with lower inequality, due to higher $T$ and $\tau$. This happens because fiscal policy affects the precautionary motive in the economy. Thus, in an economy with lower $T$ and $\tau$, households increase their precautionary savings, in particular the ones close to the borrowing constraint. For this reason, there will be less households close to the borrowing constraint than in another economy with higher $T$ and $\tau$.

In Table 2.6, we illustrate this fact with the share of households in debt in each economy before the credit deepening, divided by fixed level of human capital $\left\{\theta_{1}, \theta_{2}, \theta_{3}, \theta_{4}\right\}$. These shares are from the calibration where all economies have the same initial debt-to-GDP ratio to the benchmark. Thus, there are less households in debt in all groups in a economy with higher inequality. Moreover, as in the case of the variance of idiosyncratic shock, there is a negative correlation between wealth and income inequality.

Table 2.6: Case 3 - Shares of households in debt at each economy divided by $\theta_{i}$

\begin{tabular}{cccc}
\hline \hline & Benchmark & High $\{T, \tau\}$ & Low $\{T, \tau\}$ \\
\hline & Debt $\%$ & Debt \% & Debt \% \\
\hline$\theta_{1}$ & 67.2 & 73.6 & 53.6 \\
$\theta_{2}$ & 53.0 & 62.0 & 45.7 \\
$\theta_{3}$ & 45.2 & 50.2 & 39.5 \\
$\theta_{4}$ & 31.9 & 41.1 & 28.1 \\
\hline Total & 52.6 & 60.0 & 44.5 \\
\hline Income Gini & 56 & 53 & 59 \\
Wealth Gini & 84 & 86 & 80 \\
\hline \hline
\end{tabular}

\section{5}

\section{Conclusion}

In this paper, we study the role of income income inequality in the association between credit deepening and consumption growth. We do so through two approaches. First, we use cross-country and panel estimations. Second, we use a workhorse Aiyagari model to check in which extent this theoretical approach can rationalize this empirical finding. Our results in the empirical part show that the association between consumption growth and credit expansion is stronger in countries with higher income inequality.

In theoretical part, we consider three sources of income inequality in our model: the variance of the idiosyncratic risk, fiscal policy and the households' fixed level of human capital. Our results suggests that when the source of 
income inequality comes from the households' lowest fixed level of human capital, our model can rationalize the empirical evidence. In the other cases, the opposite occurs. 


\section{3 \\ Impact of foreign shocks on small open economy: A FAVAR approach for Peru}

\section{1 \\ Introduction}

Understanding the effect of external shocks is relevant for small open economies, particularly in the current context of a greater degree of financial and commercial integration. The international developments and their impact on the domestic economy are becoming increasingly important for policy makers, considering that the macroeconomic outlook for small open economies can be strongly influenced by international developments through the impact of different types of shocks (international interest rate, foreign growth and commodities shocks).

In this paper, we examine the impact of US monetary policy shock and of the commodity price shock on a wide variety of macroeconomic variables of the Peruvian economy. This is the first study, to the best of our knowledge, that tries to provide an assessment of the dynamic effects of this kind of shocks using FAVAR methodology.

Understanding the effects of US monetary policy shocks is relevant in the current context, where an increase in interest rates are expected in the next years as the result of the reversion of monetary stimulus in US, after the dramatic reduction of the international interest rate of the Fed facing the international financial crisis of 2008.

In the case of Peru, studying these effects are especially important given the high degree of economic integration between Peru and US and considering that US disturbances have an important role in the determination of business cycles in Latin America, Canova (2005). Further, the persistent degree of dollarization of the Peruvian economy could amplify the effects of external shocks (see, e.g., Armas and Grippa, 2005; Castillo and Winkelried, 2010).

With respect the importance of commodity price shocks, we argue that these shocks are also relevant. The high degree of specialization of exports of Peruvian economy, leaves it vulnerable to fluctuations in the price of 
commodities, specially as gold or copper.

In this paper, we estimate a factor-augmented vector autoregressive (FAVAR) model to investigate the importance of external shocks on a small open economy. The FAVAR methodology exploits information contained in a large number of macroeconomic indicators and disaggregated variables.

FAVAR models were first developed by Bernanke et al. (2005), based on Stock and Watson (2002), and extended by Boivin and Giannoni (2008) and Mumtaz and Surico (2009) to analyse the effects of international shocks in open economy.

The FAVAR approach combines the standard VAR models with the Factor Analysis. It has the ability to process a vast amount of information through the reduction of the dimensionality of the data into a relatively small set of estimated factors. This methodology has many desirable properties. First, it uses a large data set of macroeconomic variables, similar those used by Central Banks. This property is important for adequately identifying monetary policy innovations. Bernanke et al. (2005) argue that the measurement of policy innovations is likely to be contaminated by limiting the analysis to a small number of macroeconomic variables. Second, the FAVAR approach provides impulse response functions for every variable within the information set.

In this work, we follow closely the methodology of Boivin and Giannoni (2008) considering two blocks: an external block that represents US economy characterized by a specific number of factors and the internal block which is also characterized by a number of factors that represent the Peruvian economy.

The main results are as follows. In response to contractive US monetary policy shock, Peruvian GDP growth, manufacturing sector growth and the inflation rate are reduced, whereas the domestic interest rate and exchange rate are increased. The variance decomposition shows that the nominal exchange rate present a greater variability to the foreign monetary shock compared to other domestic variables.

On the other hand, our findings reveal that higher commodity prices affect the Peruvian economy through a positive terms of trade shock, GDP growth, and increase the inflation. This evidence is consistent with the previous literature. (e.g. Castillo and Salas 2010).

The rest of the paper is organized as follows. The next section briefly describes the existing literature. Section 3.3 describes the methodology applied and the specification of the model. Section 3.4 shows the data description. Sections 3.5 and 3.6 present our main results and section 3.7 concludes. 


\section{2}

\section{Literature review}

The effects of external shocks on small open economies have been extensively discussed in the literature. Most of existing literature tried to disentangle the effects of internal and external shocks, both for developed economies and developing countries. (see, e.g., Canova and Marrinan, 1998; Canova 2005). In the case of analysis of external shocks, the literature focused on identifying the impacts of shocks: oil, international interest rate, international demand and commodity price.

The empirical evidence in developing countries is wide, Uribe and Yun (2006) find that US interest rate shocks are relevant in explaining the GDP of Latin American countries. On the other hand, Mackowiak (2007) finds evidence that the effects of interest rate shocks are less relevant than other external shocks.

Giovanni and Shambaugh (2008) find that external interest rate shocks have contractive effects on small open economies and that magnitude of the effects depend on the exchange rate regime. Raddatz (2007) finds that external shocks are less relevant compared with internal shocks. In the case of Peru, Castillo and Salas (2010) come upon that the terms of trade shocks can explain an important part of the business cycles. Much of the evidence showed in the literature is based on the estimation of VAR models. In this paper, we try to disentangle the effects of shocks on international interest rate shock and commodity price. We use a FAVAR model applied to the Peruvian economy.

Among the literature of FAVAR methodology applied to open economies, we can highlight two main papers. Mumtaz and Surico (2009) used a FAVAR model with sign restrictions and a bayesian VAR for studying the transmission of international interest shock on the UK economy, using a large panel of 17 countries. Boivin and Giannoni (2008) used a FAVAR to gauge the evolution of the impact of the international factors on the US economy.

Our work is closely related to these last two papers.

\section{3}

\section{Methodology}

\subsection{1}

\section{FAVAR}

The econometric framework used in this paper is based on the factoraugmented vector autoregression model (FAVAR) described in Stock and Watson (2002), Bernanke et al. (2005) and by Boivin and Giannoni (2008). We es- 
timate a FAVAR model using a two-step principal component approach, which permit us to explore the information from a large number of macroeconomic indicators, as well as from disaggregated data. The model consists of two blocks: an internal block represented by the Peruvian economy and an external block that represents the rest of the world. Especifically, we consider the foreign block the US economy. The information about the domestic and foreign economy is summarized by a number of unobserved and observed factors, where $F_{t}^{* u s}=\left[\begin{array}{ll}f_{i t}^{*} & R_{t}^{*}\end{array}\right]$ is the total number of factors for the foreign economy and $F_{t}^{p e r}=\left[\begin{array}{cc}f_{k t}^{p e r} & R_{t}^{p e r}\end{array}\right]$ is the total number of factors for the domestic economy. The joint dynamics of both $F_{t}^{* u s}$ and $F_{t}^{\text {per }}$ evolve according to the following transition equation:

$$
C_{t}=\Phi(L) C_{t-1}+v_{t}
$$

The equation of transition in your matrix notation is given by:

$$
\left[\begin{array}{l}
F_{t}^{* u s} \\
F_{t}^{\text {per }}
\end{array}\right]=\left[\begin{array}{ll}
\Phi_{11}(L) & \Phi_{12}(L) \\
\Phi_{21}(L) & \Phi_{21}(L)
\end{array}\right]\left[\begin{array}{l}
F_{t-1}^{* u s} \\
F_{t-1}^{\text {per }}
\end{array}\right]+\left[\begin{array}{l}
v_{t-1}^{*} \\
v_{t-1}
\end{array}\right]
$$

We consider an exogenous block structure in the transition equation. Therefore, we impose $\Phi_{12}(L)=0$ due to the assumption that the developments in Peruvian economy does not affect to the rest of the world at any horizons. While that following a US monetary policy shock, $\Phi_{21}(L)$, measures the extent to which US variables (factors) contribute to the transmission of the Peruvian monetary policy domestically.

The equation (3-1) is a standard VAR, except that the vectors of factors $f_{i t}^{*}$ and $f_{k t}^{p e r}$ are unobserved. We assume that the unobserved factors summarize the information contained in a large number of economic variables for each block, denoted by $X_{t}^{\text {per }}$ for the Peruvian economy and $X_{t}^{*}$ for the foreign economy. These vectors are of $N \times 1$ and $N^{*} \mathrm{x} 1$ respectively. The dynamics of each series domestic and foreign are assumed to relate to the state of the economy in each block according to the observation equations:

$$
\begin{gathered}
X_{t}^{*}=\Lambda^{*} F_{t}^{* u s}+e_{t}^{*} \\
X_{t}^{p e r}=\Lambda^{p e r} F_{t}^{p e r}+\Lambda^{* u s} F_{t}^{* u s}+e_{t}
\end{gathered}
$$

where $\Lambda^{*}$ is the matrix of factor loading and $N^{*} \mathrm{x} 1$ vector $e_{t}^{*}$ contains seriesspecific components that are uncorrelated with the common components $F_{t}^{* u s}$, and where $X_{t}^{\text {per }}$ is a $N \times 1$ vector of variables, $\Lambda^{\text {per }}$ and $\Lambda^{* u s}$ are $N \times(K+1)$, $N \times(I+1)$ matrices of factor loadings. Finally, the $N \times 1$ vector $e_{t}$ contains series-specific components that are uncorrelated with the common components.

Note that, the dynamics of the domestic series $X_{t}^{\text {per }}$ is a linear combin- 
ation of both the domestic factors $\left(F_{t}^{\text {per }}\right)$ as well as foreign factors $\left(F_{t}^{* u s}\right)$. In the equation (3-4) we considered that the dynamics of each domestic variable can be affected by the foreign factors because nothing prevents external factors affecting domestic variables. In addition, by the transition equation (3-1), we can see that there is a link between the foreign and domestic factors, then they can affect the domestic variables indirectly (or via a lag). Furthermore, we believe that if we do not consider external factors in the observed equation, we may underestimate the effect of external impulses on the domestic variables.

\subsection{2}

\section{Identification of the Foreign shock}

We are interested in studying the dynamic effect of a foreign monetary policy shock on a subset of macroeconomic series of the Peruvian economy. It is noteworthy that our efforts to identify the external monetary policy shock is given through the use of disaggregated information. For that aim, we impose only the minimum number of restrictions needed to identify the policy shock. More specifically, we use a recursive identification (Cholesky), implying that the foreign block is completely exogenous and does not react to Peruvian variables contemporaneously.

The variables in the FAVAR are ordered as follows:

$$
\left[\begin{array}{llll}
f_{i, t}^{*} & R_{t}^{*} & f_{k t}^{p e r} & R_{t}^{p e r}
\end{array}\right]^{\prime}
$$

where $\mathrm{i}=1, . . n_{\text {ext }}$ are the number of the foreign unobserved factors and $\mathrm{k}=1, . . \mathrm{n}$ are the number of the Peruvian unobserved factors.

Specifically, we assume that the federal funds rate $R_{t}^{*}$ is ordered last in the foreign block and the latent factors $f_{i, t}^{*}$ cannot respond to innovations in $R_{t}^{*}$ in the period of the shock. In the sequence, we order the domestic block in the same form as the foreign block. This is, the policy variable $R_{t}^{\text {per }}$ is ordered last, based on the assumption that the unobserved domestic factors $f_{k, t}^{p e r}$ do not react contemporaneously to domestic monetary policy shock. Thus, we obtain that the domestic economy is affected by all variables in the foreign block, both contemporaneously via the matrix that multiplies the identified shocks as well as dynamically, via the coefficients in the lags matrix.

\subsection{3}

\section{Estimation}

As in Bernanke et al.(2005) and by Boivin and Giannoni (2008), we estimate the FAVAR using a variant of a two-step principal component approach. 
In the first step, we extract principal components from $X_{t}^{\text {per }}$ and $X_{t}^{*}$ to obtain consistent estimates of the common factors. ${ }^{1}$ We represent the US economy by a number of unobserved factors extracted from a large panel of $N^{*}$ indicators, $X_{t}^{*}$, which contain important information about the fundamentals of the US economy. We include in the factors vector an observable measure of the monetary policy stance. We assume that the federal funds rate (FFR) is the instrument of policy for the US.

To identify the unobserved external factors we follow Boivin and Giannoni (2008). More specifically, we started from an initial estimate of $f_{t}^{*}$, denoted by $f_{t}^{*(0)}$ obtained the first $I$ principal components of $X_{t}^{*}$, we iterate through the following steps: (1) Regress $X_{t}^{*}$ on $f_{t}^{*(0)}$ and $R_{t}^{*}$ to obtain the coefficient on $R_{t}^{*}$, denote by $\widehat{\Omega}_{R}^{*(0)} ;(2)$ Compute $\widetilde{X}_{t}^{*(0)}=X_{t}^{*}-\widehat{\Omega}_{R}^{*(0)} R_{t}^{*}$; (3) Estimate $f_{t}^{*(1)}$ as the first $I$ principal components of $\widetilde{X}_{t}^{*(0)}$; (4) Repeat steps (1)-(3) multiple times until a certain convergence criterion is met. ${ }^{2}$ We do so because we are interested in uncovering the space spanned by the unobserved factors, but not caught by the foreign interest rate $R_{t}^{*}$. The total number of unobserved and observed foreign factors is represented by: $F_{t}^{* u s}=\left[\begin{array}{ll}f_{i t}^{*} & R_{t}^{*}\end{array}\right]$, where $i=1, . . n_{\text {ext }}$ is the number of the latent factors and $R_{t}^{*}$ is the federal funds rate which is the only observable factor.

The $\mathrm{k}$ domestic factors, $f_{k t}^{p e r}$, are extracted from the full panel of the Peruvian series. We follow the same strategy done for the foreign block.

In the second step, after the factors are estimated in both blocks, we estimate the equation (3-1) as a VAR. Finally, the response of each domestic series $X_{t}^{\text {per }}$ to a shock of foreign monetary policy in the transition equation (3-1) can be calculated using the estimated factor loadings and the equation (3-4). We estimated $\Lambda^{\text {per }}$ and $\Lambda^{* u s}$ for OLS, using $F_{t}^{\text {per }}$ and $F_{t}^{* u s}$ as regressors respectively.

\section{4}

Data

\subsection{1}

\section{The dataset for the domestic block}

Our dataset is comprised of 227 macroeconomic monthly series for the Peruvian economy, spanning from 2002:01 to 2008:08. It includes 77 macroeconomic indicators published by the Central Bank of Peru (CBP), containing

\footnotetext{
${ }^{1}$ Stock and Watson (2002) show that the principal components approach consistently recover the space spanned by the factors, $F_{t}^{* u s}$, when $N^{*}$ is large and the number of principal components used is at least as large as the true number of factors.

${ }^{2}$ More specifically, until $\widehat{\Omega}_{R}^{*(0)}$ converge.
} 
several measures of industrial production, interest rates, employment, exports, imports as well as other key macroeconomic and financial variables. These indicators contain useful information about the state of the economy for the appropriate identification of monetary policy and it could be interpreted as a better approach for measuring the information set used by the Central Bank of Peru in its policy decisions. We added also indicators of disaggregated prices not published by CBP. Specifically, we collected 150 series on CPI prices.

\subsection{2}

\section{The dataset for the foreign block}

The dataset consists of a panel of 629 monthly series for the US economy spanning the periods from 2002:01-2008:08 which cover a broad range of measures of real activity and income, employment, asset prices, interest rates and spreads, exchange rates, price indices and disaggregated series on personal consumption expenditures and producer prices indices. All the series are obtained from of Stock and Watson (2012) and Florido (2013).

We use a dataset containing 73 series of the major trading partners of Peru. This data contains information on real activity, inflation, money and interest rates for Germany, Japan, China, Switzerland, Chile, United States and Canada. All the series are obtained from central banks, OECD and IFS. ${ }^{3}$

We are also interested in investigating how the commodity price shock affect the Peruvian economy. Thus we use a dataset of 53 commodities prices, to generate the factor that represents the variability this set. All the series are obtained from IFS.

Finally, in both the cases we take the log differences of all series with the exception of interest rates. The data is then standardized. Further we end our sample in August 2008 due to the zero lower bound problem that was observed in the federal funds rate (FFR) at the end of 2008, as a result of the financial crisis.

${ }^{3}$ Where OECD is The Organisation for Economic Co-operation and Development, and IFS is International Financial Statistics. 


\section{5 \\ Results for the foreign block US economy}

\subsection{1}

\section{The effect of foreign monetary policy shock}

In this section, we describe our main results that are shown in Figure 3.1. The figure shows the impulse response functions (IRFs) of a selection of key macroeconomic variables from Peru to an unexpected increase of 25 basis points of the federal funds rate. The solid line indicates the estimated response. The upper and lower dashed lines plotted in each graph represent 90 percent bootstrap confidence intervals based on 1,000 bootstrap samples. ${ }^{4}$ We use two lags that were chosen using information criteria tests.

We used the Bai and $\mathrm{Ng}$ (2002) criterion in the determination of the number of factors. ${ }^{5}$ Considering they not are decisive, we limit the number of unobservable factors to four for the foreign block and three for domestic block. We did this to strike a balance between the variance of the original series, which is explained by the principal components, and the need to maintain a parsimonious VAR. In total, our VAR model is composed of three external factors and an observed factor and two domestic factors and an observed factor. We estimate a VAR model with seven variables. ${ }^{6}$ To test whether our results are altered when the number of factors is changed, we consider two alternative specifications with six and eight factors. These results are reported in Figures 4.1 and 4.2 in the appendix. We find that changing the number of factors does not change qualitatively the nature of our main results.

The figure 3.1 shows that an unexpected increase in the short term interest rate in the foreign block has a negative effect on real activity in the Peruvian economy. More specifically, the output growth significantly declines but only recovers at about 10 months. Other measures of economic activity also tend to decrease, like the manufacturing and mining sectors. These last reactions indicate that the international transmission of monetary shocks exists in the case of Peru. The FAVAR methodology uncovers such response which may have been ignored by a VAR methodology. This is because VAR uses

${ }^{4}$ As the two-step approach implies the presence of "generated regressors" in the second step. The covariance matrix obtained at this stage tends to underestimate the actual uncertainty. Thus in order to construct an accurate confidence intervals on the impulse response functions reported below, we implement a bootstrap procedure, based on Kilian (1998) used also by Bernanke et al. (2005).

${ }^{5}$ This criterion proposed a set of selection criteria to choose the estimated number of factors, that are generalizations of the BIC and AIC criteria.

${ }^{6} \mathrm{We}$ consider as the observable factor the federal fund rate for the foreign block and the interbank interest rate (as proxy of reference policy rate) for the domestic block. 
a limited number of variables, which usually means including only a general measure of production.

The decline in production is also consistent with raising domestic interest rates. Equally consistent with higher interest rates is the decline in money as measured by monetary base growth. Further, inflation shows a small decrease on impact, following the domestic monetary tightening. Hence, interest rates are a channel of transmission of foreign monetary shock. On the other hand, on impact, the exchange rate depreciates and there is a reduction of international reserves, this finding could be consistent with the foreign market intervention of the Central Bank trying to reduce the depreciation pressure in exchange rate market. The increase in the foreign interest rate improves slightly the exports growth, the terms of trade and reduces the import growth, but these effects are not significant.
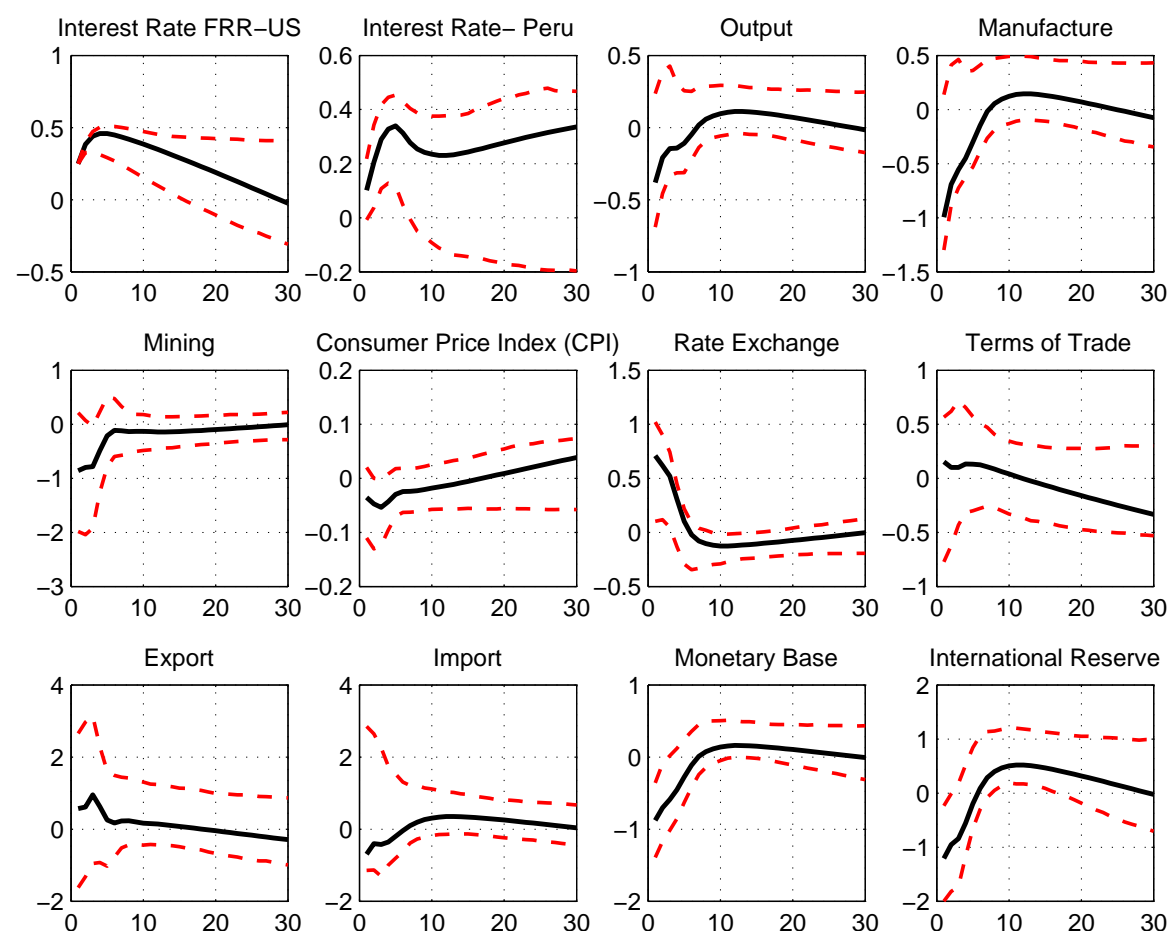

Figure 3.1: Shows the response of the Peruvian economy to a 25 basis points increase of foreign monetary shock IRF. The variables are represented in monthly growth (percentage change), except for the interest rates.

\subsection{2}

\section{Variance Decomposition: Contribution of foreign monetary shock to variance of the common component.}

Another exercise in the analysis of standard VAR is the variance decomposition. This consists of determining the fraction of the forecasting error of a variable, at a given horizon, that is attributable to a particular shock. In 
the context of FAVAR approach, this suggests a potentially more appropriate decomposition, where the relative importance of a structural shock is assessed only to the portion of the variable explained by the common factors. More formally, this variance decomposition for $X_{t}^{\text {per }}$ can be expressed as:

$$
\frac{\Lambda_{i} \operatorname{var}\left(C_{t+k}^{p e r}-\widehat{C}_{t+k} \mid v_{t}^{*}\right) \Lambda_{i}^{\prime}}{\Lambda_{i} \operatorname{var}\left(C_{t+k}^{p e r}-\widehat{C}_{t+k \mid t}\right) \Lambda_{i}^{\prime}}
$$

where $\Lambda_{i}$ is the ith line of $\Lambda=\left[\Lambda^{\text {per }}, \Lambda^{* u s}\right], C_{t+k}^{\text {per }}=\left(F_{t}^{\text {per' }}, F_{t}^{* u s^{\prime}}\right)^{\prime}$ and $\frac{\operatorname{var}\left(C_{t+k}^{p e r}-\widehat{C}_{t+k} \mid v_{t}^{*}\right)}{\operatorname{var}\left(C_{t+k}^{p e r}-\widehat{C}_{t+k \mid t}\right)}$ is the standard VAR variance decomposition based on eq (3-1).

Table 3.1 reports the results for the variance decomposition of the main variables in our analysis. The first column reports the $R^{2}$ of the common component (domestic and foreign factors) and the second column shows the contribution of a external monetary policy shock to the variance of the forecast of the common component, at the 30-month horizon.

Table 3.1: Variance Decomposition at the 30-month horizon.

\begin{tabular}{ccc}
\hline Variables & $R^{2}$ & $\begin{array}{c}\text { Variance } \\
\text { Decomposition }\end{array}$ \\
\hline GDP & 0.2454 & 0.0263 \\
Manufacture & 0.2425 & 0.0622 \\
Employment & 0.3953 & 0.0268 \\
Rate Exchange $(\$ / S /)$. & 0.5462 & 0.1338 \\
Export & 0.0498 & 0.0322 \\
Import & 0.0681 & 0.0189 \\
Terms of Trade & 0.1721 & 0.0325 \\
Inflation & 0.1690 & 0.0432 \\
Money Base & 0.3181 & 0.1145 \\
International Reserves & 0.3341 & 0.0668 \\
\hline
\end{tabular}

We see that the foreign policy shock explains between $2 \%$ and $13 \%$ of the forecast variance of principle variables. In particular, the foreign policy shock explains $2.63 \%$ of GDP growth and $4.32 \%$ the inflation, whereas $11.45 \%$ on the monetary base growth and $13.38 \%$ of the depreciation of the exchange rate. This suggests that the foreign monetary policy shock has greater participation in the volatility of the exchange rate and a small contribution in the variability of output, employment and external indicators, such as exports and imports. This evidence shows that the foreign monetary shock would affect mainly financial variables more than real variables.

Looking at the $R^{2}$ of the common component we can observe that the factors explain a sizeable fraction of the variables principles. Specifically, the most aggregated measures of real economic activity growth, GDP with to 
$24.54 \%$ and employment growth with to $39.53 \%$. This shows that most of the fluctuations in Peruvian GDP are reasonably determined by this combination of factors. On the other hand, the correlation with the terms trade and the import and export growth is particularly low with $17.21 \%, 6.81 \%$ and $4.98 \%$ respectively. Note that the $R^{2}$ of common component is low for the export and import growth, that implies that we should be prudent when using the impulse response estimates for these variables.

\subsection{3}

\section{Commodity Price Shock}

The Peruvian economy, as a large exporter of a broad range of commodities, is exposed to changes in the external economic environment. This section attempts to quantify the potential impact of commodity price shocks on the Peruvian economy. This question is of particular interest today, in light of the increased uncertainty about the global economic outlook. It is noteworthy that changes in commodity prices affect Peru through its terms of trade, as well as through demand for Peruvian export.

With such objective in mind, we generate a factor that represents the behavior of the common pattern of commodity prices. ${ }^{7}$ We follow Jeffrey (2006) and place the factor that represent commodities last in the foreign block, i.e., after of the federal fund rate,

$$
\left[\begin{array}{lllll}
f_{i, t}^{*} & R_{t}^{*} & f_{t}^{c o} & f_{k t}^{p e r} & R_{t}^{p e r}
\end{array}\right]^{\prime}
$$

where $\mathrm{i}=1, . . n_{\text {ext }}$ are the number of the foreign factors, $f^{c o}$ is the factor that represent the set commodity price and $\mathrm{k}=1, . . n$ are the number of the Peruvian factors.

We estimate the FAVAR with four factors for the foreign economy, including the factor that represented the commodities and the observable factor for the US. The number of domestic factors is the same as in our main results. ${ }^{8}$

The response of the Peruvian economy to a one standard deviation change in commodity prices is shown in Figure 3.2 (log changes). There is a slight increase in monthly GDP growth, monthly manufacturing growth, and mining in response to this shock. The increase in the output growth can be explained by an increase in the growth of exports, and to a lesser extent to the growth of the mining products and the increase in the terms of trade. This latter increase occurs in spite of the exchange rate appreciation, which in turn increases the imports growth. Overall, our results are consistent with previous studies

\footnotetext{
${ }^{7}$ We generate one factor of a set of commodities prices published by the IMF.

${ }^{8}$ Our results remain robust, when we consider 4 domestic factors and 5 foreign factors.
} 
analyzing shock of terms of trade in developing economies (e.g. Castillo and Salas 2010).

Finally, a positive commodity price shock leads to some inflation pressures, as the CPI inflation rate jumps weakly. This impact could be deeper, but is contained by the appreciation of the exchange rate. The interest rate increases slightly, as a response of the monetary authority to the rise in inflation.
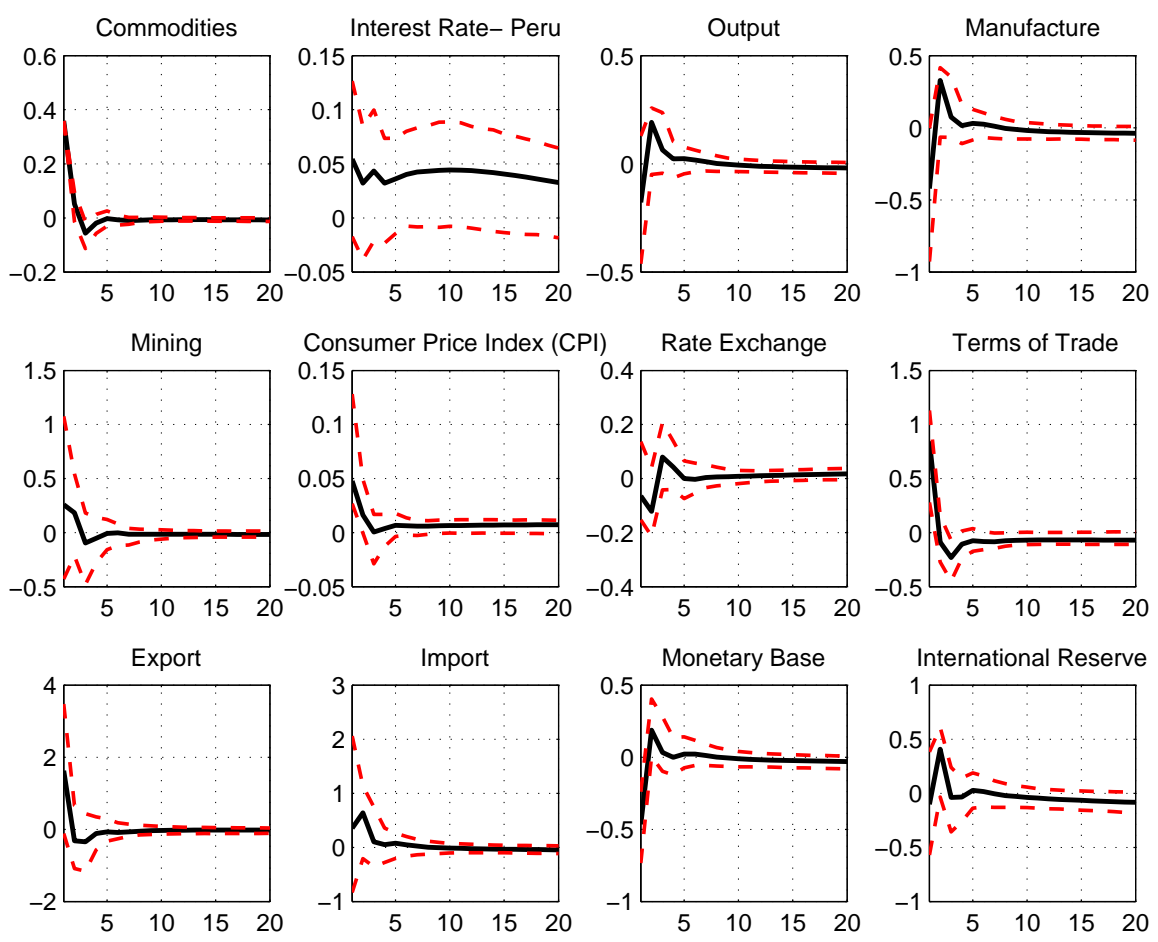

Figure 3.2: Shows the response of the Peruvian economy to a shock of one standard deviation in the commodity factor - IRF. The variables are represented in monthly growth (percent change), except the interest rates.

\section{6}

\section{Results for the foreign block with the major trading partners of Peru}

In this section we consider as foreign block the major trading partners of Peru. Specifically we extract international factors from a large panel of data covering 7 countries that are the major trading partners of Peru. ${ }^{9}$ We follow Mumtaz and Surico (2009) to identify the $J$ external factors. We assume that the foreign economy consists of four factors, $F_{t}^{* s o c}=$ $\left[\begin{array}{cccc}\Delta Y_{t}^{*} & \pi_{t}^{*} & \Delta M_{t}^{*} & F R_{t}^{*}\end{array}\right]$ where $\Delta Y_{t}^{*}$ represents international comovements in real activity of the major trading partners, $\pi_{t}^{*}$ denotes an international inflation factor, $\Delta M_{t}^{*}$ is an international money factor, and $F R_{t}^{*}$ denotes comove-

${ }^{9}$ See subsection 3.4.2. 
ments in international interest rates. Specifically, we extract the international real activity factor from all international real activity series of the set to date of the major trading partners of Peru. The other international factors are also identified in the same form. As in the previous case, we analyze the impact of two foreign shocks on the Peruvian economy. In particular, foreign interest rate and commodity price shocks. The results are show in the figures 3.3 and $3.4 .^{10}$ In the case of a commodity shock, we consider that the commodity factor is placed in the foreign block, first in the ordering, and it is assumed to be able to affect simultaneously all the variables of trading partners as well as Peruvian variables.

In figure 3.3, we present the dynamic effects of an unexpected increase in foreign interest rate. The signs of the impact are in line with the results in figure 3.1. The GDP growth and manufacturing growth show a fall in the first period, while the response of the mining growth shows a slight fall. Further, on impact, the exchange rate depreciates that in turn increases the exports growth and decreases the imports growth and the reserves. The inflation responds with a significant fall at around the third period. Finally, in this case, the monetary policy reaction is delayed, increasing the interest rate only in the third period.
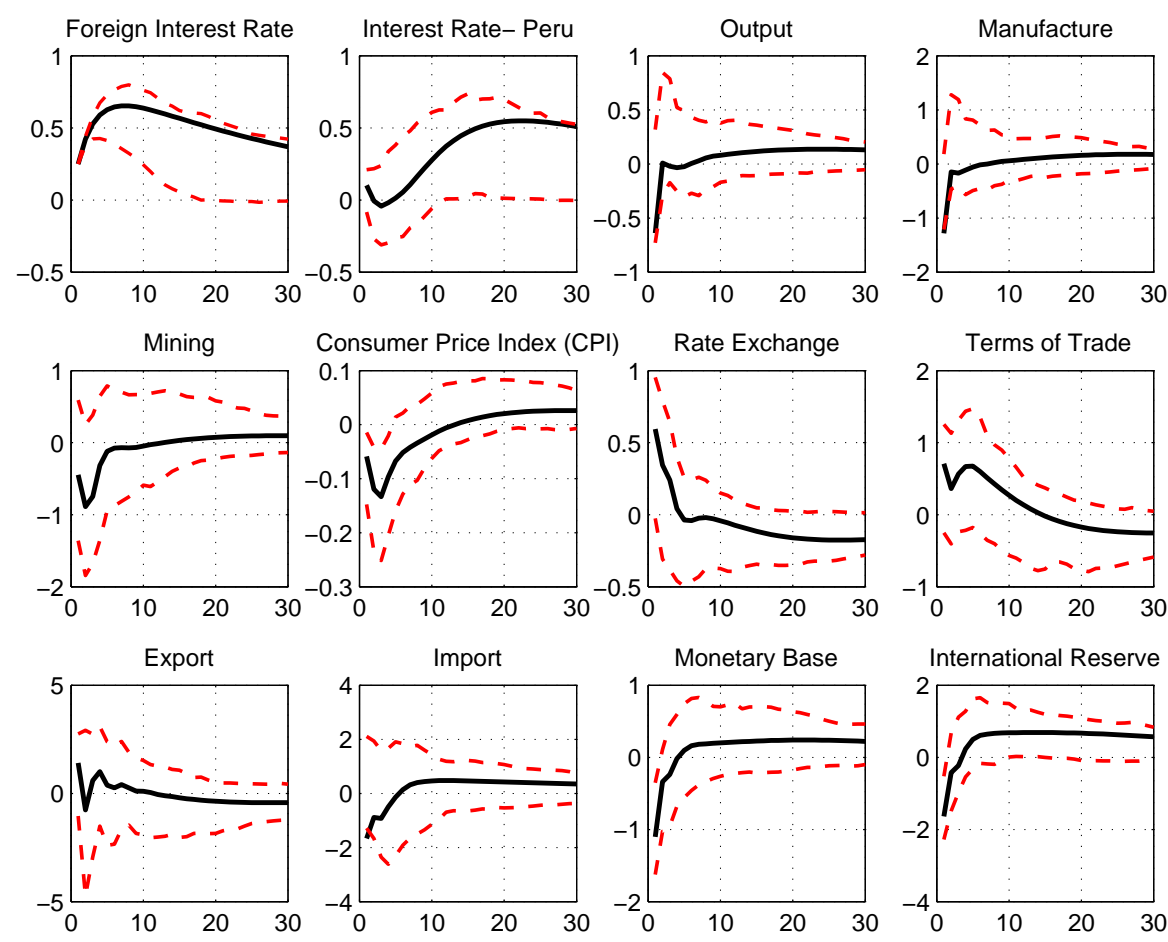

Figure 3.3: Shows the response of the Peruvian economy to a 25 basis points increase of foreign monetary shock IRF. The variables are represented in monthly growth (percentage change), except for the interest rates.

${ }^{10}$ The only difference of this section with respect to the above is the identification of factors. The rest of the methodology remains the same. 
The estimated impulse responses of a set of macroeconomic variables to a commodity price shock are reported in Figure 3.4. The responses are broadly in line with the dynamic effects obtained in the previous case, when we consider the foreign block the US. In particular, we find evidence of a positive impact on output growth, manufacture growth and mining growth, while, the net exports and the terms trade improve. Note also that the policy rate increase is consistent with the increase in the inflation.
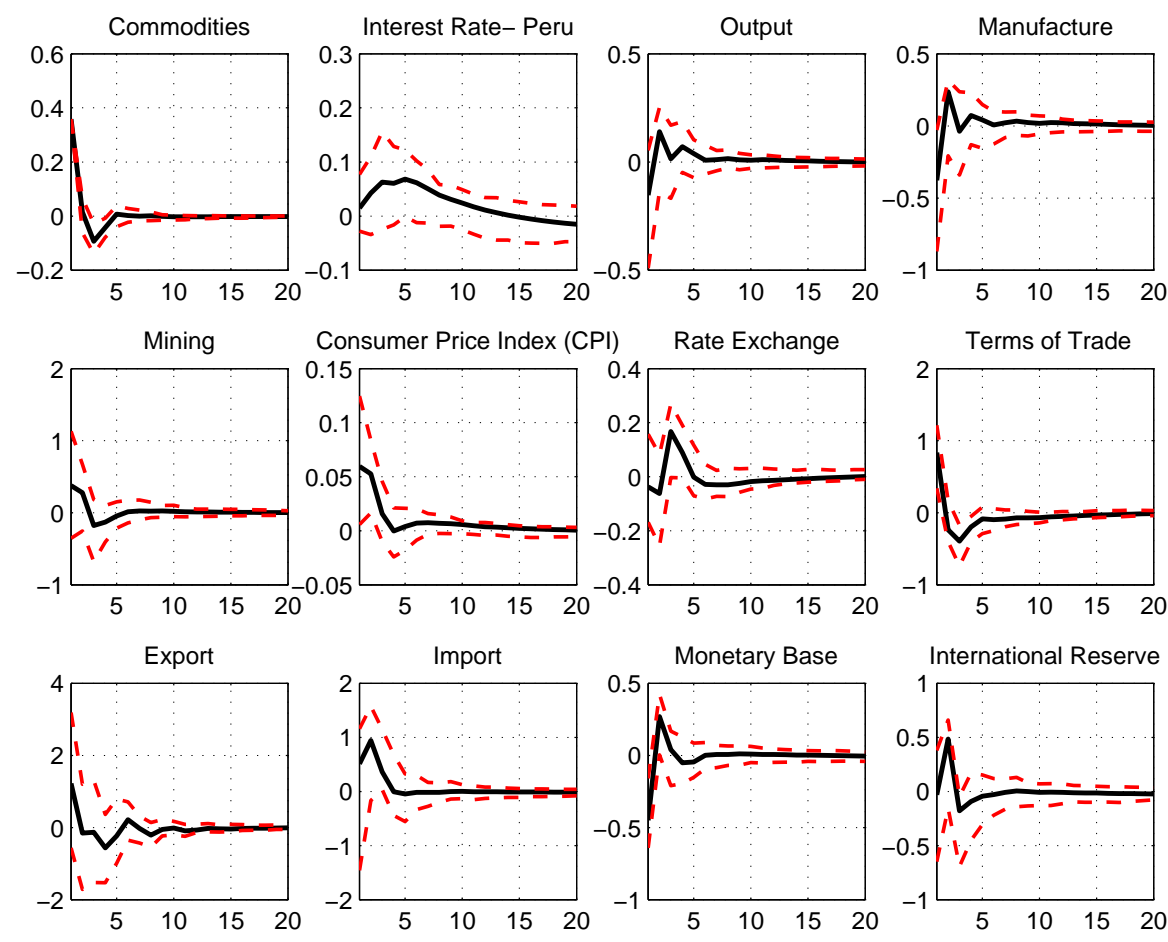

Figure 3.4: Shows the response of the Peruvian economy to a shock of one standard deviation in the commodity factor - IRF. The variables are represented in monthly growth (percent change), except the interest rates.

\section{7}

\section{Conclusions}

In this paper, we study how different external shocks affect the Peruvian economy. We do so by using a Factor-Augmented Vector Autoregressive (FAVAR) model. This methodology allows us to explore a large set of macroeconomic data, both foreign and domestic. This methodology is used to trace out the effect of different shocks on the economy in a rich data environment, which allows to improve some weaknesses of traditional VAR models. We find that a positive international interest rate shock has contractive and significant effects, it reduces GDP and inflation rate and generates an exchange rate depreciation, an increase of the domestic interest rate and a reduction of international reserves. In the case of commodity price shock, we find that its effects 
are consistent with the previous literature in which a positive shocks expands GDP, net exports and inflation rate. 


\section{References}

AGHION, P.; BOLTON, P. A Theory of Trickle-Down Growth and Development. Review of Economic Studies, v.64, p.151-172, 1997.

BAI, J.; SERENA, Ng. Determining the Number of Factors in Approximate Factor Models. Quarterly Journal of Economics, v. 120, p.387- 422, 2002.

AIYAGARI, R. Uninsured Idiosyncratic Risk and Aggregate Saving. Quarterly Journal of Economics, v. 109, n.3, p. 659-84, 1994.

ALESINA, A.; RODRIK, D. Distributive Politics and Economic Growth. The Quarterly Journal of Economics, v. 109, n.2, p.465-490, 1994.

ARMAS, A.;GRIPPA, F. targeting Inflation in a Dollarized Economy: The Peruvian Experience. Inter-American Development Bank,working paper, n. 538, 2005.

BANERJEE, A.V.; NEWMAN, A.F.Occupational Choice and the Process of Development. Journal of Political Economy, v. 101, n.2, p. 274-298, 1993.

BERNANKE, B.; GERTLER, M. Agency costs, net worth and business fluctuations. American Economic Review, v.79, n.1, p.14-31, 1989.

BERNANKE, B.; GERTLER, M., GILCHRIST, S. The financial accelerator in a quantitative business cycle framework. In: Handbook of Macroeconomics, v. 1, edited by Taylor, J., Woodford, M, 1999.

BERNANKE, B,; BOIVIN, J.; ELIASZ, P. Measuring the Effects of Monetary Policy: A Factor augmented Vector Autoregressive (FAVAR) Approach. Quarterly Journal of Economics, v. 120, n.1, p. 387-422, 2005.

BERRIEL, T.; ZILBERMAN, E. Targeting the poor: A macroeconomic analysis of cash transfer programs. Working Paper, 2011.

BEWLEY, T. The Permanent Income Hypothesis: A Theoetical Formulation. Journal of Economics Theory, v.16, n.2, p.252-292, 1977. 
BOIVIN, J.; GIANONNI, M. Global forces and monetary policy effectiveness. NBER working paper, n. 13736, 2008.

CANOVA, F. The Transmission of US Shocks to Latin America. Journal of international Economics, v.78, p. 341-361, 2005.

CANOVA, F.; DE NICOLÓ, G. Stock returns, term structure, inflation, and real activity: an international perspective. Macroeconomic Dynamics, v.4, p. 343-372, 2000.

CANOVA, F.; DE NICOLÓ, G. On the source of cyclical fluctuations in the G-7. Journal of International Economics, v.59, p. 77-100, 2003.

CANOVA, F.; MARRINAN, J. Sources and propagation of international output cycles. Journal of International Economics, v.37, p. 22-54, 1998.

CALVO,G.A. Staggered prices in a utility-maximizing framework. Journal of Monetary Economics, v.12, n.3, p. 383-398, 1983.

CARVAlHO, F.; CASTRO, M.; COSTA, S. Traditional and Matter-of-fact Financial Frictions in a DSGE Model for Brazil: The Role of Macroprudential Instruments and Monetary Policy. Banco Central do Brasil Working Paper, n. 336, 2013.

CARROLL, C.D. The Method of Endogenous Gridpoints for Solving Dynamic Stochastic Optimization Problems. Economics Letters, v.91, n.3, p. 312-320, 2006 .

CARROLL, C.D.; KIMBALL, M.S. On the Concavity of the Consumption Function. Econometrica, v. 64, n.4, p. 981-92, 1996.

CASTILLO, P.; SALAS, J. The terms of trade as drivers of economic fluctuations in developing economies: an empirical study. Centro de Estudios Monetarios Latinoamericanos (CEMLA), premio de Banca Central Rodrigo Gómez , 2010.

CURDIA V.; WOODFORD, M. Credit Spreads and Monetary Policy. Journal of Money, Credit and Banking, v.42, p. 3-35, 2010.

DA SILVA, M.F.; ANDRADE, J.; SILVA, G.; BRANDI, V. Financial frictions in the Brazilian banking system: a DSGE model with Bayesian estimation. Working Paper, 2012. 
DE CASTRO, M.; GOUVEA, S.; MINELlA, A.; SANTOS, R.; SOUZASOBRINHO, N. SAMBA: Stochastic Analytical Model with a Bayesian Approach. Banco Central do Brasil, Working Paper, n.239, 2011.

FERNANDEZ-VILLAVERDE, J.; KRUEGUER, D. Life-Cycle Consumption, Debt Constraints and Durable Goods. Macroeconomic Dynamics, v.15, n.5, p. 725-770, 2004.

FORBES, K. J. A Reassessment of the Relationship between Inequality and Growth. American Economic Review, v.90, n.4, p. 869-887, 2000.

FLORIDO, P. G. Cost channel of monetary policy: Evidence from FAVAR on disaggregated data. Dissertation Puc-Rio, 2013.

FRENCH, E. The effects of health, wealth, and wages on labour supply and retirement behavior. Review of Economic Studies, v. 72, n.2, p. 395-427, 2005 .

GALOR, O.; ZEIRA, J. Income Distribution and Macroeconomics. Review of Economic Studies, v. 60, n.1, p. 35-52, 1993.

GERALI, A.; NERI, S.; SESSA, L.; SIGNORETTI, F. Credit and Banking in a DSGE Model of the Euro Area. Journal of Money, Credit and Banking, v. 42 , p. 107-141, 2010.

GERTLER, M.; KIYOTAKI, N. Financial Intermediation and Credit Policy in Business Cycle Analysis. In: Handbook of Monetary Economics, v. 3, edited by Friedman, B., Woodford, M, 2010.

GIOVANNI, J.; SHAMBAUGH, J. The impact of foreign interest rates on the economy:The role of the exchange rate regime. Journal of Applied Econometrics, v. 20, p. 229-251, 2008.

GUERRIERI, L.; IACOVIELLO, M. Collateral Constraints and Macroeconomic Asymmetries. Working paper, 2013.

GUERRIERI, V.; LORENZONI, G. Credit Crises, Precautionary Savings and the Liquidity Trap. Working Paper, 2011.

IACOVIELLO, M. House Prices, Borrowing Constraints, and Monetary Policy in the Business Cycle. American Economic Review, v. 95, n. 3, p. 739-764, 2005 . 
IACOVIELLO, M.; NERI, S. Housing market spillovers: evidence from an estimated DSGE model. American Economic Journal: Macroeconomics, v. 2, p. 125-164, 2010.

JUSTINIANO. A; PRIMICERI, G.; TAMBALOTTI, A. Household Leveraging and Deleveraging. NBER Working Paper, n. 18941, 2014.

JEFFREY, A.,F. The Effect of Monetary Policy on Real Commodity Prices. NBER working paper, n. 12713, 2006.

KANCZUK, F. Um Termômetro para as Macro-Prudenciais. Revista Brasileira de Economia, v. 67, n. 4, p. 739-764, 2013.

KIYOTAKI, N.; MOORE, J. Credit Cycles. Journal of Political Economy, v.105, n. 2, p. 211-248, 1997.

KILIAN, L. Small-Sample Confidence Intervals for Impulse Response Functions. Review of Economics and Statistics, v. 80, n. 2, p. 218-230, 1998.

LIU, Z.; WANG, P.; ZHA, T. Land-Price Dynamics and Macroeconomic Fluctuations. Econometrica, v. 81, n. 3, p. 1147-1184, 2013.

MENDOZA, E. Credit, Prices, and Crashes: Business Cycles with a Sudden Stop. In: Preventing Currency Crises in Emerging Markets, edited by Edwards, S.,Frankel, J, 2002.

MAĆKOWIAK, B. External shocks, U.S. monetary policy and macroeconomic fluctuation in emerging markets. Journal of Money Economics, v. 54, p. 2512-2520, 2007.

MUMTAZ, H.; SURICO, P. The transmission of international shocks: A factoraugmented VAR approach. Journal of Money, Credit and Banking, v. 41, p. 71-100, 2009.

PAES, N.; BUGARIN, M. Parâmetros Tributários da Economia Brasileira. Estudos Econômicos, v. 36, n. 4, p. 699-720, 2006.

PERUGINI, C.; HOLSCHER, J.; COLLIE, S. Inequality, credit expansion and financial crises. MPRA Working paper, n. 51336, 2013.

PERSSON, T.; TABELLINI, G. Is Inequality Harmful for Growth?. American Economic Association, v. 84, n. 3, p. 600-621, 1994. 
RADDATZ, C. Are external shocks responsible for the instability of output in low-income countries?. Journal of Development Economics, v. 84, p. 155-187, 2007.

RAVALliOn, M. Why Don't We See Poverty Convergence?. American Economic Review, v. 102, n. 1, p. 504-523, 2012.

RAVALLION, M. Inequality is Bad for the Poor. In J. Micklewright and S. Jenkins (eds.), Inequality and Poverty Re-Examined. Oxford University Press, 2007.

RAVALLION, M. Growth, Inequality and Poverty: Looking Beyond Averages. World Development, v. 29, n. 11, p. 1803-1815, 2001.

RÍOS-RULL, J.V. Computation of Equilibria in Heterogeneous Agent Models. Computational methods for the study of dynamic economies, v. 238264, 1999.

ROUWENHORST, K.G. Asset pricing implications of equilibrium business cycle models. In: Cooley, T.F. (Ed.), Frontiers of Business Cycle Research. Princeton University Press, Princeton, n. 294-330, 1995.

STOCK, J.; WATSON, M. Macroeconomic forecasting using diffusion indexes. Journal of Business Economics and Statistics, v. 20, n. 2, p. 147-162, 2002 .

STOCK, J.; WATSON, M. Generalized Shrinkage Methods for Forecasting Using Many Predictors. Journal of Business and Economic Statistics, v. 30, n. 4, p. 481-493, 2012.

TAUCHEN, G. Finite State Markov Chain Approximations to Univariate and Vector Autoregressions. Economic Letters, v. 20, n.2, p. 177-181, 1986.

URIBE, M.; YUE, V.,Z. Country spreads and emerging markets: who drives whom?. Journal of international Economics, v. 69, p. 6-36, 2006.

WINKELRIED,D.; CASTILLO,P. Dollarization persistence and individual heterogeneity. Journal of International Money and Finance, v. 29, n. 8, p. 1596-1618, 2010.

WUlfF, G. S.; OCTÁviO, R. O. Classificação e Análise das Despesas Públicas Federais pela Ótica Macroeconômica. Working Paper-IPEA, n. $1485,2010$. 
A

\section{Results for the foreign block U.S. economy}

The number of foreign factors used are three (two unobserved factors and FFR). The number of domestic factors used are three (two unobserved factors and the interbank interest rate).
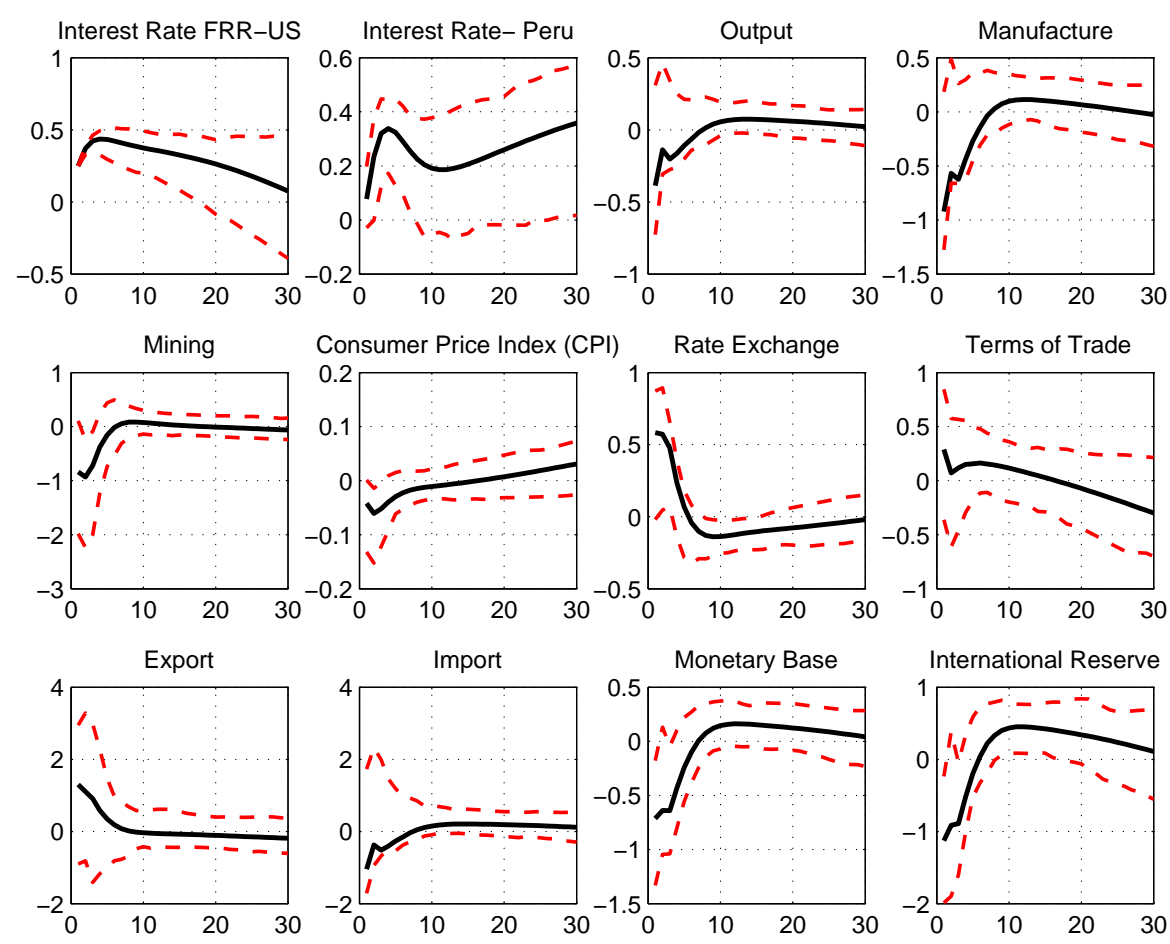

Figure 4.1: Shows the response of the Peruvian economy to a 25 basis points increase of foreign monetary shock IRF. The variables are represented in monthly growth (percent change), except the interest rates. 
The number of foreign factors used are four (three unobserved factors and FFR). The number of domestic factors used are four (three unobserved factors and the interbank interest rate).
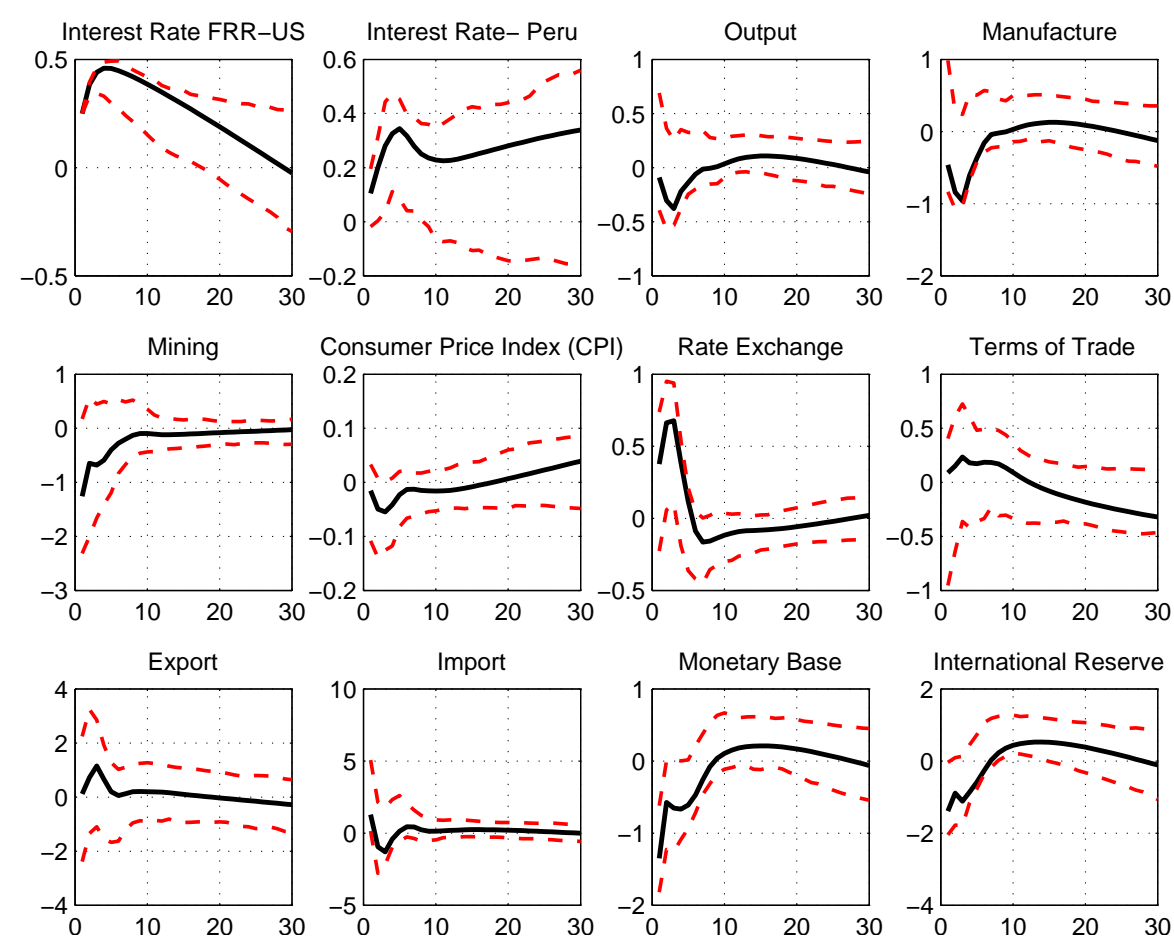

Figure 4.2: Shows the response of the Peruvian economy to a 25 basis points increase of foreign monetary shock IRF. The variables are represented in monthly growth (percent change), except the interest rates. 